Prepared in cooperation with the City of Albuquerque, the Albuquerque Metropolitan Arroyo Flood Control Authority, the New Mexico Department of Transportation, and the University of New Mexico

\title{
Summary of Urban Stormwater Quality in Albuquerque, New Mexico, 2003-12
}

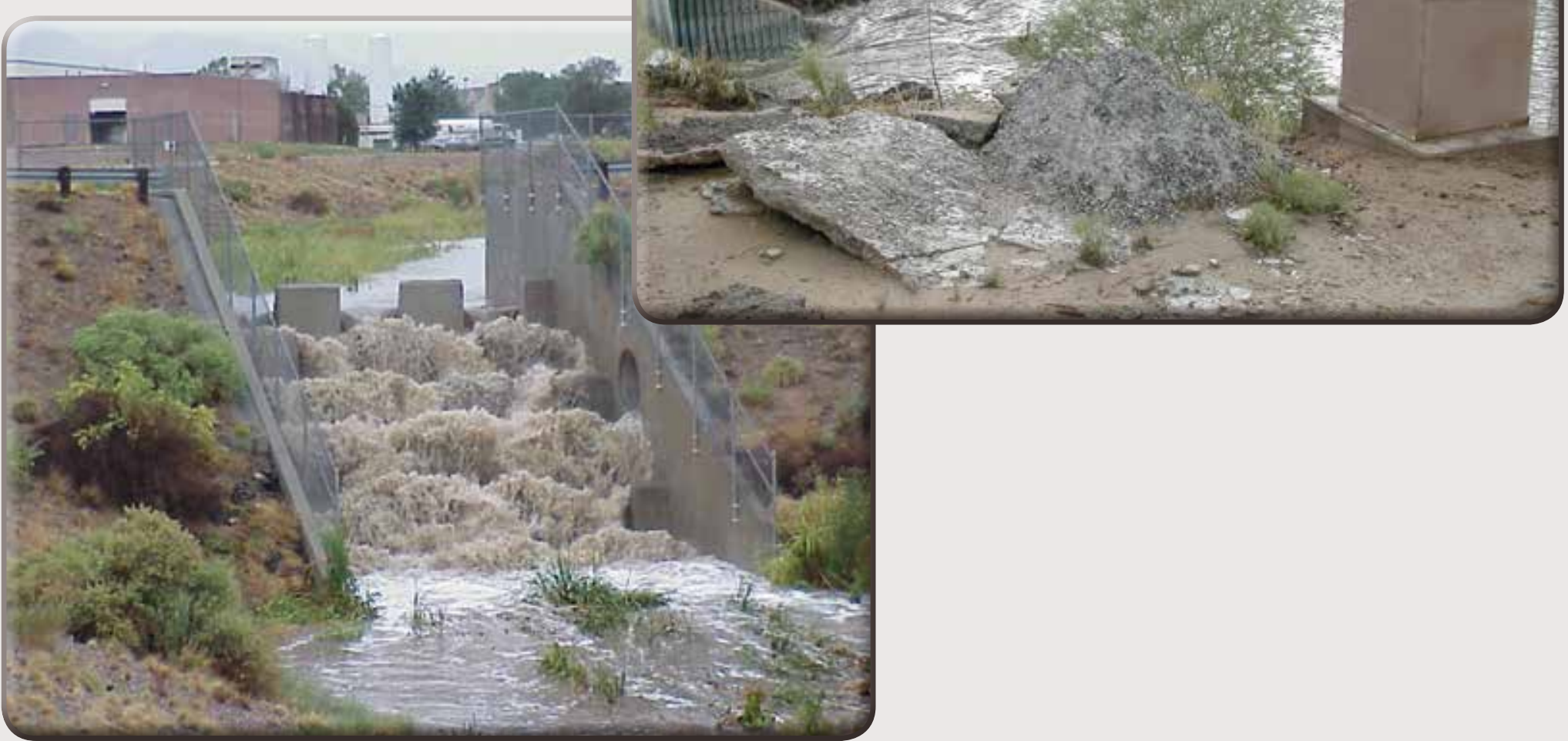

Scientific Investigations Report 2015-5006 


\section{Cover:}

Top, July 2006 stormwater flow; view oriented upstream at streamgage 083299375, Mariposa Diversion of San Antonio Arroyo site (photograph by Todd M. Kelly, retired, U.S. Geological Survey).

Bottom, September 2002 stormwater flow; view oriented upstream at streamgage 08329870, Bear Arroyo at Jefferson Street site (photograph by Todd M. Kelly, retired, U.S. Geological Survey). 


\section{Summary of Urban Stormwater Quality in Albuquerque, New Mexico, 2003-12}

By Erik F. Storms, Gretchen P. Oelsner, Evan A. Locke, Michael R. Stevens, and Orlando C. Romero

Prepared in cooperation with the City of Albuquerque, the Albuquerque

Metropolitan Arroyo Flood Control Authority, the New Mexico Department of Transportation, and the University of New Mexico

Scientific Investigations Report 2015-5006 


\title{
U.S. Department of the Interior SALLY JEWELL, Secretary
}

\section{U.S. Geological Survey \\ Suzette M. Kimball, Acting Director}

\author{
U.S. Geological Survey, Reston, Virginia: 2015
}

For more information on the USGS - the Federal source for science about the Earth, its natural and living resources, natural hazards, and the environment—visit http://www.usgs.gov or call 1-888-ASK-USGS.

For an overview of USGS information products, including maps, imagery, and publications, visit http://www.usgs.gov/pubprod/.

Any use of trade, firm, or product names is for descriptive purposes only and does not imply endorsement by the U.S. Government.

Although this information product, for the most part, is in the public domain, it also may contain copyrighted materials as noted in the text. Permission to reproduce copyrighted items must be secured from the copyright owner.

Suggested citation:

Storms, E.F., Oelsner, G.P., Locke, E.A., Stevens, M.R., and Romero, O.C., 2015, Summary of urban stormwater quality in Albuquerque, New Mexico, 2003-12: U.S. Geological Survey Scientific Investigations Report 2015-5006, 48 p., http://dx.doi.org/10.3133/sir20155006.

ISSN 2328-0328 (online) 


\section{Acknowledgments}

The authors thank and acknowledge the valuable contributions of time, resources, and technical guidance from the many individuals who assisted in this study, including Kathy Verhage, Kevin Daggett, and Roland Penttila of the City of Albuquerque and Karen Stearns, John Kelly, and Jerry Lovato of the Albuquerque Metropolitan Arroyo Flood Control Authority.

Field and technical assistance was provided by Scott Anderholm, Jack Veenhuis, Todd Kelly, Michael Jimenez, and Kent Blankenship of the U.S. Geological Survey. 



\section{Contents}

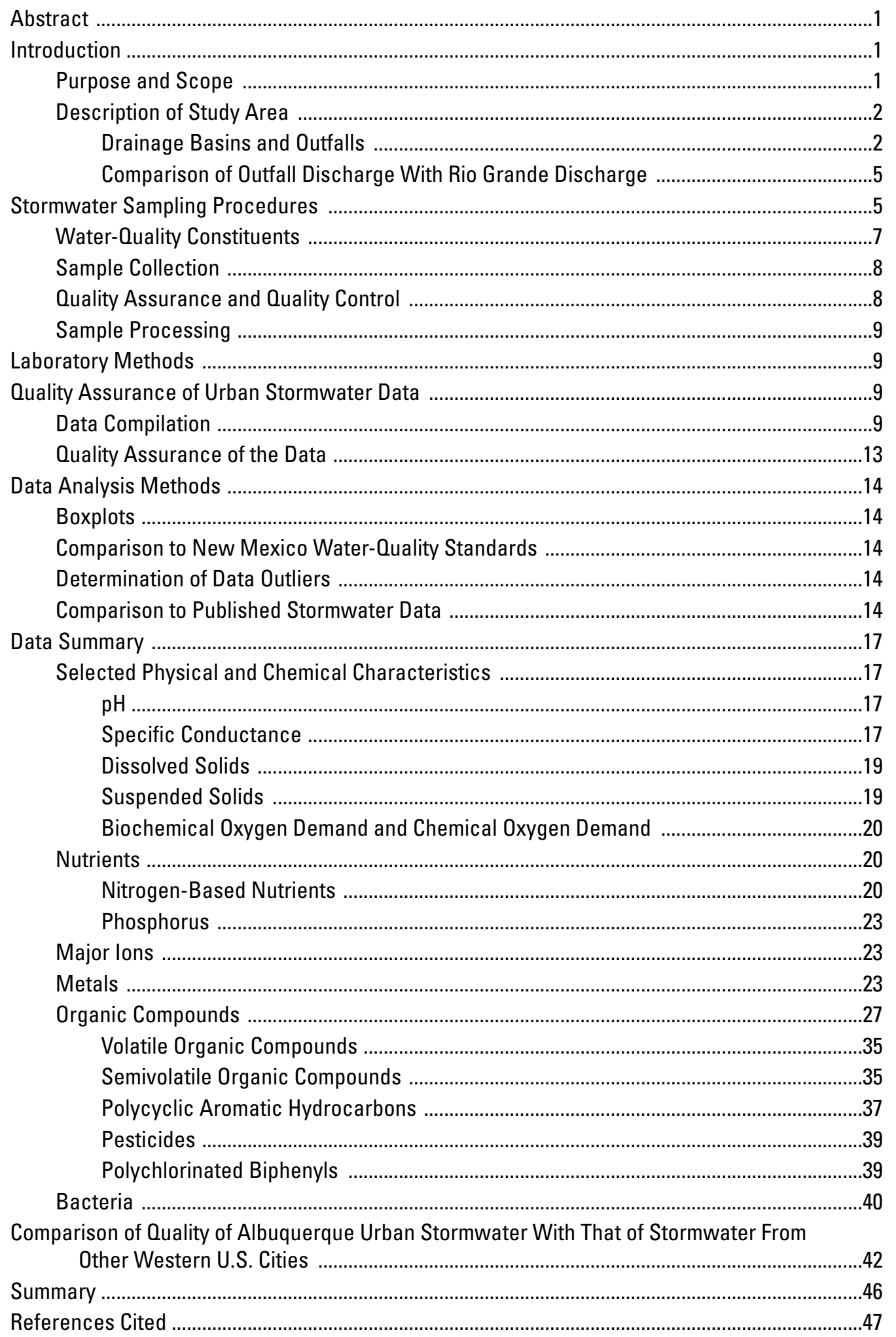


Appendixes [available at http://pubs.usgs.gov/sir/2015/5006/]

1. Standard Operating Procedures for the Albuquerque Bernalillo County Water Utility Authority Laboratory

2. Standard Operating Procedures for the State of New Mexico Department of Health Scientific Laboratory Division

3. Stormwater-Quality Data Collected in the Albuquerque Metropolitan Area, New Mexico, 2003-12

\section{Figures}

1. Map showing the study area and locations of sampling sites and streamgages, Albuquerque metropolitan area, New Mexico, 2003-12

2. Boxplots showing dissolved solids concentrations in urban stormwater samples from five outfalls in the Albuquerque metropolitan area, New Mexico, 2003-12

3. Boxplots showing suspended solids concentrations in urban stormwater samples from five outfalls in the Albuquerque metropolitan area, New Mexico, 2003-12

4. Boxplots showing biochemical oxygen demand concentrations in urban stormwater samples from five outfalls in the Albuquerque metropolitan area, New Mexico, 2003-12

5. Boxplots showing total phosphorus concentrations in urban stormwater samples from five outfalls in the Albuquerque metropolitan area, New Mexico, 2003-12

6. Boxplots showing chloride concentrations in urban stormwater samples from five outfalls in the Albuquerque metropolitan area, New Mexico, 2003-12

7. Boxplots showing sulfate concentrations in urban stormwater samples from five outfalls in the Albuquerque metropolitan area, New Mexico, 2003-12

8. Boxplots showing dissolved aluminum concentrations in urban stormwater samples from five outfalls in the Albuquerque metropolitan area, New Mexico, 2003-12

9. Boxplots showing ethyl methyl ketone concentrations in urban stormwater samples from five outfalls in the Albuquerque metropolitan area, New Mexico, 2003-12

10. Boxplots showing trihalomethane concentrations in urban stormwater samples from five outfalls in the Albuquerque metropolitan area, New Mexico, 2003-12

11. Boxplots showing xylene concentrations in urban stormwater samples from five outfalls in the Albuquerque metropolitan area, New Mexico, 2003-12

12. Boxplots showing bis(2-ethylhexyl) phthalate concentrations in urban stormwater samples from five outfalls in the Albuquerque metropolitan area, New Mexico, 2003-12

13. Boxplots showing di-n-butyl phthalate concentrations in urban stormwater samples from five outfalls in the Albuquerque metropolitan area, New Mexico, 2003-12

14. Boxplots showing diethyl phthalate concentrations in urban stormwater samples from five outfalls in the Albuquerque metropolitan area, New Mexico, 2003-12

15. Boxplots showing fluoranthene concentrations in urban stormwater samples from five outfalls in the Albuquerque metropolitan area, New Mexico, 2003-12

16. Boxplots showing phenanthrene concentrations in urban stormwater samples from five outfalls in the Albuquerque metropolitan area, New Mexico, 2003-12 
17. Boxplots showing pyrene concentrations in urban stormwater samples from five outfalls in the Albuquerque metropolitan area, New Mexico, 2003-12

18. Boxplots showing pentachlorophenol concentrations in urban stormwater samples from five outfalls in the Albuquerque metropolitan area, New Mexico, 2003-12

19. Boxplots showing Escherichia coli bacteria densities in urban stormwater samples from nine outfalls in the Albuquerque metropolitan area, New Mexico, 2003-12

20. Graphs showing comparison of median concentrations for selected constituents in urban stormwater samples at outfalls in the Albuquerque metropolitan area, New Mexico, with median concentrations for selected constituents in stormwater for other selected Western U.S. cities, 2003-12

\section{Tables}

1. Site information for stormwater outfalls in the Albuquerque metropolitan area, New Mexico, 2003-12

2. Annual number of flow days at sampled outfalls with U.S. Geological Survey streamgages, Albuquerque metropolitan area, New Mexico, 2003-12

3. Annual volume of stormwater discharge at sampled outfalls with U.S. Geological Survey streamgages, Albuquerque metropolitan area, New Mexico, 2003-12

4. Annual stormwater discharge contributions of the North Diversion Channel to the total annual flow of the Rio Grande as measured at the Rio Grande at Albuquerque streamgage, Albuquerque metropolitan area, New Mexico, 2003-12

5. Water-quality constituents analyzed in urban stormwater samples from outfalls, Albuquerque metropolitan area, New Mexico, 2003-12

6. List of water-quality constituents, U.S. Environmental Protection Agency analytical test methods, and analytical laboratories used for constituent analysis of urban stormwater samples from outfalls, Albuquerque metropolitan area, New Mexico, 2003-12

7. Concentration screening criteria for constituents in urban stormwater runoff samples from outfalls in the Albuquerque metropolitan area, New Mexico, 2003-12.

8. Statistical summary of concentrations for physical and chemical constituents in urban stormwater samples from five outfalls in the Albuquerque metropolitan area, New Mexico, 2003-12

9. Statistical summary of concentrations for nutrients in urban stormwater samples from five outfalls in the Albuquerque metropolitan area, New Mexico, 2003-12

10. Statistical summary of concentrations for major ions in urban stormwater samples from five outfalls in the Albuquerque metropolitan area, New Mexico, 2003-12 ..........25

11. Statistical summary of concentrations for dissolved metals in urban stormwater samples from five outfalls and the Rio Grande at Albuquerque in the Albuquerque metropolitan area, New Mexico, 2003-12

12. Statistical summary of concentrations for detected volatile organic compounds in urban stormwater samples from five outfalls in the Albuquerque metropolitan area, New Mexico, 2003-12

13. Statistical summary of concentrations for detected semivolatile organic compounds in urban stormwater samples from five outfalls in the Albuquerque metropolitan area, New Mexico, 2003-12 
14. Statistical summary of concentrations for detected polycyclic aromatic hydrocarbons in urban stormwater samples from five outfalls in the Albuquerque metropolitan area, New Mexico, 2003-12

15. Statistical summary of concentrations for detected pesticides in urban stormwater samples from five outfalls in the Albuquerque metropolitan area, New Mexico, 2003-12

16. Organic constituents not detected in urban stormwater samples from five outfalls in the Albuquerque metropolitan area, New Mexico, 2003-12

17. Total concentrations for polychlorinated biphenyl congeners in urban stormwater samples from five outfalls and the Rio Grande upstream from the North Diversion Channel in the Albuquerque metropolitan area, New Mexico, 2011-12

18. Statistical summary of bacteria densities in urban stormwater samples from nine outfalls in the Albuquerque metropolitan area, New Mexico, 2003-12

19. Comparison of median concentrations for selected constituents in urban stormwater samples at outfalls in the Albuquerque metropolitan area with median concentrations for selected constituents in stormwater for selected Western U.S. cities, New Mexico, 2003-12

\section{Conversion Factors}

Inch/Pound to International System of Units

\begin{tabular}{|c|c|c|}
\hline Multiply & By & To obtain \\
\hline \multicolumn{3}{|c|}{ Length } \\
\hline inch (in.) & 2.54 & centimeter $(\mathrm{cm})$ \\
\hline foot $(\mathrm{ft})$ & 0.3048 & meter $(\mathrm{m})$ \\
\hline mile (mi) & 1.609 & kilometer $(\mathrm{km})$ \\
\hline \multicolumn{3}{|c|}{ Area } \\
\hline acre & 4,047 & square meter $\left(\mathrm{m}^{2}\right)$ \\
\hline square mile $\left(\mathrm{mi}^{2}\right)$ & 2.590 & square kilometer $\left(\mathrm{km}^{2}\right)$ \\
\hline \multicolumn{3}{|c|}{ Volume } \\
\hline gallon (gal) & 3.785 & liter $(\mathrm{L})$ \\
\hline acre-foot (acre-ft) & 1,233 & cubic meter $\left(\mathrm{m}^{3}\right)$ \\
\hline \multicolumn{3}{|c|}{ Flow rate } \\
\hline cubic foot per second $\left(\mathrm{ft}^{3} / \mathrm{s}\right)$ & 0.02832 & cubic meter per second $\left(\mathrm{m}^{3} / \mathrm{s}\right)$ \\
\hline \multicolumn{3}{|c|}{ International System of Units to Inch/Pound } \\
\hline Multiply & By & To obtain \\
\hline \multicolumn{3}{|c|}{ Volume } \\
\hline liter $(\mathrm{L})$ & 33.82 & ounce, fluid (fl. oz) \\
\hline liter (L) & 2.113 & $\operatorname{pint}(\mathrm{pt})$ \\
\hline liter (L) & 1.057 & quart (qt) \\
\hline liter (L) & 0.2642 & gallon (gal) \\
\hline liter $(\mathrm{L})$ & 61.02 & cubic inch $\left(\mathrm{in}^{3}\right)$ \\
\hline \multicolumn{3}{|c|}{ Mass } \\
\hline $\operatorname{gram}(\mathrm{g})$ & 0.03527 & ounce, avoirdupois (oz) \\
\hline milligram (mg) & $3.527 \times 10^{-5}$ & ounce, avoirdupois (oz) \\
\hline microgram $(\mu \mathrm{g})$ & $3.527 \times 10^{-8}$ & ounce, avoirdupois (oz) \\
\hline picogram (pg) & $3.527 \times 10^{-14}$ & ounce, avoirdupois (oz) \\
\hline
\end{tabular}


Temperature in degrees Celsius $\left({ }^{\circ} \mathrm{C}\right)$ may be converted to degrees Fahrenheit $\left({ }^{\circ} \mathrm{F}\right)$ as follows:

${ }^{\circ} \mathrm{F}=\left(1.8 x^{\circ} \mathrm{C}\right)+32$

Temperature in degrees Fahrenheit $\left({ }^{\circ} \mathrm{F}\right)$ may be converted to degrees Celsius $\left({ }^{\circ} \mathrm{C}\right)$ as follows:

${ }^{\circ} \mathrm{C}=\left({ }^{\circ} \mathrm{F}-32\right) / 1.8$

Vertical coordinate information is referenced to the North American Vertical Datum of 1988 (NAVD 88).

Horizontal coordinate information is referenced to the North American Datum of 1983 (NAD 83).

Altitude, as used in this report, refers to distance above the vertical datum.

Specific conductance is given in microsiemens per centimeter at 25 degrees Celsius $(\mu \mathrm{S} / \mathrm{cm}$ at $\left.25^{\circ} \mathrm{C}\right)$.

Concentrations of chemical constituents in water are given in either milligrams per liter (mg/L) or micrograms per liter $(\mu \mathrm{g} / \mathrm{L})$.

\section{Abbreviations}

\begin{tabular}{|c|c|}
\hline ABCWUA & Albuquerque Bernalillo County Water Utility Authority \\
\hline AMAFCA & Albuquerque Metropolitan Arroyo Flood Control Authority \\
\hline BOD & biochemical oxygen demand \\
\hline $\mathrm{cfu} / 100 \mathrm{~mL}$ & colony-forming units per 100 milliliters \\
\hline COD & chemical oxygen demand \\
\hline EPA & U.S. Environmental Protection Agency \\
\hline HH-OO & human health-organism only \\
\hline IQR & interquartile range \\
\hline MAD & median absolute deviation \\
\hline MST & microbial source tracking \\
\hline $\mathrm{MPN} / 100 \mathrm{~mL}$ & most probable number per 100 milliliters \\
\hline MS4 & Municipal Separate Storm Sewer System \\
\hline NMAC & New Mexico Administrative Code \\
\hline NM WQS & New Mexico water-quality standard \\
\hline NPDES & National Pollutant Discharge Elimination System \\
\hline NWIS & National Water Information System \\
\hline NWQL & National Water Quality Laboratory \\
\hline PAH & polycyclic aromatic hydrocarbon \\
\hline PCB & polychlorinated biphenyl \\
\hline $\mathrm{pg} / \mathrm{L}$ & picograms per liter \\
\hline SLD & State of New Mexico Department of Health Scientific Laboratory Division \\
\hline SRS & standard reference sample \\
\hline SVOC & semivolatile organic compound \\
\hline USGS & U.S. Geological Survey \\
\hline VOC & volatile organic compound \\
\hline
\end{tabular}





\title{
Summary of Urban Stormwater Quality in Albuquerque, New Mexico, 2003-12
}

\author{
By Erik F. Storms, Gretchen P. Oelsner, Evan A. Locke, Michael R. Stevens, and Orlando C. Romero
}

\section{Abstract}

Urban stormwater in the Albuquerque metropolitan area was sampled by the U.S. Geological Survey in cooperation with the City of Albuquerque, the Albuquerque Metropolitan Arroyo Flood Control Authority, the New Mexico Department of Transportation, and the University of New Mexico. Stormwater was sampled from a network of monitoring stations from 2003 to 2012 by following regulatory requirements for the National Pollutant Discharge Elimination System stormwater permit. During this period, stormwater was sampled in the Albuquerque metropolitan area at outfalls from nine drainage basins with residential, industrial, commercial, agricultural, and undeveloped land uses. Stormwater samples were analyzed for selected physical and chemical characteristics, nutrients, major ions, metals, organic compounds, and bacteria.

General quality of stormwater samples, as measured by dissolved solids, nutrient (with the exception of phosphorus), major ion, and dissolved metal concentrations, was similar to that in samples from the Rio Grande.

Of the nearly 200 organic compounds that were analyzed for this study, less than one-third (58 constituents) were positively identified at or above the analytical detection limit in stormwater. Concentrations for volatile organic compounds, semivolatile organic compounds, polychlorinated biphenyls, and pesticides were generally low in the stormwater samples. Fifteen of the 16 polycyclic aromatic hydrocarbons listed on the U.S. Environmental Protection Agency Priority Chemicals list were detected in at least one stormwater sample from each outfall. Maximum concentrations for some polycyclic aromatic hydrocarbons in stormwater did exceed a waterquality criterion.

Median concentrations for Escherichia coli (E. coli) bacteria in the stormwater samples, including those from the background location (Embudo Arroyo), were above the New Mexico water-quality standard. Concentrations for $E$. coli in stormwater often exceeded the water-quality criterion.

The stormwater quality in Albuquerque was compared with that of six other Western U.S. cities (Phoenix, Arizona; Tucson, Arizona; Las Vegas, Nevada; Denver, Colorado; Salt Lake City, Utah; and Boise, Idaho) for selected constituents. In general, water-quality data for stormwater samples from these six other Western U.S. cities were similar to water-quality data for the stormwater samples from the Albuquerque outfalls. Median concentrations for suspended solids, total phosphorus, and bacteria (E. coli and fecal coliform) in stormwater samples from the Albuquerque outfalls, as a whole, were higher than those in samples from the other Western U.S. cities except for Las Vegas.

\section{Introduction}

From 1992 to 2012, the U.S. Geological Survey (USGS) in cooperation with the City of Albuquerque, the Albuquerque Metropolitan Arroyo Flood Control Authority (AMAFCA), the New Mexico Department of Transportation, and the University of New Mexico collected urban stormwater water-quality data within the City of Albuquerque to meet regulatory requirements for the National Pollutant Discharge Elimination System (NPDES) stormwater permit. This report summarizes the water-quality data that were collected in the last 10 years, between 2003 and 2012. As authorized by the Clean Water Act (86 Stat. 816), the NPDES permit program controls water pollution by regulating point sources that discharge pollutants into waters of the United States. Point sources are discrete conveyances such as pipes or man-made ditches. Industrial, municipal, and other facilities must obtain permits if their discharges go directly to surface waters. Polluted stormwater is commonly transported through Municipal Separate Storm Sewer Systems (MS4s), from which it is often discharged untreated into local water bodies. To prevent harmful pollutants from being washed or dumped into an MS4, operators must obtain an NPDES permit and develop a stormwater management program. Phase I, issued in 1990, requires medium and large cities or certain counties with populations of 100,000 or more to obtain NPDES permit coverage for their stormwater discharges (U.S. Environmental Protection Agency, 1990).

\section{Purpose and Scope}

This report describes the USGS urban stormwater sampling program implemented within the NPDES MS4 
boundaries of the City of Albuquerque and AMAFCA and presents the results of water-quality analyses of stormwater samples collected from 2003 to 2012. The purpose of this report is to (1) describe methods used to collect and analyze urban stormwater samples, (2) discuss the quality-assurance procedures and quality of the data, (3) summarize the quality of urban stormwater discharging to the Rio Grande, (4) compare the quality of urban stormwater between outfalls, and (5) compare the quality of urban stormwater from Albuquerque to that from other large metropolitan areas in the Western United States.

\section{Description of Study Area}

Albuquerque is located in north-central New Mexico (fig. 1). The eastern part of the city lies mainly on the alluvial fans of the Sandia Mountains, the western part lies along the Rio Grande partly on the West Mesa, and the central part lies at lower altitudes on the Rio Grande flood plain. Altitudes in the city range from about 5,000 feet above the North American Vertical Datum of 1988 (NAVD 88) along the Rio Grande to about 7,000 feet above NAVD 88 at the foothills of the Sandia Mountains.

Albuquerque has a semiarid climate; average annual precipitation is about 8 inches (in.) in the lower altitudes near the Rio Grande and increases to about 12 in. at the foothills of the Sandia Mountains (National Oceanic and Atmospheric Administration, 2013). Most of the precipitation occurs as rainstorms from June through September. These rainstorms are typically small convective cells that move rapidly through the area, are often intense, and can result in flash flooding. Very occasionally, large frontal storms that originate from remnant hurricanes in the Gulf of Mexico move into the area (Veenhuis, 2003).

Natural drainage east of the Rio Grande occurs through arroyos (typically dry channels that flow only in response to snowmelt or large rainstorms) that originate at the foothills of the Sandia Mountains and flow westward to the Rio Grande (fig. 1). In areas west of the Rio Grande, arroyos originate along the West Mesa and flow eastward to the Rio Grande. Many of the arroyos are concrete lined to enhance their capacity to convey storm runoff and prevent erosion, whereas other arroyos, particularly in the western part of the city, remain natural.

Albuquerque has a population of about 550,000 (U.S. Census Bureau, 2013). Urban development increased rapidly in the 1980s with the development focused in the northeast quadrant of the city (Veenhuis, 2003). Since the 1990s, however, urban development has been primarily in the West Mesa area.

\section{Drainage Basins and Outfalls}

During 2003-12 in the Albuquerque metropolitan area, USGS and City of Albuquerque personnel collected stormwater samples from nine outfalls (sampling sites; fig. 1) that were chosen to represent different land uses (table 1) and to characterize the quality of stormwater from different regions of the city. The nine outfalls are (1) North Diversion Channel near Alameda, (2) South Diversion Channel above Tijeras Arroyo, (3) Mariposa Diversion of San Antonio Arroyo, (4) the City of Albuquerque Barelas Lift Station no. 32, (5) Tijeras Arroyo near Albuquerque, (6) San Jose Drain at Woodward Road at Albuquerque (7) Embudo Arroyo at Albuquerque, (8) Bear Arroyo at Jefferson Street, and (9) Hahn Arroyo in Albuquerque (fig. 1; table 1). Six of these outfalls discharge stormwater to the Rio Grande; of these, five have USGS streamgages to monitor discharge (no USGS streamgage exists at the City of Albuquerque Barelas Lift Station no. 32 to monitor discharge, and flow there occurs only during storm events).

The North Diversion Channel near Alameda (site UR-9900; hereinafter referred to as "North Diversion Channel") represents the stormwater runoff quality from a 92-square-mile $\left(\mathrm{mi}^{2}\right)$ basin in the northeastern part of Albuquerque (fig. 1). The North Diversion Channel is a north-south trending channel approximately 9 miles (mi) in length and captures flow from 12 smaller channels. Most of the land use in this basin is residential, with some commercial along the major roads and some undeveloped agricultural and open space in the eastern part of the basin. The confluence of the North Diversion Channel with the Rio Grande is located approximately $1 \mathrm{mi}$ northwest of the outfall (fig. 1). Discharge from the North Diversion Channel to the Rio Grande is measured at the North Diversion Channel streamgage (station 08329900) (fig. 1). Stormwater discharge downstream from the streamgage flows into a detention pond before it mixes with the Rio Grande.

The South Diversion Channel above Tijeras Arroyo (site UR-200; hereinafter referred to as "South Diversion Channel") represents stormwater runoff quality in an 11- $\mathrm{mi}^{2}$ basin in the southeastern part of the city (fig. 1). The generally north-south trending channel, approximately $5 \mathrm{mi}$ in length, receives flow from several channels before it combines with the Tijeras Arroyo approximately $1 \mathrm{mi}$ upstream from the Rio Grande. Land use in this basin (fig. 1) includes residential, commercial including the Albuquerque International Airport and the University of New Mexico campus, and undeveloped agricultural and open space. Discharge from the South Diversion Channel to the Rio Grande is measured at the South Diversion Channel streamgage (station 08330775) (fig. 1).

The Mariposa Diversion of San Antonio Arroyo (site UR-300; hereinafter referred to as "San Antonio Arroyo") drains a $31-\mathrm{mi}^{2}$ basin on the west side of the Rio Grande (fig. 1) with land use that is primarily undeveloped agricultural and open space but includes some residential. Discharge from the San Antonio Arroyo to the Rio Grande is measured at the San Antonio Arroyo streamgage (station 083299375) (fig. 1). 


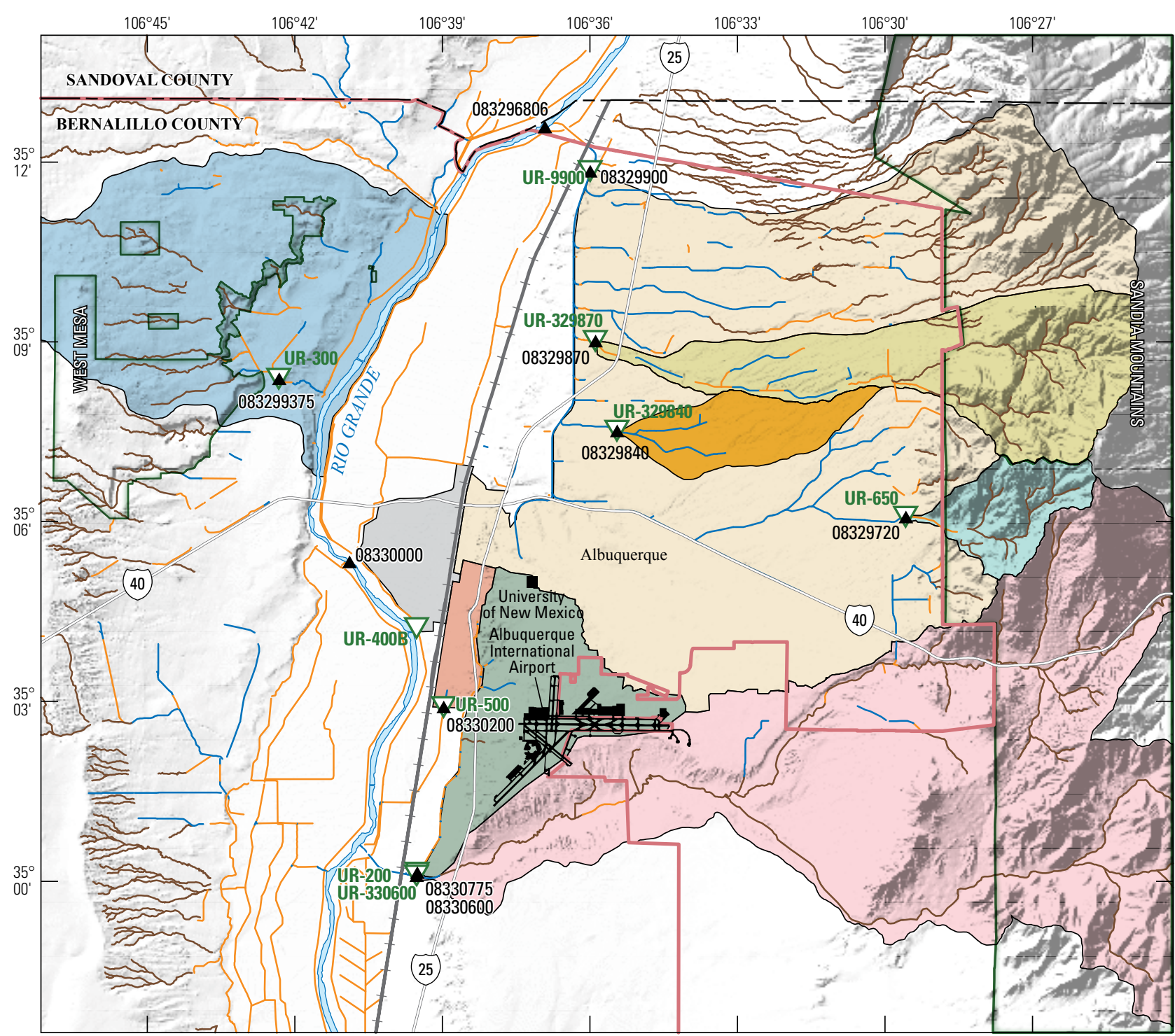

Base map modified from digital data sources, various scales. Coordinate reference system, unknown.
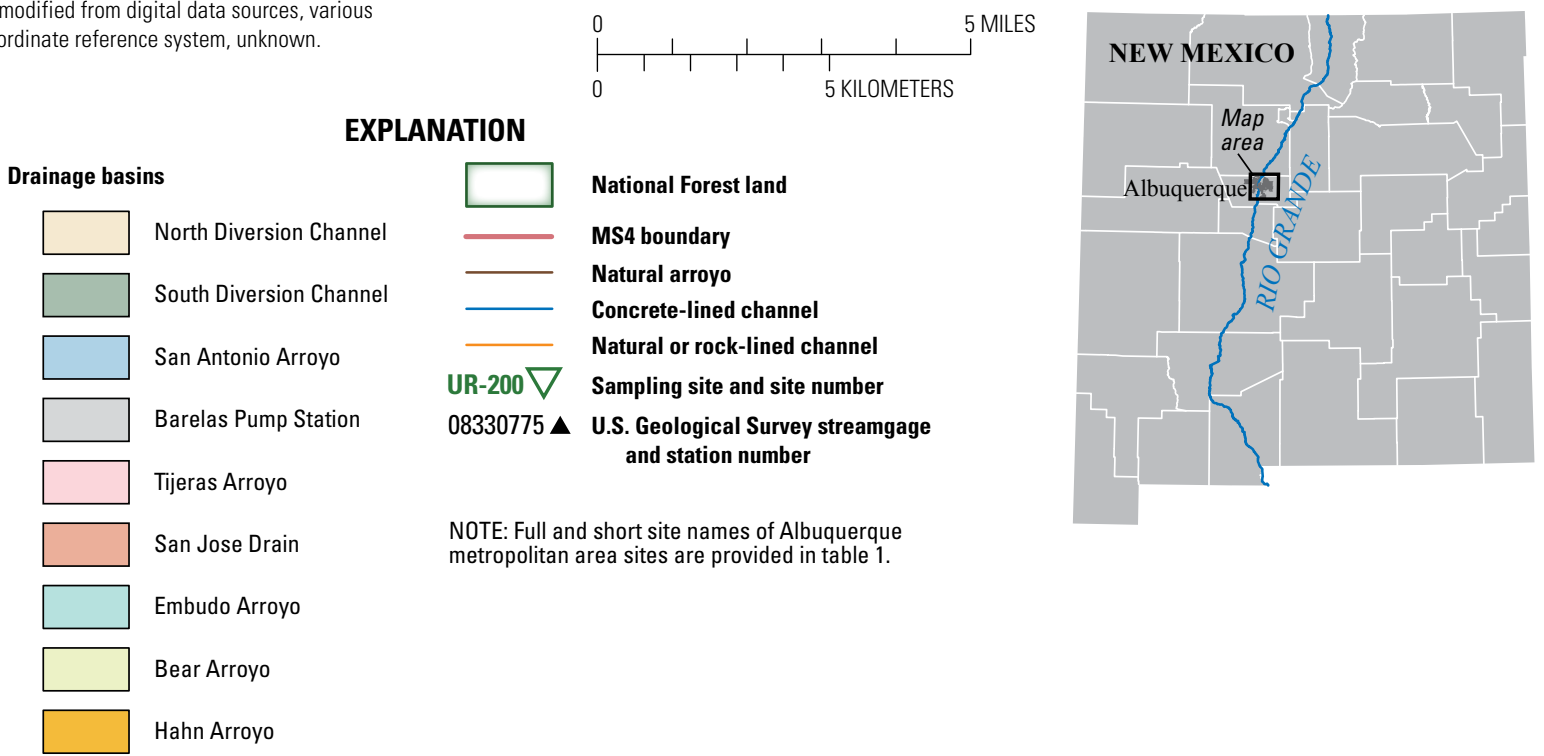

National Forest land

MS4 boundary

Natural arroyo

Concrete-lined channel

Natural or rock-lined channel

UR-200 V Sampling site and site number

08330775 A U.S. Geological Survey streamgage and station number

NOTE: Full and short site names of Albuquerque metropolitan area sites are provided in table 1.

Figure 1. The study area and locations of sampling sites and streamgages, Albuquerque metropolitan area, New Mexico, 2003-12. 
Summary of Urban Stormwater Quality in Albuquerque, New Mexico, 2003-12

Table 1. Site information for stormwater outfalls in the Albuquerque metropolitan area, New Mexico, 2003-12.

[USGS, U.S. Geological Survey; $\mathrm{mi}^{2}$, square miles; \%, percent; -, no station number]

\begin{tabular}{|c|c|c|c|c|c|}
\hline Full site name & $\begin{array}{c}\text { Short site } \\
\text { name }\end{array}$ & $\begin{array}{c}\text { Site } \\
\text { number }\end{array}$ & $\begin{array}{l}\text { Sampling } \\
\text { period }\end{array}$ & $\begin{array}{c}\text { USGS station } \\
\text { number }\end{array}$ & Description $^{1}$ \\
\hline $\begin{array}{l}\text { Embudo Arroyo at } \\
\text { Albuquerque }\end{array}$ & $\begin{array}{l}\text { Embudo } \\
\text { Arroyo }\end{array}$ & UR-650 & 2003-present & 08329720 & $\begin{array}{l}\text { Station located on natural unlined channel. Drains } \\
\text { approximately } 4 \mathrm{mi}^{2} \text {. Land use is } 100 \% \text { open } \\
\text { space. }\end{array}$ \\
\hline $\begin{array}{l}\text { Hahn Arroyo in } \\
\text { Albuquerque }\end{array}$ & Hahn Arroyo & UR-329840 & 2003-present & 08329840 & $\begin{array}{l}\text { Station located on concrete-lined channel. Drains } \\
\text { approximately } 4 \mathrm{mi}^{2} \text {. Land use is } 95 \% \text { residential, } \\
1 \% \text { agricultural, } 1 \% \text { commercial, } 1 \% \text { industrial, } \\
1 \% \text { open space. }\end{array}$ \\
\hline $\begin{array}{l}\text { Bear Arroyo at } \\
\text { Jefferson Street }\end{array}$ & Bear Arroyo & UR-329870 & 2003-present & 08329870 & $\begin{array}{l}\text { Station located on natural unlined channel. Drains } \\
\text { approximately } 15 \mathrm{mi}^{2} \text {. Land use is predominately } \\
\text { commercial and industrial. Actual land use } \\
\text { percentages not determined. }\end{array}$ \\
\hline $\begin{array}{l}\text { North Diversion } \\
\text { Channel near } \\
\text { Alameda }\end{array}$ & $\begin{array}{l}\text { North } \\
\text { Diversion } \\
\text { Channel }\end{array}$ & UR-9900 & 2003-present & 08329900 & $\begin{array}{l}\text { Station located on concrete-lined channel. Drains } \\
\text { approximately } 92 \mathrm{mi}^{2} . \text { Land use is } 41 \% \text { residential, } \\
36 \% \text { agricultural, } 15 \% \text { commercial, } 4 \% \text { industrial, } \\
4 \% \text { open space. }\end{array}$ \\
\hline $\begin{array}{l}\text { Mariposa Diversion of } \\
\text { San Antonio Arroyo }\end{array}$ & $\begin{array}{l}\text { San Antonio } \\
\text { Arroyo }\end{array}$ & UR-300 & 2003-present & 083299375 & $\begin{array}{l}\text { Station located on natural unlined channel. } \\
\text { Drains approximately } 31 \mathrm{mi}^{2} . \text { Land use is } \\
73 \% \text { agricultural, } 14 \% \text { industrial, } 11 \% \text { residential, } \\
1 \% \text { commercial, } 1 \% \text { open space. }\end{array}$ \\
\hline $\begin{array}{l}\text { San Jose Drain at } \\
\text { Woodward Road at } \\
\text { Albuquerque }\end{array}$ & $\begin{array}{c}\text { San Jose } \\
\text { Drain }\end{array}$ & UR-500 & 2003-present & 08330200 & $\begin{array}{l}\text { Station located on concrete-lined channel. Drains } \\
\text { approximately } 2 \mathrm{mi}^{2} . \text { Land use is } 41 \% \text { residential, } \\
30 \% \text { commercial, } 18 \% \text { agricultural, } 9 \% \text { industrial, } \\
2 \% \text { open space. }\end{array}$ \\
\hline $\begin{array}{l}\text { Tijeras Arroyo near } \\
\text { Albuquerque }\end{array}$ & Tijeras Arroyo & UR-330600 & 2011-present & 08330600 & $\begin{array}{l}\text { Station located on natural unlined channel. Drains } \\
\text { approximately } 135 \mathrm{mi}^{2} \text {. Land use is } 90 \% \text { open } \\
\text { space. }\end{array}$ \\
\hline
\end{tabular}

${ }^{1}$ Land use percentages may not equal $100 \%$ because of rounding.

The City of Albuquerque Barelas Lift Station no. 32 (site UR-400B; hereinafter referred to as "Barelas Pump Station") pumps stormwater from a 4-mi basin over a levee and into the Rio Grande. Land use in this basin is primarily residential and commercial; the outfall is located in the Albuquerque downtown area on the east side of the Rio Grande (fig. 1). This outfall flows only during rainstorms. No USGS streamgage exists at this site to monitor discharge. Stormwater samples were historically collected at this site by the City of Albuquerque; however, sampling at this outfall was discontinued in 2011 but was resumed at Tijeras Arroyo near Albuquerque (station 08330600) streamgage (fig. 1).

Tijeras Arroyo near Albuquerque (site UR-330600; hereinafter referred to as “Tijeras Arroyo") drains a 135-mi basin and represents stormwater quality in the southeastern part of the city (fig. 1). The Tijeras Arroyo is a generally east-west trending arroyo approximately $15 \mathrm{mi}$ in length beginning near the foothills of the Sandia Mountains. The arroyo becomes a concrete-lined channel east of the confluence with the South Diversion Channel. The land use in this basin (fig. 1) is primarily undeveloped open space with very little residential and commercial. From 2003 to 2010, stormwater samples collected at Tijeras Arroyo outfall were analyzed for bacteria only; sampling for nutrients, major ions, metals, and organic constituents did not begin until 2011. Discharge from the Tijeras Arroyo to the Rio Grande is measured at the Tijeras Arroyo streamgage (station 08330600) (fig. 1). 
The San Jose Drain at Woodward Road at Albuquerque (site UR-500; hereinafter referred to as "San Jose Drain") drains a $2-\mathrm{mi}^{2}$ basin in the south valley area on the east side of the Rio Grande (fig. 1); flow is transported down a long channel that eventually enters the Rio Grande at the south end of the city. Discharge of the San Jose Drain to the Rio Grande is measured at the San Jose Drain streamgage (station 08330200) (fig. 1). The land use in this basin (fig. 1) is primarily residential and commercial with very little open space.

In addition to characterizing the quality of stormwater in those six basins, stormwater samples were collected from three additional basins to help answer questions from the original analyses (conducted prior to 2003) and to meet permit requirements. Three sampling sites were established in these basins to identify sources of bacterial contamination for the Albuquerque metropolitan area. One of the three sites, Embudo Arroyo at Albuquerque (site UR-650; hereinafter referred to as "Embudo Arroyo"), was established as a background stormwater-quality site and is located near the border between the eastern boundary of Albuquerque and National Forest land (fig. 1). The other two sites, added to represent the quality of stormwater from drainage basins that discharge to the North Diversion Channel, are Bear Arroyo at Jefferson Street (site UR-329870; hereinafter referred to as "Bear Arroyo") and Hahn Arroyo in Albuquerque (site UR-329840; hereinafter referred to as "Hahn Arroyo") (fig. 1).

\section{Comparison of Outfall Discharge With Rio Grande Discharge}

Of the five outfalls that discharge to the Rio Grande and have USGS streamgages to monitor discharge, the North Diversion Channel contributes the greatest discharge by volume, with the greatest annual number of flow days (table 2) and the greatest annual volume of discharge (table 3). For the 10-year period from 2003 to 2012, the North Diversion Channel contributed, on average, 72.7 percent of the total combined annual discharge of the five outfalls with recorded discharges into the Rio Grande (table 3; no USGS streamgage exists at the Barelas Pump Station to monitor discharge, and flow occurs there only during storm events) and contributed a 10 -year mean of approximately 1.1 percent of the total annual flow to the Rio Grande as measured at the Rio Grande at Albuquerque streamgage (station 08330000; fig. 1; table 4).

Total annual discharge contributions from all five streamgages to the Rio Grande ranged from 0.7 to 2.8 percent of the total annual flow of the Rio Grande as measured at the Rio Grande at Albuquerque streamgage with a 10-year mean of 1.4 percent. During large rainstorms, when dams upstream minimize the flow in the Rio Grande, discharge from the North Diversion Channel contributes greater than 50 percent of the daily mean flow of the Rio Grande. Discharge data are available in the USGS National Water Information System (NWIS) database (http://waterdata.usgs.gov/nwis/sw).
Table 2. Annual number of flow days at sampled outfalls with U.S. Geological Survey streamgages, Albuquerque metropolitan area, New Mexico, 2003-12.

[A flow day is defined as a mean daily value of 5 cubic feet per second or greater. Full site names are provided in table 1]

\begin{tabular}{lccccc}
\hline $\begin{array}{c}\text { Water } \\
\text { year }\end{array}$ & $\begin{array}{c}\text { North } \\
\text { Diversion } \\
\text { Channel } \\
\text { (station } \\
\text { 08329900) }\end{array}$ & $\begin{array}{c}\text { South } \\
\text { Diversion } \\
\text { Channel } \\
\text { (station } \\
\text { 08330775) }\end{array}$ & $\begin{array}{c}\text { Tijeras } \\
\text { Arroyo } \\
\text { (station } \\
\text { 08330600) }\end{array}$ & $\begin{array}{c}\text { San } \\
\text { Antonio } \\
\text { Arroyo } \\
\text { (station } \\
\text { 083299375) }\end{array}$ & $\begin{array}{c}\text { San } \\
\text { Jose } \\
\text { Drain } \\
\text { (station }\end{array}$ \\
\hline 2003 & 81 & 3 & 6 & 1 & 5 \\
2004 & 61 & 12 & 13 & 2 & 16 \\
2005 & 108 & 19 & 15 & 0 & 5 \\
2006 & 65 & 19 & 26 & 8 & 8 \\
2007 & 64 & 15 & 8 & 3 & 4 \\
2008 & 64 & 9 & 11 & 1 & 1 \\
2009 & 113 & 5 & 4 & 3 & 2 \\
2010 & 70 & 13 & 14 & 2 & 2 \\
2011 & 52 & 5 & 4 & 0 & 2 \\
2012 & 68 & 8 & 5 & 0 & 1 \\
\hline 10 -year & 74.6 & 10.8 & 10.6 & 2.0 & 4.6 \\
mean & & & & & \\
$(2003-12)$ & & & & & \\
\hline
\end{tabular}

\section{Stormwater Sampling Procedures}

Although perennial flow occurred in the Rio Grande during the period of study (2003-12), no perennial flow occurred in drainage channels and natural stream channels in the study area. Flow occurred in these channels primarily from rainstorms and during the spring snowmelt (AprilMay). Nonstormwater discharges occasionally occurred from overwatering of lawns and parks located along the channels or from flushing of municipal wells or hydrants. In general, water-quality sampling can only be conducted during or after a precipitation event. Most rainfall occurred during the summer monsoon season (June-September), which is considered the "wet" season; conversely, October through May is considered the "dry" season. Depending on precipitation events, sample collection was conducted two times per year at each outfall, with a minimum of one sample to be collected during the wet season and one sample collected during the dry season. Fecalcoliform and Escherichia coli (E. coli) sample collection was conducted at least two times per year at each outfall. During years of below normal precipitation, the collection of two stormwater samples per year at each outfall was not always possible. 
Table 3. Annual volume of stormwater discharge at sampled outfalls with U.S. Geological Survey streamgages, Albuquerque metropolitan area, New Mexico, 2003-12.

[Full site names are provided in table 1. Ten-year mean is based on annual runoff for the years 2003-12]

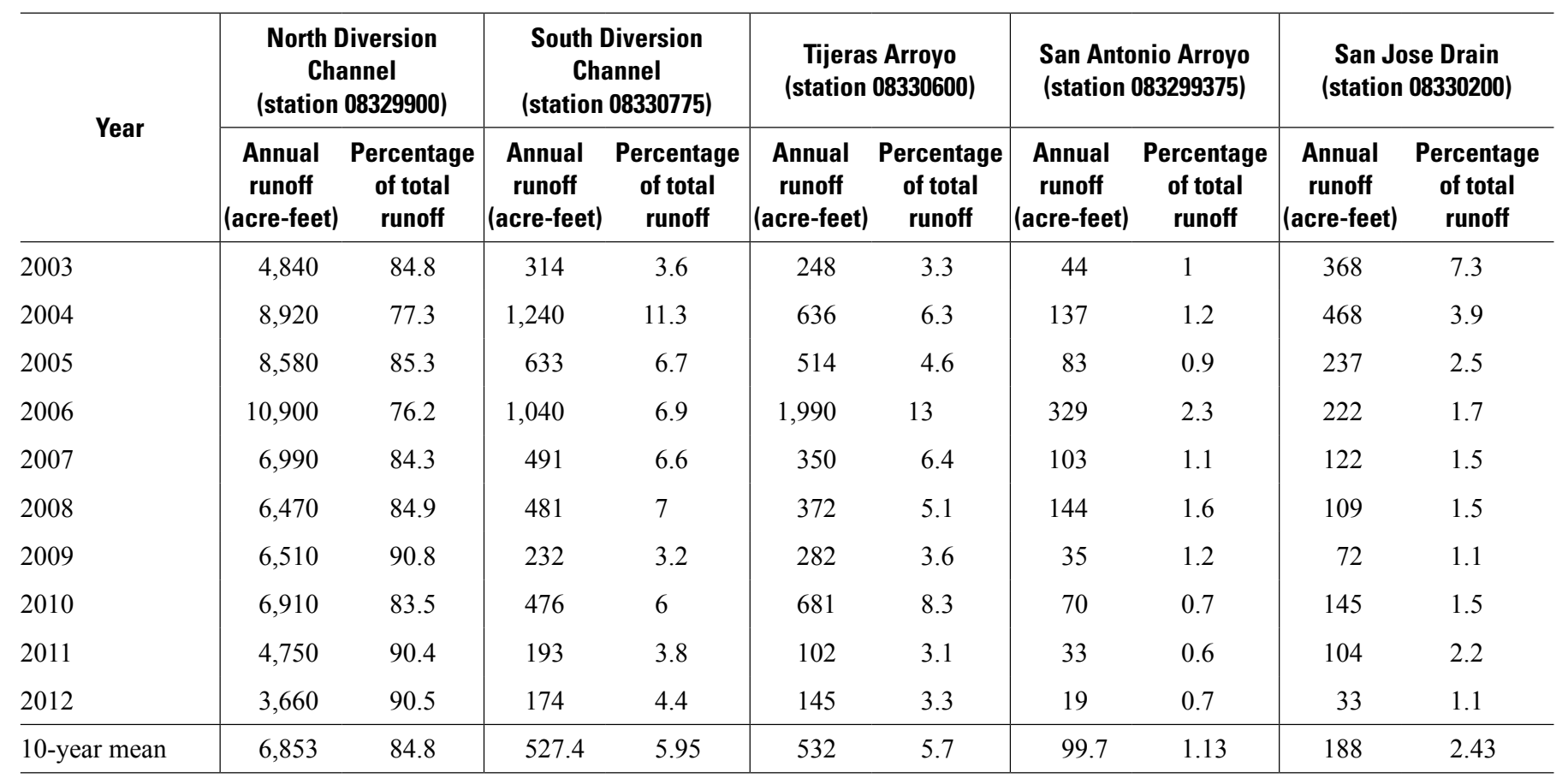

Table 4. Annual stormwater discharge contributions of the North Diversion Channel to the total annual flow of the Rio Grande as measured at the Rio Grande at Albuquerque streamgage, Albuquerque metropolitan area, New Mexico, 2003-12.

[Full site names of Albuquerque metropolitan area sites are provided in table 1. Ten-year mean is based on annual discharges for the years 2003-12. Outfall discharge totals are the sum of the discharges for the North Diversion Channel (station 08329900), South Diversion Channel (station 08330775), Tijeras Arroyo (station 08330600), San Antonio Arroyo (station 08329975), and San Jose Arroyo (station 08330200) outfalls]

\begin{tabular}{|c|c|c|c|c|c|}
\hline \multirow[b]{2}{*}{ Year } & \multicolumn{3}{|c|}{$\begin{array}{l}\text { Annual discharge } \\
\text { (acre-feet) }\end{array}$} & \multicolumn{2}{|c|}{$\begin{array}{l}\text { Percentage of discharge contribution } \\
\text { to the Rio Grande at Albuquerque }\end{array}$} \\
\hline & $\begin{array}{c}\text { Rio Grande at } \\
\text { Albuquerque } \\
\text { (station 08330000) }\end{array}$ & $\begin{array}{l}\text { North Diversion } \\
\text { Channel } \\
\text { (station 08329900) }\end{array}$ & $\begin{array}{c}\text { Total of all } \\
\text { Albuquerque } \\
\text { outfalls }\end{array}$ & $\begin{array}{l}\text { North Diversion } \\
\text { Channel } \\
\text { (station 08329900) }\end{array}$ & $\begin{array}{c}\text { Total of all } \\
\text { Albuquerque } \\
\text { outfalls }\end{array}$ \\
\hline 2003 & 318,300 & 4,840 & 5,814 & 1.5 & 1.8 \\
\hline 2005 & $1,159,000$ & 8,580 & 10,047 & 0.7 & 0.9 \\
\hline 2006 & 512,300 & 10,900 & 14,481 & 2.1 & 2.8 \\
\hline 2007 & 674,700 & 6,990 & 8,056 & 1.0 & 1.2 \\
\hline 2008 & $1,102,000$ & 6,470 & 7,576 & 0.6 & 0.7 \\
\hline 2012 & 390,000 & 3,660 & 4,031 & 0.9 & 1.0 \\
\hline 10 -year mean & 670,250 & 6,853 & 8,200 & 1.1 & 1.4 \\
\hline
\end{tabular}


Throughout each year, but more commonly during the summer monsoon season, rainstorms sometimes occurred on consecutive days. To meet the NPDES permit requirement of sampling representative storm events, stormwater samples were collected from discharges resulting from storm events that were greater than $0.1 \mathrm{in}$. in magnitude and that occurred at least 72 hours from a previously measurable (greater than $0.1 \mathrm{in}$. of rainfall) storm event. Although a 72-hour period is desired, the North Diversion Channel was rarely completely dry for 72 hours prior to sample collection during the summer monsoon season because precipitation events occurred in some part of the drainage basin almost daily. In addition, nonstormwater discharges occasionally occurred from watering of lawns and parks and from flushing of municipal wells or hydrants along channels that feed into the North Diversion Channel.

Since the inception of the USGS urban stormwater sampling program in the Albuquerque study area in 1992, every stormwater-quality sample collected from basin outfalls in the network has consisted of an initial grab sample and a sequence of discrete stormwater samples. During this study, the initial grab sample was collected during the first 20 minutes of storm runoff to represent the highest concentrations for constituents of concern that may have accumulated in the channel. The sequence of discrete stormwater samples was conducted at even intervals (ranging from 10 to 20 minutes), beginning after the first 30 minutes and throughout the first 3 hours of runoff. The discrete stormwater samples were then composited by using a flow-weighted method in which the volume of each discrete sample was dependent upon the discharge at the time of collection (U.S. Geological Survey, variously dated). A greater discharge at the time of collection, therefore, resulted in a greater volume of sample added to the mixture. The final flow-weighted composite sample represented the quality of the stormwater during the first 3 hours of runoff.

\section{Water-Quality Constituents}

Twelve of the constituents analyzed in the composite stormwater samples are priority constituents identified by the U.S. Environmental Protection Agency (EPA) (U.S. Environmental Protection Agency, 1990) as major contaminants in stormwater (table 5). The priority constituents are dissolved solids, suspended solids, total Kjeldahl nitrogen, total nitrogen, dissolved phosphorus, total phosphorus, biochemical oxygen demand (BOD), chemical oxygen demand (COD), total extractable cadmium, total extractable copper, total extractable lead, and total extractable zinc (table 5). Stormwater samples were also analyzed for the dissolved fraction of selected trace elements to determine trace element contribution to the Rio Grande. Fecal-coliform bacteria

Table 5. Water-quality constituents analyzed in urban stormwater samples from outfalls, Albuquerque metropolitan area, New Mexico, 2003-12.

\begin{tabular}{|c|c|c|}
\hline Nutrients & Organic constituents & Bacteria \\
\hline Kjeldahl nitrogen, total $^{1}$ & Oil and grease & Escherichia coli \\
\hline Nitrate, dissolved as nitrogen & Organochlorine pesticides and arochlors (27 compounds) & \\
\hline Nitrite plus nitrate, dissolved as nitrogen, total & Phenols & Fecal coliform \\
\hline Phosphorus, dissolved ${ }^{1}$ & Semivolatile organic compounds (56 compounds) & \\
\hline Phosphorus, total ${ }^{1}$ & Volatile organic compounds (61 compounds) & \\
\hline Total nitrogen ${ }^{1}$ & & \\
\hline
\end{tabular}

Select physical and chemical constituents

\begin{tabular}{l} 
Biochemical oxygen demand $^{1}$ \\
Chemical oxygen demand $^{1}$ \\
Dissolved solids ${ }^{1}$ \\
pH \\
Specific conductance \\
Suspended solids $^{1}$ \\
\hline \multicolumn{1}{c}{ Major ions }
\end{tabular}

Alkalinity

Calcium, dissolved

Chloride, dissolved

Magnesium, dissolved

Potassium, dissolved

Sodium, dissolved

Sulfate, dissolved
Metals

(all total concentrations are extractable)
Aluminum, total
Antimony, total
Arsenic, total
Beryllium, total
Cadmium, total ${ }^{1}$
Chromium total
Copper, total $^{1}$
Cyanide, total
Lead, total ${ }^{1}$
Mercury, total
Nickel, total
Selenium, total
Silver, total
Thallium, total
Zinc, total $^{1}$

Aluminum, dissolved
Arsenic, dissolved
Beryllium, dissolved
Cadmium, dissolved
Chromium, dissolved
Copper, dissolved
Lead, dissolved
Mercury, dissolved
Nickel, dissolved
Selenium, dissolved
Silver, dissolved
Zinc, dissolved

${ }^{1}$ Indicates the 12 U.S. Environmental Protection Agency priority constituents. 
populations were determined for each grab sample. Other constituents analyzed in the stormwater grab samples included selected pesticides, Aroclor and congener polychlorinated biphenyls (PCBs), volatile organic compounds (VOCs), selected semivolatile organic compounds (SVOCs), phenols, oil and grease, and selected organic compounds.

\section{Sample Collection}

Most stormwater sampling sites were located at outfalls with streamgages which have permanent shelters that house a flow-monitoring recorder, a water-level sensor (pressure transducer), and an automated pump sampler. Streamflow data were collected and reviewed in accordance with USGS protocols as described in Buchanan and Somers (1982). Precipitation data were collected in accordance with USGS protocols as described in the Office of Surface Water Technical Memorandum 2006.01 (U.S. Geological Survey, 2006). All hydrologic data were published in the USGS NWIS database (http://waterdata.usgs.gov/nwis/sw), and some of the data were published in the USGS Annual Water Data Reports (http://wdr.water.usgs.gov/).

Stormwater samples were collected by using an automated sampler at all stations except for San Antonio Arroyo outfall, where stormwater samples were collected manually. Manual sampling during storm events was often difficult because of the high flow velocities and the danger of being in the channel during higher flows.

Manual stormwater samples were collected by submerging and filling 1-liter baked amber glass bottles directly from the stream. The amber glass bottles were precleaned and were each used only once. Nitrile gloves were worn by personnel when handling the sample bottles (U.S. Geological Survey, variously dated).

For automated sampling during the study, automatic peristaltic pump samplers were programmed to collect stormwater samples according to the NPDES permit requirements. An automatic sampler was designed to initiate a sampling routine when a sensor (actuator) located near the channel bottom was triggered by a flow event. The bottle fill times logged by the automatic sampler were then compared to stream discharge measurement intervals to perform the flowweighting computations.

The automatic samplers used either 1-gallon glass reusable containers or 1-liter polycarbonate reusable containers that were each lined with a disposable 1-liter plastic sampling bag. All reusable sample containers were cleaned before being placed into the automated sampler prior to a storm event. The 1-liter plastic bags were discarded after each use. The sample tubing associated with the peristaltic pump was replaced annually and was flushed with 1 gallon of deionized water after each sampling event. Prior to installation of the replacement tubing, the tubing was precleaned in the laboratory.

Stormwater samples were retrieved as soon as possible after a flow event and were immediately chilled for transport back to the USGS New Mexico Water Science Center in Albuquerque, where they were then processed according to USGS protocols (U.S. Geological Survey, variously dated). The sequence for sample collection and processing was based on logistics for maintaining sample integrity (U.S. Geological Survey, variously dated). All stormwater samples were promptly delivered to the appropriate analytical laboratory to meet the holding time for the constituent with the shortest holding time.

\section{Quality Assurance and Quality Control}

Quality-assurance procedures for the field and the laboratory were conducted throughout the duration of this study in accordance with USGS protocols (U.S. Geological Survey, variously dated). Field quality-assurance practices involved the calibration of field meters and the cleaning of sampling equipment prior to sampling events. Stormwater samples were collected, preserved, and shipped in accordance with applicable USGS protocols described in U.S. Geological Survey (variously dated). During this study, three different water-quality laboratories were used to analyze the stormwater samples: (1) the USGS National Water Quality Laboratory (NWQL) in Denver, Colorado; (2) the Albuquerque Bernalillo County Water Utility Authority (ABCWUA) Laboratory in Albuquerque; and (3) the State of New Mexico Department of Health Scientific Laboratory Division (abbreviated by the department and referred to hereinafter as "SLD") in Albuquerque. The SLD analyzed nutrients and selected organic compounds, whereas the ABCWUA Laboratory, located at the ABCWUA Southside Water Reclamation Plant, analyzed for bacteria, metals, phenols, oil and grease, major ions, BOD, COD, and dissolved solids. The USGS NWQL was primarily used for replicate analysis of stormwater samples submitted to the ABCWUA Laboratory and the SLD.

To assess the quality of the laboratory data, replicate stormwater samples were used during field sampling. Replicate stormwater samples, sometimes referred to as "splits," were collected at all sites and were obtained by dividing the water collected for each analysis into two bottles. The purpose of a replicate sample is to evaluate the precision between samples when the samples are sent to the same laboratory or to evaluate the precision of the laboratory when the replicates are sent to separate laboratories.

Equipment blank samples collected at each site were obtained by passing blank, deionized water that is treated as a sample through all components of the sample collection apparatus. The chemical analysis of a blank sample determines the adequacy of cleaning procedures between sampled sites or quantifies carryover of any chemical contamination between sites. Results from equipment blank testing can indicate whether the equipment cleaning procedures were effective or if the environmental samples were contaminated or otherwise affected. 


\section{Sample Processing}

Stormwater samples were transported in chilled coolers to the USGS New Mexico Water Science Center for processing before being transported to the laboratory. Stormwater samples were processed promptly to meet constituent holding times. Processing equipment included sample splitters (churn splitters) and filtration units. Processing for each sample was dependent on whether the sample was a grab or a composite. For each set of stormwater samples, the grab sample was the first sample processed. The sample was decanted into a clean Teflon-coated churn splitter and agitated to ensure that wholewater stormwater subsamples contained equal amounts of suspended and dissolved constituents. Stormwater subsamples for bacteria determinations were collected before the sample was placed in the churn splitter because the churn splitter cannot be sterilized in an autoclave. The stormwater samples were bottled and preserved with the appropriate chemical treatment and chilled (U.S. Geological Survey, variously dated).

After the grab sample was processed, the flow-weighted composite sample was processed in the same manner as the grab sample. The churn splitter was agitated, and bottles were filled for analysis of the constituents that did not require filtering. After the bottles for the unfiltered constituents were filled, no more agitation was required, and the remaining stormwater subsamples were filtered and bottled. The stormwater samples were then preserved with the appropriate chemical treatment and chilled (U.S. Geological Survey, variously dated).

Split stormwater samples were prepared by partitioning a volume of processed stormwater samples from the churn splitter into equal subsamples. In some cases, stormwater subsamples for a particular analyte were delivered to the same laboratory (either the ABCWUA Laboratory or the SLD) to determine analytical precision. In a few cases, one set of stormwater subsamples for an entire suite of analytes was sent to the USGS NWQL to determine the variability in analytical results between the USGS NWQL and the local laboratories.

After the stormwater samples were processed, they were placed in a chilled cooler and transported to either the ABCWUA Laboratory or the SLD. The determination of which laboratory received which stormwater samples depended on the required analysis.

\section{Laboratory Methods}

Standard operating procedures for the USGS NWQL are detailed in Maloney (2005). During 2011 and 2012, PCB congener analyses were performed by TestAmerica Laboratories, Inc., for the USGS. The list of water-quality constituents analyzed for in stormwater samples and the EPA analytical test methods used by the ABCWUA, the SLD, and the USGS are presented in table 6. Occasionally during the study, different analytical methods were used by a laboratory that had lower than usual detection limits. As a result, it is possible to have a value for a constituent quantified at a level below the common detection limit.

Stormwater samples sent to the ABCWUA Laboratory were analyzed for bacteria, cyanide, metals, phenols, oil and grease, major ions, $\mathrm{BOD}, \mathrm{COD}$, and dissolved solids. The ABCWUA Laboratory standard operating procedures are presented in appendix 1. Stormwater samples sent to the SLD were analyzed for VOCs, nutrients, SVOCs, and Aroclor PCBs. The SLD standard operating procedures are presented in appendix 2.

\section{Quality Assurance of Urban Stormwater Data}

\section{Data Compilation}

Data collected as part of this study were compiled into a Microsoft Access database to facilitate data analysis. Data analyzed at the SLD from 2003 to 2010 were provided in an electronic spreadsheet to the USGS. Since 2011, the USGS has received analytical results from the SLD for VOCs, SVOCs, and polycyclic aromatic hydrocarbons (PAHs) in electronic spreadsheet format. Since 2011, nutrient data from SLD has been received in paper format and manually entered into the database. Data analyzed at the ABCWUA Laboratory between 2003 and 2008 were provided in an electronic spreadsheet. Time of sample collection was missing for a large number of these records from the ABCWUA Laboratory and was entered manually from the field notes. Since 2008, the USGS has received electronic spreadsheets from the ABCWUA Laboratory 1-2 times per year with analysis results. Data analyzed at the USGS NWQL were retrieved from the NWIS database (http://waterdata.usgs.gov/nwis).

Because the data came from different sources, each with its own naming conventions, each data source had to be reconciled to a common format. Parameter names, fractions, and units were all standardized among the data sources. By using a standardized parameter list based on the USGS parameter codes (PCODEs), which represent a unique combination of parameter, fraction, and unit, each constituent from the SLD and the ABCWUA Laboratory was assigned a PCODE to make the data readily comparable. Qualifier codes from each laboratory were standardized, and censored results with zero values were replaced by the minimum detection limit. Some constituents were analyzed for in both EPA analytical test methods, $8260 \mathrm{~B}$ and $8270 \mathrm{D}$, and therefore had two results per sample. If both values were censored, the minimum value was used in the analysis. If one of the values was not censored, the maximum value was used in the analysis. 
Table 6. List of water-quality constituents, U.S. Environmental Protection Agency analytical test methods, and analytical laboratories used for constituent analysis of urban stormwater samples from outfalls, Albuquerque metropolitan area, New Mexico, 2003-12.

$[\mu \mathrm{g} / \mathrm{L}$, micrograms per liter; ABCWUA, Albuquerque Bernalillo County Water Utility Authority; SLD, State of New Mexico Department of Health Scientific Laboratory Division; mg/L, milligrams per liter; N, nitrogen; P, phosphorus; MPN/100 mL, most probable number per 100 milliliters; USGS, U.S. Geological Survey National Water Quality Laboratory; SM, Standard Method]

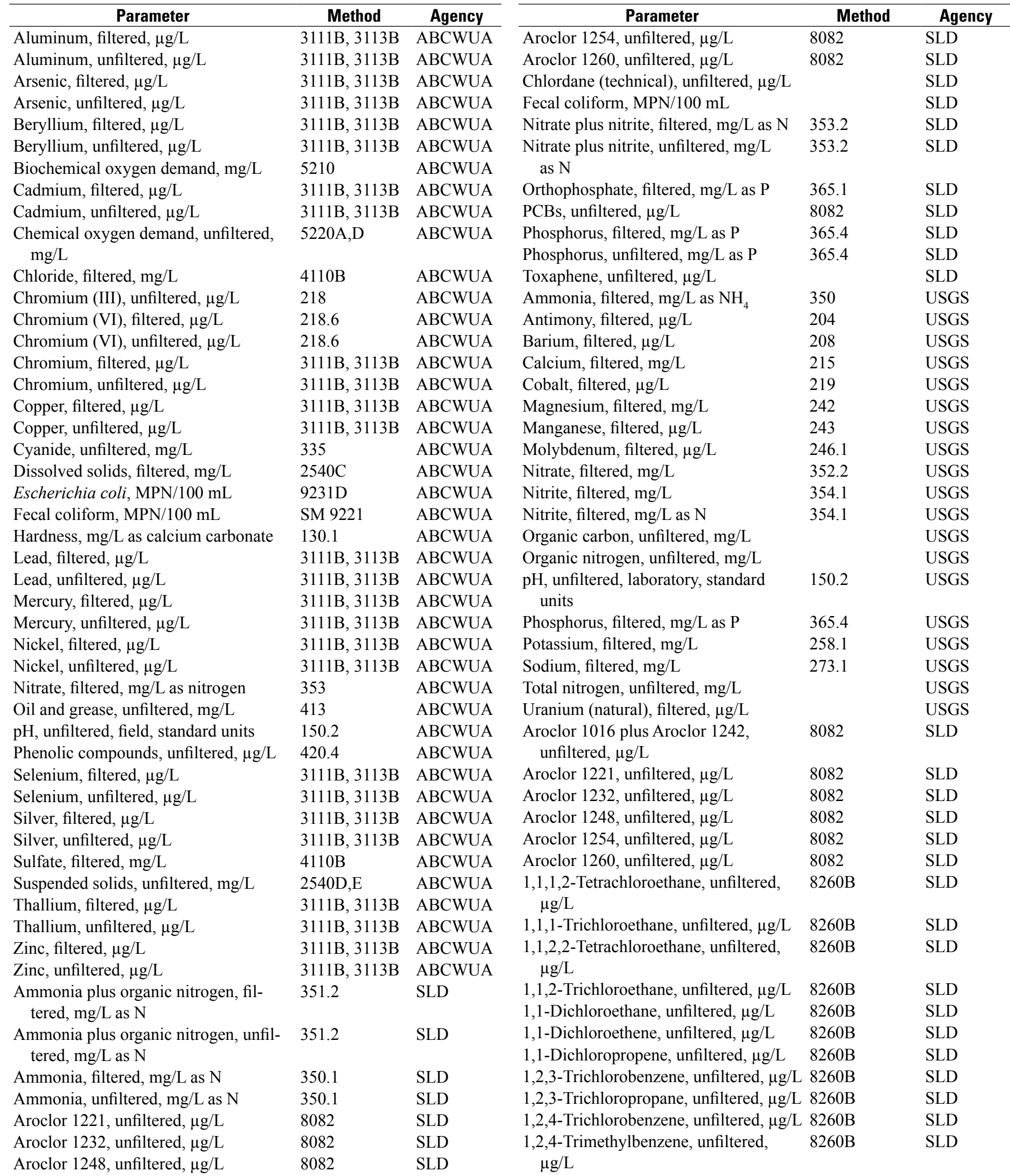


Table 6. List of water-quality constituents, U.S. Environmental Protection Agency analytical test methods, and analytical laboratories used for constituent analysis of urban stormwater samples from outfalls, Albuquerque metropolitan area, New Mexico, 2003-12.Continued

$[\mu \mathrm{g} / \mathrm{L}$, micrograms per liter; ABCWUA, Albuquerque Bernalillo County Water Utility Authority; SLD, State of New Mexico Department of Health Scientific Laboratory Division; mg/L, milligrams per liter; N, nitrogen; P, phosphorus; MPN/100 mL, most probable number per 100 milliliters; USGS, U.S. Geological Survey National Water Quality Laboratory; SM, Standard Method]

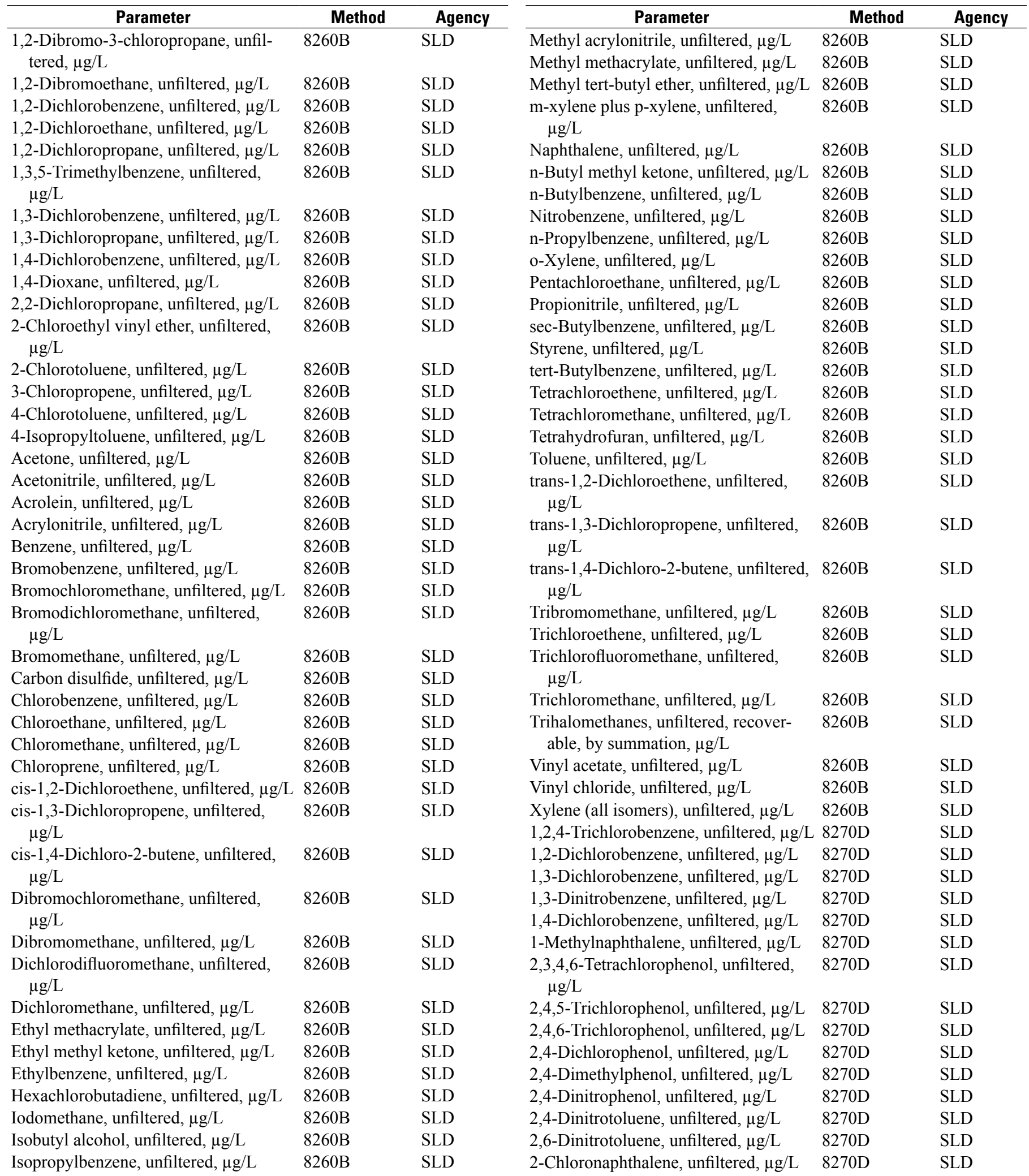


Table 6. List of water-quality constituents, U.S. Environmental Protection Agency analytical test methods, and analytical laboratories used for constituent analysis of urban stormwater samples from outfalls, Albuquerque metropolitan area, New Mexico, 2003-12.Continued

$[\mu \mathrm{g} / \mathrm{L}$, micrograms per liter; ABCWUA, Albuquerque Bernalillo County Water Utility Authority; SLD, State of New Mexico Department of Health Scientific Laboratory Division; mg/L, milligrams per liter; N, nitrogen; P, phosphorus; MPN/100 mL, most probable number per 100 milliliters; USGS, U.S. Geological Survey National Water Quality Laboratory; SM, Standard Method]

\begin{tabular}{|c|c|c|c|c|c|}
\hline Parameter & Method & Agency & $\begin{array}{r}\text { Parameter } \\
\end{array}$ & Method & Agency \\
\hline 2-Chlorophenol, unfiltered, $\mu \mathrm{g} / \mathrm{L}$ & $8270 \mathrm{D}$ & SLD & Chrysene, unfiltered, $\mu \mathrm{g} / \mathrm{L}$ & $8270 \mathrm{D}$ & SLD \\
\hline \multirow{2}{*}{$\begin{array}{l}\text { 2-Methyl-4,6-dinitrophenol, unfiltered, } \\
\mu \mathrm{g} / \mathrm{L}\end{array}$} & \multirow[t]{2}{*}{$8270 \mathrm{D}$} & \multirow[t]{2}{*}{ SLD } & cis-Chlordane, unfiltered, $\mu \mathrm{g} / \mathrm{L}$ & $8270 \mathrm{D}$ & SLD \\
\hline & & & Cyanazine, unfiltered, $\mu \mathrm{g} / \mathrm{L}$ & $8270 \mathrm{D}$ & SLD \\
\hline 2-Methylnaphthalene, unfiltered, $\mu \mathrm{g} / \mathrm{L}$ & $8270 \mathrm{D}$ & SLD & delta-HCH, unfiltered, $\mu \mathrm{g} / \mathrm{L}$ & 8270D & SLD \\
\hline 2-Nitroaniline, unfiltered, $\mu \mathrm{g} / \mathrm{L}$ & $8270 \mathrm{D}$ & SLD & Dibenzo[a,h]anthracene, unfiltered, & $8270 \mathrm{D}$ & SLD \\
\hline 2-Nitrophenol, unfiltered, $\mu \mathrm{g} / \mathrm{L}$ & $8270 \mathrm{D}$ & SLD & $\mu \mathrm{g} / \mathrm{L}$ & & \\
\hline 3,3'-Dichlorobenzidine, unfiltered, $\mu \mathrm{g} / \mathrm{L}$ & 8270D & SLD & Dibenzofuran, unfiltered, $\mu \mathrm{g} / \mathrm{L}$ & $8270 \mathrm{D}$ & SLD \\
\hline 3-Nitroaniline, unfiltered, $\mu \mathrm{g} / \mathrm{L}$ & $8270 \mathrm{D}$ & SLD & Dieldrin, unfiltered, $\mu \mathrm{g} / \mathrm{L}$ & $8270 \mathrm{D}$ & SLD \\
\hline \multirow{2}{*}{$\begin{array}{l}\text { 4-Bromophenyl phenyl ether, unfiltered, } \\
\mu \mathrm{g} / \mathrm{L}\end{array}$} & \multirow{2}{*}{$8270 \mathrm{D}$} & \multirow[t]{2}{*}{ SLD } & Diethyl phthalate, unfiltered, $\mu \mathrm{g} / \mathrm{L}$ & $8270 \mathrm{D}$ & SLD \\
\hline & & & Dimethyl phthalate, unfiltered, $\mu \mathrm{g} / \mathrm{L}$ & $8270 \mathrm{D}$ & SLD \\
\hline \multirow{2}{*}{$\begin{array}{l}\text { 4-Chloro-3-methylphenol, unfiltered, } \\
\mu \mathrm{g} / \mathrm{L}\end{array}$} & \multirow[t]{2}{*}{$8270 \mathrm{D}$} & \multirow[t]{2}{*}{ SLD } & Di-n-butyl phthalate, unfiltered, $\mu \mathrm{g} / \mathrm{L}$ & $8270 \mathrm{D}$ & SLD \\
\hline & & & Di-n-octyl phthalate, unfiltered, $\mu \mathrm{g} / \mathrm{L}$ & 8270D & SLD \\
\hline 4-Chloroaniline, unfiltered, $\mu \mathrm{g} / \mathrm{L}$ & 8270D & SLD & Endosulfan sulfate, unfiltered, $\mu \mathrm{g} / \mathrm{L}$ & $8270 \mathrm{D}$ & SLD \\
\hline \multirow{2}{*}{$\begin{array}{l}\text { 4-Chlorophenyl phenyl ether, unfiltered, } \\
\mu \mathrm{g} / \mathrm{L}\end{array}$} & \multirow{2}{*}{$8270 \mathrm{D}$} & \multirow[t]{2}{*}{ SLD } & Endrin aldehyde, unfiltered, $\mu \mathrm{g} / \mathrm{L}$ & $8270 \mathrm{D}$ & SLD \\
\hline & & & Endrin ketone, unfiltered, $\mu \mathrm{g} / \mathrm{L}$ & $8270 \mathrm{D}$ & SLD \\
\hline 4-Nitroaniline, unfiltered, $\mu \mathrm{g} / \mathrm{L}$ & 8270D & SLD & Endrin, unfiltered, $\mu \mathrm{g} / \mathrm{L}$ & $8270 \mathrm{D}$ & SLD \\
\hline 4-Nitrophenol, unfiltered, $\mu \mathrm{g} / \mathrm{L}$ & 8270D & SLD & Fluoranthene, unfiltered, $\mu \mathrm{g} / \mathrm{L}$ & $8270 \mathrm{D}$ & SLD \\
\hline 9H-Fluorene, unfiltered, $\mu \mathrm{g} / \mathrm{L}$ & $8270 \mathrm{D}$ & SLD & Heptachlor epoxide, unfiltered, $\mu \mathrm{g} / \mathrm{L}$ & 8270D & SLD \\
\hline Acenaphthene, unfiltered, $\mu \mathrm{g} / \mathrm{L}$ & 8270D & SLD & Heptachlor, unfiltered, $\mu \mathrm{g} / \mathrm{L}$ & 8270D & SLD \\
\hline Acenaphthylene, unfiltered, $\mu \mathrm{g} / \mathrm{L}$ & $8270 \mathrm{D}$ & SLD & Hexachlorobenzene, unfiltered, $\mu \mathrm{g} / \mathrm{L}$ & 8270D & SLD \\
\hline Alachlor, filtered, $\mu \mathrm{g} / \mathrm{L}$ & 8270D & SLD & Hexachlorobutadiene, unfiltered, $\mu \mathrm{g} / \mathrm{L}$ & $8270 \mathrm{D}$ & SLD \\
\hline \multirow{3}{*}{$\begin{array}{l}\text { Aldrin, unfiltered, } \mu \mathrm{g} / \mathrm{L} \\
\text { alpha-Endosulfan, unfiltered, } \mu \mathrm{g} / \mathrm{L}\end{array}$} & $8270 \mathrm{D}$ & SLD & \multirow{2}{*}{$\begin{array}{l}\text { Hexachlorocyclopentadiene, unfiltered, } \\
\mu \mathrm{g} / \mathrm{L}\end{array}$} & \multirow{2}{*}{$8270 \mathrm{D}$} & \multirow[t]{2}{*}{ SLD } \\
\hline & $8270 \mathrm{D}$ & SLD & & & \\
\hline & $8270 \mathrm{D}$ & SLD & Hexachloroethane, unfiltered, $\mu \mathrm{g} / \mathrm{L}$ & 8270D & SLD \\
\hline Aniline, unfiltered, $\mu \mathrm{g} / \mathrm{L}$ & $8270 \mathrm{D}$ & SLD & \multirow{2}{*}{$\begin{array}{l}\text { Indeno[1,2,3-cd]pyrene, unfiltered, } \\
\mu \mathrm{g} / \mathrm{L}\end{array}$} & \multirow[t]{2}{*}{$8270 \mathrm{D}$} & \multirow{2}{*}{ SLD } \\
\hline Anthracene, unfiltered, $\mu \mathrm{g} / \mathrm{L}$ & $8270 \mathrm{D}$ & SLD & & & \\
\hline Atrazine, unfiltered, $\mu \mathrm{g} / \mathrm{L}$ & $8270 \mathrm{D}$ & SLD & Isophorone, unfiltered, $\mu \mathrm{g} / \mathrm{L}$ & $8270 \mathrm{D}$ & SLD \\
\hline Azobenzene, unfiltered, $\mu \mathrm{g} / \mathrm{L}$ & $8270 \mathrm{D}$ & SLD & Lindane, unfiltered, $\mu \mathrm{g} / \mathrm{L}$ & $8270 \mathrm{D}$ & SLD \\
\hline Benzidine, unfiltered, $\mu \mathrm{g} / \mathrm{L}$ & 8270D & SLD & Metolachlor, unfiltered, $\mu \mathrm{g} / \mathrm{L}$ & $8270 \mathrm{D}$ & SLD \\
\hline Benzo[a]anthracene, unfiltered, $\mu \mathrm{g} / \mathrm{L}$ & $8270 \mathrm{D}$ & SLD & Metribuzin, unfiltered, $\mu \mathrm{g} / \mathrm{L}$ & 8270D & SLD \\
\hline Benzo[a]pyrene, unfiltered, $\mu \mathrm{g} / \mathrm{L}$ & 8270D & SLD & Naphthalene, unfiltered, $\mu \mathrm{g} / \mathrm{L}$ & 8270D & SLD \\
\hline Benzo[b]fluoranthene, unfiltered, $\mu \mathrm{g} / \mathrm{L}$ & $8270 \mathrm{D}$ & SLD & Nitrobenzene, unfiltered, $\mu \mathrm{g} / \mathrm{L}$ & 8270D & SLD \\
\hline \multirow{2}{*}{$\begin{array}{l}\text { Benzo[ghi]perylene, unfiltered, } \mu \mathrm{g} / \mathrm{L} \\
\text { Benzo[k]fluoranthene, unfiltered, } \mu \mathrm{g} / \mathrm{L}\end{array}$} & $8270 \mathrm{D}$ & SLD & \multirow{2}{*}{$\begin{array}{l}\text { N-Nitrosodimethylamine, unfiltered, } \\
\mu \mathrm{g} / \mathrm{L}\end{array}$} & $8270 \mathrm{D}$ & SLD \\
\hline & 8270D & SLD & & & \\
\hline Benzoic acid, unfiltered, $\mu \mathrm{g} / \mathrm{L}$ & $8270 \mathrm{D}$ & SLD & N-Nitrosodi-n-propylamine, unfiltered, & $8270 \mathrm{D}$ & SLD \\
\hline Benzyl alcohol, unfiltered, $\mu \mathrm{g} / \mathrm{L}$ & 8270D & SLD & $\mu \mathrm{g} / \mathrm{L}$ & & \\
\hline $\begin{array}{l}\text { Benzyl n-butyl phthalate, unfiltered, } \\
\mu \mathrm{g} / \mathrm{L}\end{array}$ & $8270 \mathrm{D}$ & SLD & $\begin{array}{l}\text { N-Nitrosodiphenylamine, unfiltered, } \\
\mu \mathrm{g} / \mathrm{L}\end{array}$ & $8270 \mathrm{D}$ & SLD \\
\hline beta-Endosulfan, unfiltered, $\mu \mathrm{g} / \mathrm{L}$ & 8270D & SLD & $\mathrm{o}-C r e s o l$, unfiltered, $\mu \mathrm{g} / \mathrm{L}$ & 8270D & SLD \\
\hline beta-HCH, unfiltered, $\mu \mathrm{g} / \mathrm{L}$ & $8270 \mathrm{D}$ & SLD & $\mathrm{p}, \mathrm{p}$-DDD, unfiltered, $\mu \mathrm{g} / \mathrm{L}$ & 8270D & SLD \\
\hline Bis(2-chloroethoxy)methane, unfiltered, & $8270 \mathrm{D}$ & SLD & $\mathrm{p}, \mathrm{p}^{\prime}-\mathrm{DDE}$, unfiltered, $\mu \mathrm{g} / \mathrm{L}$ & $8270 \mathrm{D}$ & SLD \\
\hline$\mu \mathrm{g} / \mathrm{L}$ & & & $\mathrm{p}, \mathrm{p}^{\prime}-\mathrm{DDT}$, unfiltered, $\mu \mathrm{g} / \mathrm{L}$ & $8270 \mathrm{D}$ & SLD \\
\hline Bis(2-chloroethyl) ether, unfiltered, & $8270 \mathrm{D}$ & SLD & $\mathrm{p}, \mathrm{p}$-Methoxychlor, unfiltered, $\mu \mathrm{g} / \mathrm{L}$ & $8270 \mathrm{D}$ & SLD \\
\hline$\mu \mathrm{g} / \mathrm{L}$ & & & Pentachlorophenol, unfiltered, $\mu \mathrm{g} / \mathrm{L}$ & $8270 \mathrm{D}$ & SLD \\
\hline Bis(2-chloroisopropyl) ether, unfiltered, & 8270D & SLD & Phenanthrene, unfiltered, $\mu \mathrm{g} / \mathrm{L}$ & 8270D & SLD \\
\hline$\mu \mathrm{g} / \mathrm{L}$ & & & Phenol, unfiltered, $\mu \mathrm{g} / \mathrm{L}$ & $8270 \mathrm{D}$ & SLD \\
\hline Bis(2-ethylhexyl) adipate, unfiltered, & $8270 \mathrm{D}$ & SLD & Prometryn, unfiltered, $\mu \mathrm{g} / \mathrm{L}$ & $8270 \mathrm{D}$ & SLD \\
\hline$\mu \mathrm{g} / \mathrm{L}$ & & & Pyrene, unfiltered, $\mu \mathrm{g} / \mathrm{L}$ & $8270 \mathrm{D}$ & SLD \\
\hline Bis(2-ethylhexyl) phthalate, unfiltered, & $8270 \mathrm{D}$ & SLD & Pyridine, unfiltered, $\mu \mathrm{g} / \mathrm{L}$ & 8270D & SLD \\
\hline$\mu \mathrm{g} / \mathrm{L}$ & & & trans-Chlordane, unfiltered, $\mu \mathrm{g} / \mathrm{L}$ & 8270D & SLD \\
\hline Carbazole, unfiltered, $\mu \mathrm{g} / \mathrm{L}$ & $8270 \mathrm{D}$ & SLD & & & \\
\hline
\end{tabular}




\section{Quality Assurance of the Data}

Quality of urban stormwater is highly variable under natural conditions, which complicates assessing the quality of the data. It is important not only to identify data that should not be used for interpretation or assessment because of transcription errors, data coding errors, or measurement system problems but also not to exclude true extreme values that indicate more variability in the population than was anticipated. Qualityassured data used in this report are provided in appendix 3.

There were two phases of the data review. The first phase was screening designed to assess the quality of the data as it pertains to laboratory analyses including reviewing laboratory remarks, field blanks, replicate stormwater samples, standard reference samples, and comparison of sample fraction results. Specific data quality standards were determined for this report as described in this section and were based on the "Quality-Assurance Plan for Water-Quality Activities in the New Mexico Water Science Center" (S. Anderholm, USGS New Mexico Water Science Center, written commun., 2010). Data that failed to meet these standards were flagged as rejected in the database and were not used in this report.

The second phase was screening that used statistical analyses to identify outliers in the data that may be the result of unusual conditions. Data that were identified as statistical outliers were flagged in the database but were included in the "Data Summary" section.

Remark codes or flags from the laboratories regarding the condition of stormwater samples, holding time exceedances, or issues with the analyses were reviewed to ensure adequacy of data for use in the study. The SLD and the USGS NWQL regularly reported laboratory remark codes. The ABCWUA Laboratory, however, provided electronic comments on the data analysis only for stormwater samples collected during 2008 , and these comments were reviewed for data assessment purposes. Stormwater samples were rejected if holding times were exceeded or if there was an indication of unsatisfactory analysis or laboratory contamination.

Field blanks were collected from 2000 to 2010 and checked to ensure that the results were acceptable. Field blanks were not collected after 2010 because the results from 2000 to 2010 indicated that there was no contamination introduced during sample collection and processing.

Generally, one replicate stormwater sample was collected per site per year, and the analyses for all constituent groups were replicated; however, the limited volume of stormwater restricted the number of replicate stormwater samples that were collected and used in quality assurance. The replicate stormwater sample, therefore, was sometimes collected for one constituent group or analytical schedule at a time. When it was possible to collect replicate stormwater samples, the analyses were compared to ensure that the values were within 20 percent of each other. If the results were not within 20 percent of each other, the results were rejected.

A full suite of major ion data was not collected regularly. Ion balance between cations and anions, therefore, was not completed as part of the quality-assurance procedure.
The concentration of a constituent in an unfiltered (total) sample should be greater than the concentration in a filtered (dissolved) sample. Total and dissolved fractions were compared by constituent to identify instances in which dissolved values were greater than total values. If a dissolved concentration was more than 20 percent greater than a total concentration for a given constituent, the data were noted as such (app. 3) and not rejected in the database. Occasionally, bottles of unfiltered and filtered stormwater samples can be mislabeled or confused at the laboratory. If more than one constituent from the same sample had dissolved values more than 20 percent greater than the total values, all of the constituents included in the laboratory analysis method were flagged as rejected in the database and were not used in this statistical summary because some bottle confusion was suspected.

Both the SLD and the ABCWUA Laboratory participate in the USGS Branch of Quality Systems Standard Reference Sample (SRS) Program for nutrients (the SLD), major ions, and trace elements (the ABCWUA Laboratory). There are usually 2 sets of SRSs per year-1 set in spring and 1 set in fall. According to Woodworth and Connor (2003), results with an absolute $\mathrm{z}$-value greater than 2.00 are considered unsatisfactory, where the $z$-value is analogous to the standard deviation from a most probable value that is based on results from all participating SRS Program laboratories, which includes more than 100 laboratories from across the United States. Because of the low concentrations in the SRSs compared to the concentrations in the stormwater discharge, the USGS did not reject data unless the absolute z-value was greater than 3.00. The historical SRS results were reviewed, the laboratories were contacted about unsatisfactory results, and nutrient and trace element data were flagged in the database when the laboratories did not perform adequately. If the absolute $\mathrm{z}$-value was greater than 3.00 for a given constituent during one SRS set, data were rejected for the time period of poor laboratory performance. In cases where the low nutrient standard values were moderately unsatisfactory for a given constituent but the corresponding high nutrient standard values were acceptable, the samples were not rejected on the basis of the average concentrations in the stormwater discharge.

Two statistical tests were used to identify statistical outliers in the data: (1) interquartile range (IQR) and (2) median absolute deviation (MAD) (Davies and Gather, 1993). The IQR was used for constituents with many censored (nondetected) values. The MAD test is a robust method of detecting outliers in data with a nonnormal distribution. Details about the MAD test are described in Davies and Gather (1993). Any value identified as an outlier with the MAD test or as greater than three times the IQR was flagged as a statistical outlier in the database.

There were some data that appeared higher or lower than usual but were not rejected or determined to be statistical outliers. These data were assigned the qualitative flag of "visually suspicious" in the database but were used in this data summary. 


\section{Data Analysis Methods}

\section{Boxplots}

Boxplots graphically display the median, IQR, and quartile skewness for selected data. The median is the 50th-percentile value, which indicates that 50 percent of the data are less than or equal to that reported value. The center line of the boxplot represents the median. The IQR represents the middle 50 percent of the data, or the difference between the upper quartile (75th percentile) and lower quartile (25th percentile) values. The quartile skewness can be seen by comparing the portion of the box above and below the median line. For a linear scale, if the upper portion is larger than the lower portion, the data are skewed to the higher concentrations. The lines extending from the top and bottom of the boxplot are referred to as "whiskers." The "hinges" are the horizontal lines that define the points above which lie one-fourth of the values and below which lie the other three-fourths of the values. The upper whisker extends from the hinge to the highest value that is within 1.5 times the IQR of the hinge. The lower whisker extends from the hinge to the lowest value within 1.5 times the IQR of the hinge. The censored-data values are represented by open dots, and actual detected values are represented by solid dots.

Because analytical techniques vary among laboratories and through time, multiple detection limits might exist for a given constituent. Additionally, detection limits of constituents are frequently elevated when high constituent concentrations are present in the sample, requiring dilution for accurate quantitation and instrument protection. If dilution is required, the detection limit of all compounds is elevated by the dilution factor, regardless of their presence or absence, which may result in some cases of nondetected concentrations being higher than the detected concentrations shown on the boxplots.

\section{Comparison to New Mexico Water-Quality Standards}

The observed constituent concentrations were compared to the New Mexico water-quality standards (NM WQSs) as described in State of New Mexico Standards for Interstate and Intrastate Surface Waters (20.6.4 New Mexico Administrative Code [20.6.4 NMAC]). These standards have several usespecific criteria and vary depending on the designated use. The designated uses selected in this study were those for domestic water supply, livestock watering, aquatic life toxicity, and human health-organism only (HH-OO). The NM WQSs define "domestic water supply" as surface water of the State that could be used for drinking or culinary purposes after disinfection. The NM WQSs define "livestock watering" as surface water of the State used as a supply of water for consumption by livestock. The NM WQSs define "aquatic life toxicity" by criteria based on concentrations that can impair the community of plants and animals in or the ecological integrity of surface waters. Freshwater aquatic life criteria for some metals (including aluminum, cadmium, chromium [III], copper, lead, manganese, nickel, silver, and zinc) are expressed as a function of total hardness. The aquatic life criteria values used in this study for metals (table 7) correspond to a total hardness of 80 milligrams per liter $(\mathrm{mg} / \mathrm{L})$ on the basis of the overall median and mean hardness values at the outfalls. The NM WQSs define "HH-OO" by criteria based on the health of humans who ingest fish or other aquatic organisms from waters that contain constituents of concern.

\section{Determination of Data Outliers}

Streamwater chemistry can vary throughout the year as a result of seasonal changes and storm runoff (Tate and others, 1999); some maximum concentrations in data can be outliers and are not always representative of typical water-quality conditions at the outfall. To determine which maximum values were data outliers, a statistical analysis of the data was performed. A robust statistical test based on the median and the standard deviation values (Davies and Gather, 1993) was used to detect outliers in this nonnormal dataset. For each constituent from a representative sampling site, the outlier threshold (upper MAD outlier limit) was determined as any value that exceeded the median value plus 5.2 times the MAD value. If an individual concentration or result was greater than the limit determined by this calculation, then it was considered a data outlier for purposes of discussion in this report. Data determined to be outliers represent unusually high concentrations but are not considered to be incorrect values and may or may not exceed regulatory criteria.

\section{Comparison to Published Stormwater Data}

The quality of urban stormwater in Albuquerque was compared with stormwater quality in other arid and semiarid regions in the Western United States. A literature search was conducted, and published studies from six other major metropolitan areas in the Western United States were selected for comparison, including (1) Phoenix, Arizona (Lopes and others, 1995); (2) Tucson, Arizona (Pitt and others, 2008); (3) Boise, Idaho (Kjelstrom, 1995); (4) Denver (Stevens and Slaughter, 2012); (5) Salt Lake City, Utah (Stantec Consulting, 2009); and (6) Las Vegas, Nevada (Montgomery Watson Harza, 2004). Water-quality data from these locations were generally limited to physical and chemical characteristics, nutrients, and selected metals. Studies were conducted in the Phoenix and Tucson study areas during 1991-93, the Las Vegas study area during 1992-2004, the Denver study area during 2006-10, the Salt Lake City study area during 2008, and the Boise study area during 1993-94. For each city, unless noted otherwise, data from all stations were combined to determine a single median concentration for each constituent. 
Table 7. Concentration screening criteria for constituents in urban stormwater runoff samples from outfalls in the Albuquerque metropolitan area, New Mexico, 2003-12.

[NM DWS, New Mexico domestic water-supply standard; mg/L, milligrams per liter; RGB, Rio Grande Basin; $\mathrm{CaCO}_{3}$, calcium carbonate; -, no value; $\mu \mathrm{g} / \mathrm{L}$, micrograms per liter; $\mu \mathrm{S} / \mathrm{cm}$ at $25^{\circ} \mathrm{C}$, microsiemens per centimeter at 25 degrees Celsius; N, nitrogen; $\mathrm{P}$, phosphorus. Freshwater aquatic life criteria for metals are expressed as a function of total hardness $\left(\mathrm{mg} / \mathrm{L}\right.$ as $\left.\mathrm{CaCO}_{3}\right)$ in the water body; values displayed correspond to a total hardness of $80 \mathrm{mg} / \mathrm{L}$ as $\mathrm{CaCO}$. Freshwater acute aquatic life criteria for total (unfiltered) ammonia are expressed as a function of $\mathrm{pH}$ and the presence or absence of salmonids; values displayed correspond to a $\mathrm{pH}$ of 7.8 and absence of salmonids based on the overall median and average $\mathrm{pH}$ and absence of salmonids at the outfalls. Freshwater chronic aquatic life criteria for total ammonia are expressed as a function of $\mathrm{pH}$ and water temperature in the water body; values displayed correspond to a pH of 7.8 and temperature greater than 15 degrees Celsius based on the overall median and average $\mathrm{pH}$ and temperature values at the outfalls; for aquatic life concentrations, the first listed value is the acute concentration limit, and the second listed value is the chronic concentration limit]

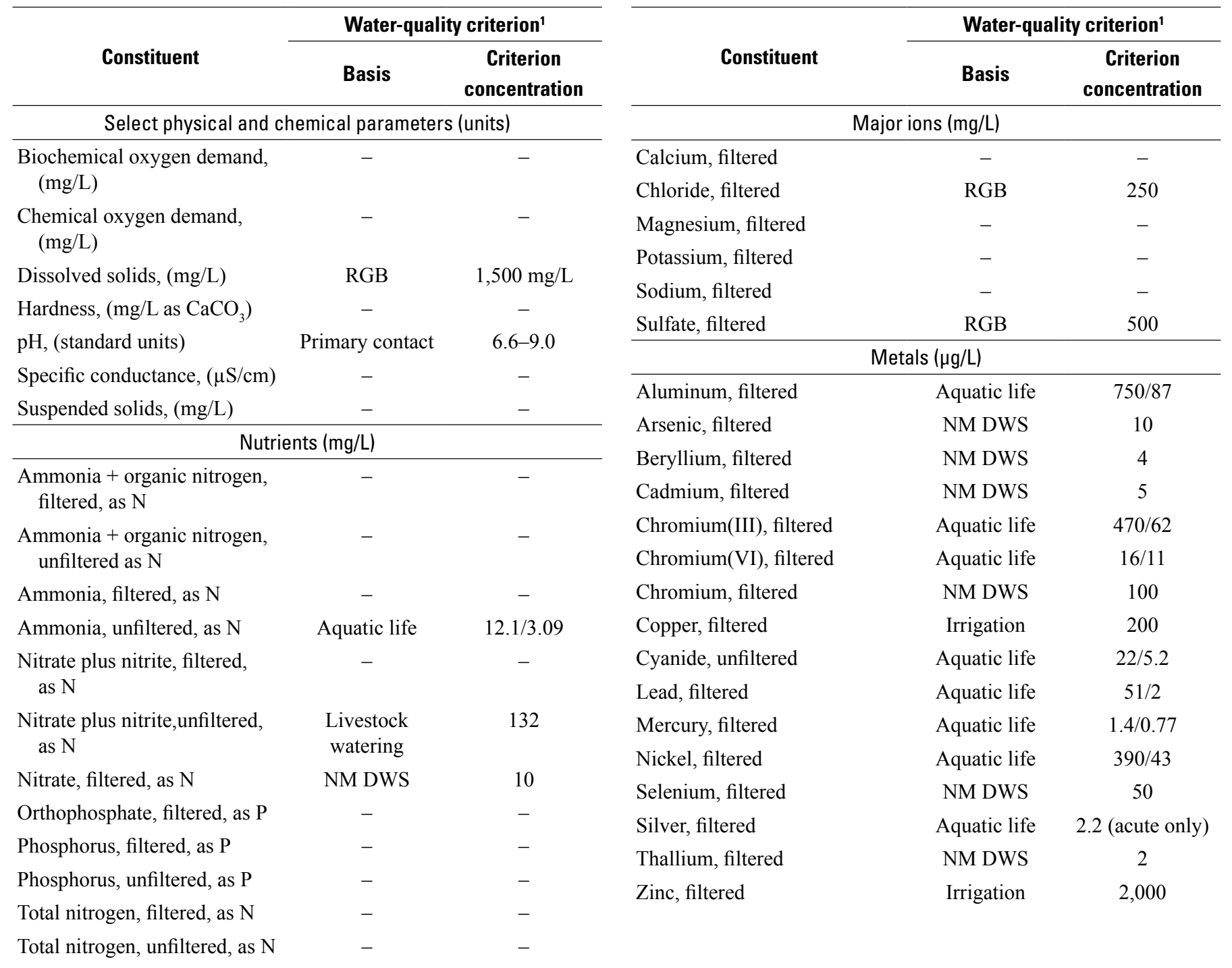


Table 7. Concentration screening criteria for constituents in urban stormwater runoff samples from outfalls in the Albuquerque metropolitan area, New Mexico, 2003-12.-Continued

[NM DWS, New Mexico domestic water-supply standard; mg/L, milligrams per liter; RGB, Rio Grande Basin; $\mathrm{CaCO}_{3}$, calcium carbonate; -, no value; $\mu \mathrm{g} / \mathrm{L}$, micrograms per liter; $\mu \mathrm{S} / \mathrm{cm}$ at $25^{\circ} \mathrm{C}$, microsiemens per centimeter at 25 degrees Celsius; N, nitrogen; P, phosphorus. Freshwater aquatic life criteria for metals are expressed as a function of total hardness $\left(\mathrm{mg} / \mathrm{L} \mathrm{as} \mathrm{CaCO}_{3}\right)$ in the water body; values displayed correspond to a total hardness of $80 \mathrm{mg} / \mathrm{L}$ as $\mathrm{CaCO}$. Freshwater acute aquatic life criteria for total (unfiltered) ammonia are expressed as a function of $\mathrm{pH}$ and the presence or absence of salmonids; values displayed correspond to a pH of 7.8 and absence of salmonids based on the overall median and average $\mathrm{pH}$ and absence of salmonids at the outfalls. Freshwater chronic aquatic life criteria for total ammonia are expressed as a function of $\mathrm{pH}$ and water temperature in the water body; values displayed correspond to a pH of 7.8 and temperature greater than 15 degrees Celsius based on the overall median and average $\mathrm{pH}$ and temperature values at the outfalls; for aquatic life concentrations, the first listed value is the acute concentration limit, and the second listed value is the chronic concentration limit]

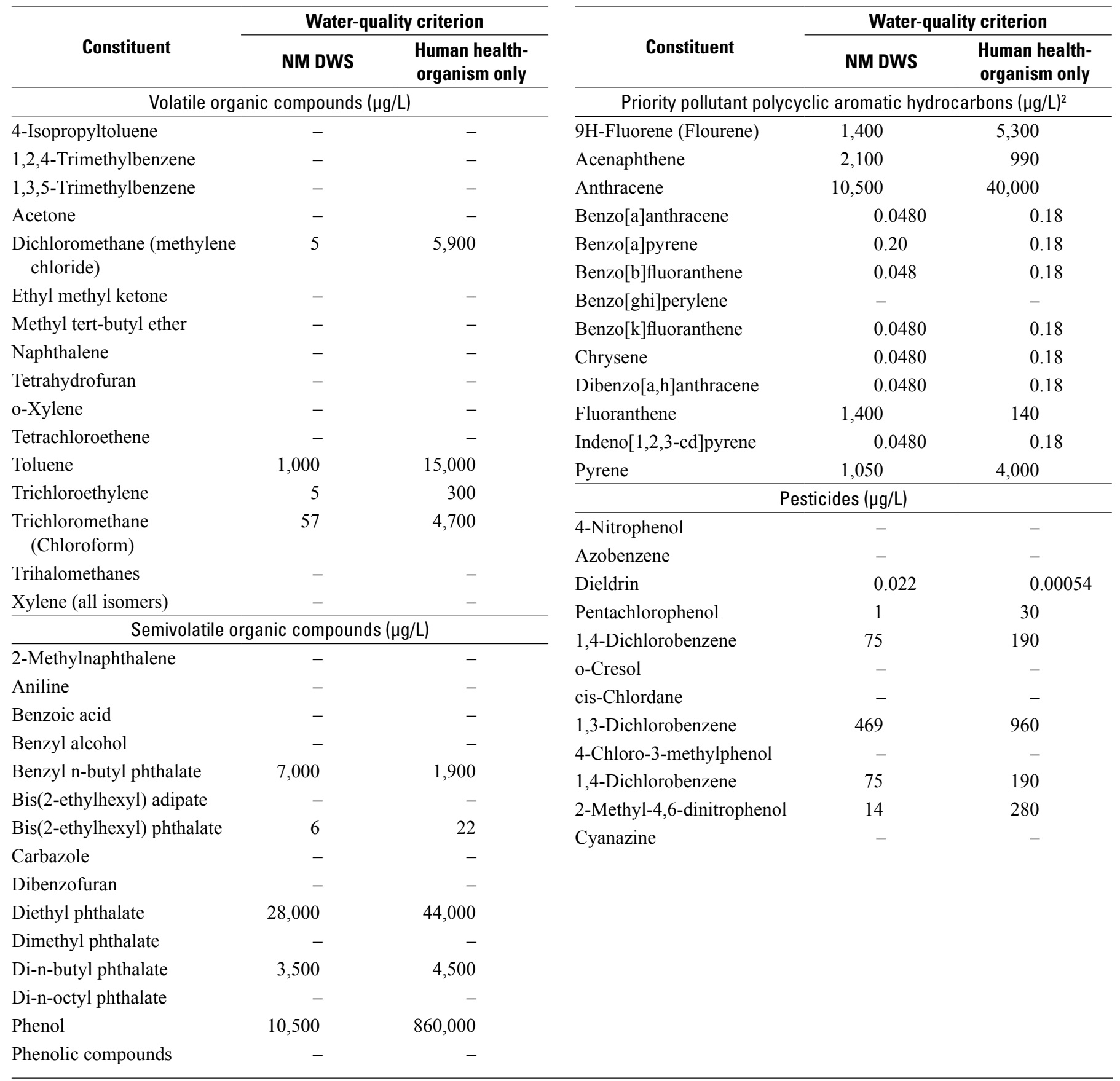

${ }^{1}$ New Mexico water-quality standards (NM WQSs) as described in State of New Mexico Standards for Interstate and Intrastate Surface Waters (20.6.4 New Mexico Administrative Code).

${ }^{2}$ U.S. Environmental Protection Agency (2014a). 
Water-quality data for Phoenix were from a USGS study conducted by Lopes and others (1995), which was based on stormwater samples collected from five drainage basins at stations located on tributaries of the Salt River within the Phoenix metropolitan area. Water-quality data for Tucson were from an evaluation of NPDES stormwater data conducted by Pitt and others (2008) and included stormwater samples collected from four stations located on tributaries of the Santa Cruz River. Water-quality data for Las Vegas were associated with a Las Vegas Valley NPDES municipal stormwater discharge permit (Montgomery Watson Harza, 2004) and were based on stormwater samples collected from 7 stations located on tributaries of Las Vegas Wash and 2 stations located on Las Vegas Wash. Water-quality data for Denver were from a USGS study conducted by Stevens and Slaughter (2012), which was based on stormwater samples collected from 2 stations, 1 on a tributary of the South Platte River and 1 on a tributary to Sand Creek. Median constituent concentrations were determined for these two stations separately and were not combined to represent Denver as a whole. Water-quality data for Salt Lake City were from a report prepared for the Utah Department of Transportation and Salt Lake County by Stantec Consulting (2009) and were based on stormwater samples from two stations that represented mixed and residential land use; median constituent concentrations were determined for each station. Water-quality data for Boise are from a USGS study conducted by Kjelstrom (1995), in which stormwater was sampled at five storm sewer outfalls in the Garden City area of Boise.

\section{Data Summary}

An assessment of water-quality data collected from the outfalls in the Albuquerque metropolitan area was made by summarizing the chemical composition of stormwater discharging to the Rio Grande and comparing the composition of stormwater among outfalls. Basic statistics, including minimum, median, mean, and maximum, were calculated for each constituent at each outfall (tables 8-18). Most of the water-quality data for the Tijeras Arroyo outfall (except for bacteria data) were not used as part of this data summary because sampling at this site for a full suite of analytes did not begin until 2011 and there were only 1 or 2 stormwater samples for most constituents. The number of analyses for bacteria (fecal coliform and E. coli) for the Tijeras Arroyo outfall, however, was sufficient for characterization and is included in this summary. At all sites, the water-quality data collected included selected physical and chemical characteristics, major ions, nutrients, metals, organic compounds, and bacteria. Median and maximum observed constituent concentrations were screened against criterion concentration values, and any exceedances were noted.

For all sites, boxplots were used to compare the chemical composition among outfalls for selected constituents. When plotted on the same scale, boxplots can be compared visually, and differences and similarities among outfalls can be identified. In some cases where a maximum value was much higher than the values of other data points, the maximum value was removed from the boxplot so that the distribution of the remaining data could be shown more clearly.

\section{Selected Physical and Chemical Characteristics}

Physical characteristics and chemical concentrations of water quality, such as $\mathrm{pH}$, specific conductance, dissolved solids, suspended solids, BOD and COD, are important in assessing water quality. Changing physical characteristics and chemical concentrations in a stream can be an indicator of increasing pollution. Most of these selected physical characteristics and chemical concentrations do not have any established mandatory NM WQSs for domestic water supply or other designated use (20.6.4 NMAC). General water quality as measured by dissolved solids concentrations in stormwater samples from the Albuquerque outfalls is similar to that of the Rio Grande from 1994 to 1996 (Wilcox, 1997).

$\mathrm{pH}$

The $\mathrm{pH}$ of water determines the solubility and biological availability of chemical constituents such as nutrients and heavy metals (Langmuir, 1997); for example, in addition to affecting how much and what form of nitrogen is most abundant in water, $\mathrm{pH}$ determines whether nitrogen can be used by aquatic life (Wetzel, 2001). In the case of heavy metals, $\mathrm{pH}$ can affect metal solubility and toxicity (Drever, 1997). The NM WQS for $\mathrm{pH}$ is a range from 6.6 to 9.0 standard units. In the stormwater samples, median $\mathrm{pH}$ values at the five outfalls during 2003-12 were within this range (table 8); however, the maximum $\mathrm{pH}$ measured at the North Diversion Channel outfall during 2003-12 exceeded the upper limit of the $\mathrm{pH}$ range.

\section{Specific Conductance}

Specific conductance, which is a measure of the ability of water to conduct an electric current, is directly related to the concentration of dissolved solids (Hem, 1992). The presence of charged ionic species (dissolved solids) makes water conductive. As the concentration of dissolved solids in water increases, the conductance of the water increases; therefore, the measurement of the conductance of water provides an indication of dissolved solids content (Hem, 1992). In the stormwater samples, median concentrations for specific conductance measured at the five outfalls during 2003-12 ranged from 93.50 to 261.00 microsiemens per centimeter at 25 degrees Celsius $\left(\mu \mathrm{S} / \mathrm{cm}\right.$ at $\left.25^{\circ} \mathrm{C}\right)$, with the highest median specific conductance concentrations observed at the South Diversion Channel $\left(217.00 \mu \mathrm{S} / \mathrm{cm}\right.$ at $\left.25^{\circ} \mathrm{C}\right)$ and San Jose Drain $\left(261.00 \mu \mathrm{S} / \mathrm{cm}\right.$ at $\left.25^{\circ} \mathrm{C}\right)$ outfalls (table 8$)$. 


\section{Summary of Urban Stormwater Quality in Albuquerque, New Mexico, 2003-12}

Table 8. Statistical summary of concentrations for physical and chemical constituents in urban stormwater samples from five outfalls in the Albuquerque metropolitan area, New Mexico, 2003-12.

[Full site names are provided in table 1. MAD, median absolute deviation; mg/L, milligrams per liter; -, no value; $\mathrm{CaCO}_{3}$, calcium carbonate; RGB, Rio Grande Basin; $\mu \mathrm{S} / \mathrm{cm}$ at $25^{\circ} \mathrm{C}$, microsiemens per centimeter at 25 degrees Celsius; $\mathrm{NC}$, not calculated; median and maximum concentrations presented in bold exceed a water-quality criterion concentration]

\begin{tabular}{|c|c|c|c|c|c|c|c|c|}
\hline \multirow[b]{2}{*}{ Constituent } & \multicolumn{2}{|c|}{ Water-quality criterion ${ }^{1}$} & \multirow{2}{*}{$\begin{array}{l}\text { Number of } \\
\text { analyses }\end{array}$} & \multirow[b]{2}{*}{ Minimum } & \multirow[b]{2}{*}{ Median } & \multirow[b]{2}{*}{ Mean } & \multirow[b]{2}{*}{ Maximum } & \multirow{2}{*}{$\begin{array}{l}\text { Upper MAD } \\
\text { outlier limi }\end{array}$} \\
\hline & Basis & $\begin{array}{c}\text { Criterion } \\
\text { concentration }\end{array}$ & & & & & & \\
\hline \multicolumn{9}{|c|}{ UR200 - South Diversion Channel } \\
\hline Chemical oxygen demand, mg/L & - & - & 25 & 78.00 & 171.00 & 191.72 & 560.00 & 477.80 \\
\hline Dissolved solids, $\mathrm{mg} / \mathrm{L}$ & RGB & 1,500 & 22 & 64.00 & 154.00 & 176.64 & 524.00 & 414.00 \\
\hline Specific conductance, $\mu \mathrm{S} / \mathrm{cm}$ at $25^{\circ} \mathrm{C}$ & - & - & 27 & 27.00 & 217.00 & 233.52 & 433.00 & 518.60 \\
\hline Suspended solids, $\mathrm{mg} / \mathrm{L}$ & - & - & 33 & 7.00 & 664.00 & $1,053.59$ & $6,980.00$ & $3,180.80$ \\
\hline Temperature, degrees Celsius & - & - & 19 & 6.00 & 23.00 & 20.50 & 36.20 & $\mathrm{NC}$ \\
\hline \multicolumn{9}{|c|}{ UR300 - San Antonio Arroyo } \\
\hline Biochemical oxygen demand, mg/L & - & - & 21 & 3.00 & 12.00 & 13.71 & 30.00 & 26.04 \\
\hline $\mathrm{pH}$, standard units & Primary contact & $6.6-9.0$ & 24 & 6.60 & 8.05 & 7.86 & 9.00 & 10.91 \\
\hline Specific conductance, $\mu \mathrm{S} / \mathrm{cm}$ at $25^{\circ} \mathrm{C}$ & - & - & 24 & 51.00 & 93.50 & 98.58 & 166.00 & 233.90 \\
\hline Suspended solids, mg/L & - & - & 24 & 12.00 & 36.50 & 163.15 & 892.00 & 156.10 \\
\hline Temperature, degrees Celsius & - & - & 23 & 4.10 & 18.00 & 15.70 & 26.00 & $\mathrm{NC}$ \\
\hline \multicolumn{9}{|c|}{ UR400B - Barelas Pump Station } \\
\hline Biochemical oxygen demand, $\mathrm{mg} / \mathrm{L}$ & - & - & 15 & 2.00 & 25.00 & 27.05 & 57.00 & 71.80 \\
\hline Chemical oxygen demand, mg/L & - & - & 22 & 34.00 & 224.00 & 239.36 & 690.00 & 601.00 \\
\hline Dissolved solids, $\mathrm{mg} / \mathrm{L}$ & RGB & 1,500 & 18 & 92.00 & 192.00 & 236.00 & 978.00 & 374.00 \\
\hline Hardness, $\mathrm{mg} / \mathrm{L}$ as $\mathrm{CaCO}_{3}$ & - & - & 24 & 52.70 & 91.60 & 89.85 & 130.00 & 167.52 \\
\hline $\mathrm{pH}$, standard units & Primary contact & $6.6-9.0$ & 23 & 6.7 & 7.40 & 7.40 & 8.10 & 8.96 \\
\hline Specific conductance, $\mu \mathrm{S} / \mathrm{cm}$ at $25^{\circ} \mathrm{C}$ & - & - & 23 & 113 & 203.00 & 293.00 & $1,790.00$ & 421.40 \\
\hline Hardness, $\mathrm{mg} / \mathrm{L}$ as $\mathrm{CaCO}_{3}$ & - & - & 25 & 41.00 & 100.00 & 104.64 & 176.00 & 166.04 \\
\hline $\mathrm{pH}$, standard units & Primary contact & $6.6-9.0$ & 30 & 6.80 & 7.75 & 7.71 & 8.60 & 9.31 \\
\hline Specific conductance, $\mu \mathrm{S} / \mathrm{cm}$ at $25^{\circ} \mathrm{C}$ & - & - & 30 & 83.00 & 261.00 & 306.37 & 776.00 & 692.60 \\
\hline Suspended solids, $\mathrm{mg} / \mathrm{L}$ & - & - & 34 & 24.00 & 404.00 & 633.74 & $3,948.00$ & $1,579.20$ \\
\hline Temperature, degrees Celsius & - & - & 13 & 8.00 & 22.80 & 19.00 & 27.00 & $\mathrm{NC}$ \\
\hline \multicolumn{9}{|c|}{ UR9900 - North Diversion Channel } \\
\hline Biochemical oxygen demand, $\mathrm{mg} / \mathrm{L}$ & - & - & 17 & 7.20 & 16.10 & 33.47 & 207.00 & 47.82 \\
\hline Chemical oxygen demand, mg/L & - & - & 21 & 34.00 & 220.00 & 262.90 & 770.00 & 719.20 \\
\hline Dissolved solids, $\mathrm{mg} / \mathrm{L}$ & RGB & 1,500 & 16 & 24.00 & 100.00 & 116.53 & 278.00 & 266.40 \\
\hline Hardness, $\mathrm{mg} / \mathrm{L}$ as $\mathrm{CaCO}_{3}$ & - & - & 19 & 33.70 & 67.30 & 72.20 & 157.00 & 143.74 \\
\hline $\mathrm{pH}$, standard units & Primary contact & $6.6-9.0$ & 24 & 6.80 & 8.20 & 8.05 & 9.30 & 10.54 \\
\hline Specific conductance, $\mu \mathrm{S} / \mathrm{cm}$ at $25^{\circ} \mathrm{C}$ & - & - & 23 & 59.00 & 98.00 & 126.13 & 306.00 & 269.60 \\
\hline Suspended solids, mg/L & - & - & 23 & 68.00 & $1,520.00$ & $1,934.87$ & $6,160.00$ & $4,536.00$ \\
\hline Temperature, degrees Celsius & - & - & 27 & 6.00 & 19.00 & 17.50 & 25.00 & $\mathrm{NC}$ \\
\hline
\end{tabular}

${ }^{1}$ New Mexico water-quality standards (NM WQSs) as described in State of New Mexico Standards for Interstate and Intrastate Surface Waters (20.6.4 New Mexico Administrative Code). 


\section{Dissolved Solids}

Dissolved solids (sometimes referred to as "total dissolved solids") naturally occur in streams as a result of weathering and dissolution of soils and rocks. Major ions, such as bicarbonate, calcium, chloride, magnesium, potassium, sodium, and sulfate, constitute the greatest percentage of the dissolved solids in water and are an indicator of salinity (Hem, 1992). The highest mean concentration of dissolved solids was detected at the Barelas Pump Station $(236.00 \mathrm{mg} / \mathrm{L})$ outfall, and the lowest mean concentration of dissolved solids was detected at the San Antonio Arroyo outfall $(88.00 \mathrm{mg} / \mathrm{L})$ outfall (table 8; fig. 2). Wilcox (1997) reported a mean dissolved solids concentration for the Rio Grande at San Felipe (located approximately $20 \mathrm{mi}$ upstream from the North Diversion Channel) of $213 \mathrm{mg} / \mathrm{L}$ from 1994 to 1996, which is similar to the mean dissolved solids concentrations measured at the five Albuquerque outfalls (table 8). Maximum dissolved solids concentrations measured in stormwater samples at the five outfalls did not exceed the NM WQS of $1,500 \mathrm{mg} / \mathrm{L}$ for the Rio Grande Basin.

\section{Suspended Solids}

Suspended solids (sometimes referred to as "total suspended solids") can affect water quality in several ways.

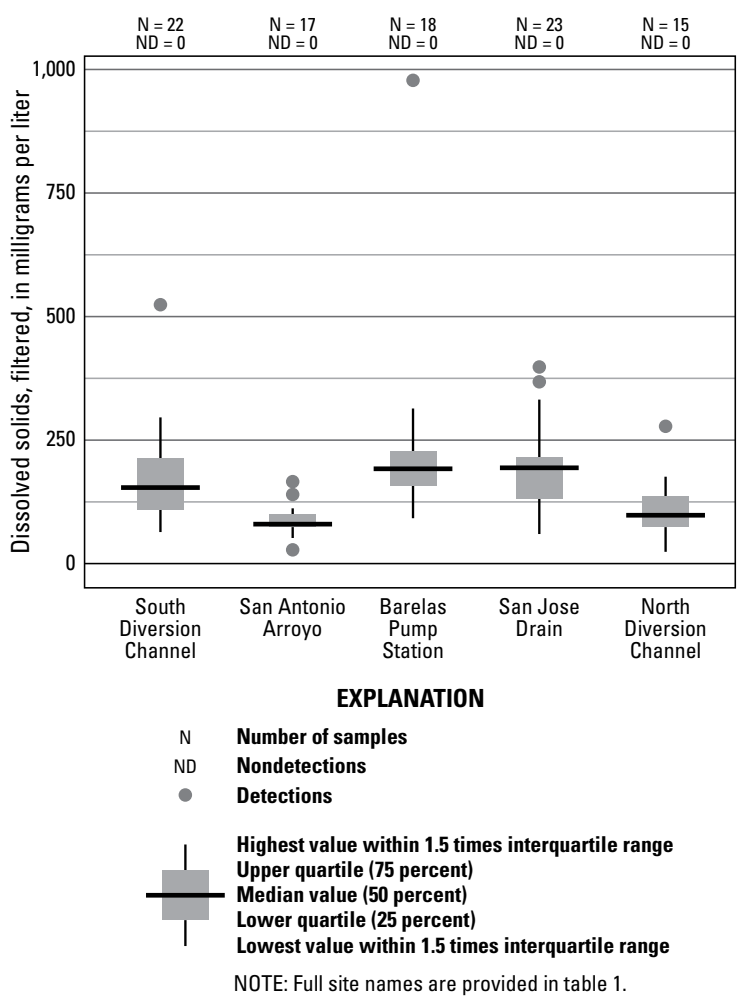

Figure 2. Dissolved solids concentrations in urban stormwater samples from five outfalls in the Albuquerque metropolitan area, New Mexico, 2003-12.
High suspended solids concentrations can adversely affect recreational uses and aesthetics of water. Many trace elements, some organic compounds including pesticides, and some nutrients are effectively sorbed onto and transported with suspended solids (Drever, 1997).

Biological communities can be adversely affected in environments having a high suspended solids concentration because of limited light penetration (Wetzel, 2001). In the stormwater samples, median concentrations for suspended solids ranged from $36.50 \mathrm{mg} / \mathrm{L}$ at the San Antonio Arroyo outfall to $1,520.00 \mathrm{mg} / \mathrm{L}$ at the North Diversion Channel outfall (table 8). Anderholm and others (1995) reported a median suspended solid concentration for the Rio Grande at Albuquerque streamgage of $637 \mathrm{mg} / \mathrm{L}$ from 1972 to 1990 , which is considerably lower than the median suspended solids concentration measured in the North Diversion Channel outfall during this study (fig. 3). The outfalls typically were sampled only during periods of high flow - when water generally carries higher loads than during periods of low flow — which may account for the high median suspended solids concentrations observed at the North Diversion Channel outfall in comparison to the median suspended solids concentrations reported for the Rio Grande at Albuquerque streamgage (Anderholm and others, 1995).

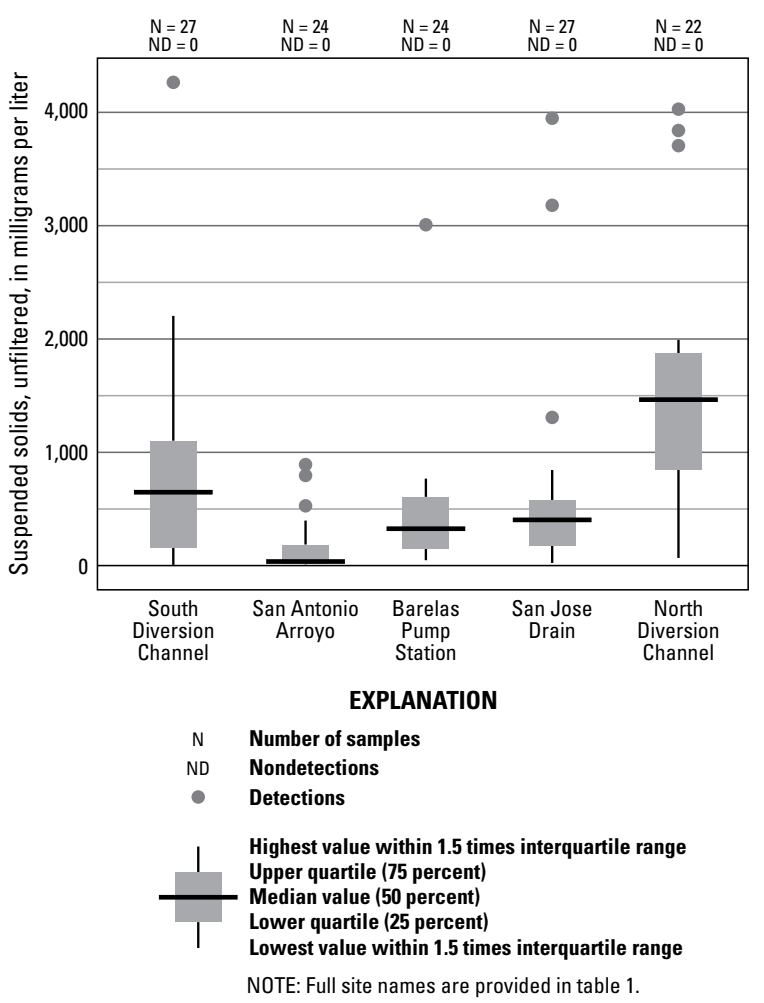

Figure 3. Suspended solids concentrations in urban stormwater samples from five outfalls in the Albuquerque metropolitan area, New Mexico, 2003-12. 


\section{Biochemical Oxygen Demand and Chemical Oxygen Demand}

Urban stormwater often contains organic materials that are decomposed by microorganisms, which consume oxygen in the decomposition process. BOD is the amount of oxygen consumed by microorganisms in the decomposition process. COD is similar in function to BOD in that both can be used as an indicator of the amount of organic compounds available for decomposition in water; however, COD is a less specific indicator because it measures everything that can be chemically oxidized rather than only levels of biological activity (Tchobanoglous and Schroeder, 1985). No specific water-quality standard exists for BOD or COD. The highest median BOD concentrations were detected at the Barelas Pump Station (25.00 mg/L) and San Jose Drain (23.50 mg/L) outfalls, and the lowest median concentration was detected at the San Antonio Arroyo outfall (12.00 mg/L) (fig. 4).

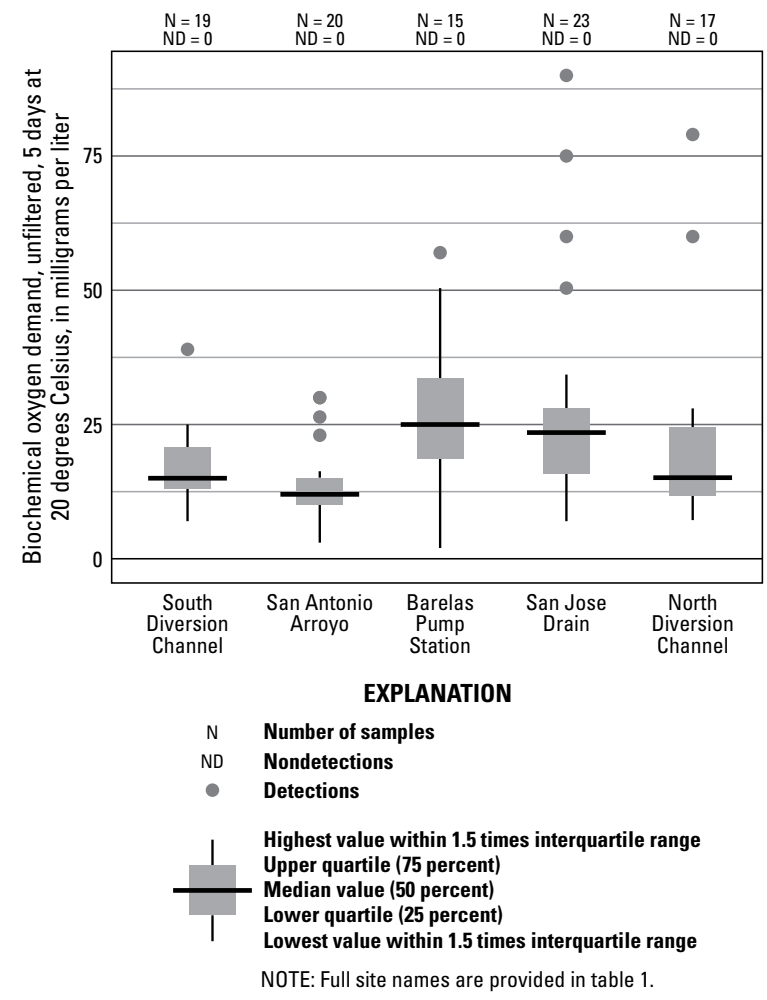

Figure 4. Biochemical oxygen demand concentrations in urban stormwater samples from five outfalls in the Albuquerque metropolitan area, New Mexico, 2003-12.

\section{Nutrients}

Although nutrients such as nitrogen and phosphorus are a basic need of plants in terrestrial and aquatic ecosystems, excessive nutrients can have harmful effects on stream health, including excessive algal growth and eutrophication (Carpenter and others, 1998; Galloway and others, 2003). NM WQSs exist for nitrates, nitrites, and ammonia but not for phosphorus (20.6.4 NMAC). Nitrogen-based nutrient (ammonia, total and dissolved nitrogen) concentrations measured at the outfalls (table 9) are similar to those found in the Rio Grande from 1972 to 1990 (Anderholm, 1995). Total phosphorus concentrations measured at the outfalls (table 9) are higher than those found in the Rio Grande from 1972 to 1990 (Anderholm, 1995).

\section{Nitrogen-Based Nutrients}

There is no NM WQS for ammonia in water for domestic water supply, but there is an NM WQS for ammonia in water for freshwater aquatic life criteria expressed as a function of $\mathrm{pH}$, temperature, and the presence or absence of fish in early life stages. The NM WQSs for ammonia concentrations are $12.1 \mathrm{mg} / \mathrm{L}$ for acute toxicity and $3.09 \mathrm{mg} / \mathrm{L}$ for chronic toxicity based on a $\mathrm{pH}$ of 7.8 , a water temperature of $15^{\circ} \mathrm{C}$ and greater (based on the overall median $\mathrm{pH}$ and temperature values at the outfalls), and no presence of fish in early life stages in the water. The median and maximum concentrations for ammonia measured in stormwater samples collected from the outfalls during 2003-12 did not exceed the NM WQSs for acute or chronic toxicity for aquatic life. In the stormwater samples, median concentrations for total ammonia (reported as ammonia, unfiltered, as nitrogen [N]; table 9) ranged from $0.25 \mathrm{mg} / \mathrm{L}$ (South Diversion Channel outfall) to $0.63 \mathrm{mg} / \mathrm{L}$ (Barelas Pump Station outfall).

Total nitrogen, the sum of total Kjeldahl nitrogen (ammonia, organic nitrogen, and reduced nitrogen) and nitrate plus nitrite, can be determined as the sum of the concentrations for organic nitrogen compounds, free ammonia, and nitrate. In the stormwater samples, median concentrations for unfiltered total nitrogen ranged from $1.59 \mathrm{mg} / \mathrm{L}$ (San Antonio Arroyo outfall) to $4.45 \mathrm{mg} / \mathrm{L}$ (San Jose Drain outfall). Anderholm and others (1995) reported a median total nitrogen concentration of $1.8 \mathrm{mg} / \mathrm{L}$ for the Rio Grande at Isleta streamgage from 1972 to 1990 .

Median concentrations for dissolved nitrate did not exceed the NM WQS of $10 \mathrm{mg} / \mathrm{L}$ of nitrate in waters for domestic water supply (20.6.4 NMAC) in stormwater samples collected from the outfalls. Median dissolved nitrate concentrations ranged from $0.49 \mathrm{mg} / \mathrm{L}$ (San Antonio Arroyo outfall) to $0.86 \mathrm{mg} / \mathrm{L}$ (Barelas Pump Station outfall) (table 9). 
Table 9. Statistical summary of concentrations for nutrients in urban stormwater samples from five outfalls in the Albuquerque metropolitan area, New Mexico, 2003-12.

[Full site names are provided in table 1. mg/L, milligrams per liter; MAD, median absolute deviation; N, nitrogen; NM DWS, New Mexico domestic watersupply standard; P, phosphorus; -, no value. Freshwater acute aquatic life criteria for total (unfiltered) ammonia are expressed as a function of $\mathrm{pH}$ and the presence or absence of salmonids; values displayed correspond to a $\mathrm{pH}$ of 7.8 and absence of salmonids based on the overall median and average $\mathrm{pH}$ and absence of salmonids at the outfalls. Freshwater chronic aquatic life criteria for total ammonia are expressed as a function of $\mathrm{pH}$ and water temperature in the water body; values displayed correspond to a $\mathrm{pH}$ of 7.8 and temperature greater than 15 degrees Celsius based on the overall median and average $\mathrm{pH}$ and temperature values at the outfalls; for aquatic life concentrations, the first listed value is the acute concentration limit and the second listed value is the chronic concentration limit]

\begin{tabular}{|c|c|c|c|c|c|c|c|c|}
\hline \multirow[b]{2}{*}{ Constituent } & \multicolumn{2}{|c|}{ Water-quality criterion' ${ }^{1}$} & \multirow[b]{2}{*}{$\begin{array}{l}\text { Number of } \\
\text { analyses }\end{array}$} & \multirow[b]{2}{*}{$\begin{array}{l}\text { Minimum } \\
\text { (mg/L) }\end{array}$} & \multirow[b]{2}{*}{$\begin{array}{l}\text { Median } \\
\text { (mg/L) }\end{array}$} & \multirow[b]{2}{*}{$\begin{array}{l}\text { Mean } \\
(\mathrm{mg} / \mathrm{L})\end{array}$} & \multirow[b]{2}{*}{$\begin{array}{c}\text { Maximum } \\
(\mathrm{mg} / \mathrm{L})\end{array}$} & \multirow{2}{*}{$\begin{array}{c}\text { Upper } \\
\text { MAD } \\
\text { outlier } \\
\text { limit } \\
\text { (mg/L) }\end{array}$} \\
\hline & Basis & $\begin{array}{c}\text { Concentration } \\
\text { (mg/L) }\end{array}$ & & & & & & \\
\hline \multicolumn{9}{|c|}{ UR-200 - South Diversion Channel } \\
\hline Ammonia + organic nitrogen, filtered, as $\mathrm{N}$ & - & - & 22 & 0.24 & 1.02 & 1.01 & 2.10 & 2.45 \\
\hline Ammonia + organic nitrogen, unfiltered as $\mathrm{N}$ & - & - & 28 & 0.27 & 2.12 & 2.50 & 6.70 & 6.59 \\
\hline Ammonia, unfiltered, as $\mathrm{N}$ & Aquatic life & $12.1 / 3.09$ & 28 & 0.10 & 0.25 & 0.29 & 0.84 & 0.84 \\
\hline Nitrate plus nitrite, filtered, as $\mathrm{N}$ & - & - & 26 & 0.10 & 0.62 & 0.68 & 2.27 & 1.47 \\
\hline Nitrate plus nitrite, unfiltered, as $\mathrm{N}$ & $\begin{array}{l}\text { Livestock } \\
\text { watering }\end{array}$ & 132 & 26 & 0.10 & 0.58 & 0.65 & 2.29 & 1.36 \\
\hline Nitrate, filtered, as $\mathrm{N}$ & NM DWS & 10 & 22 & 0.05 & 0.62 & 0.86 & 4.64 & 1.63 \\
\hline Total nitrogen, unfiltered, as $\mathrm{N}$ & - & - & 26 & 0.72 & 2.66 & 2.95 & 6.63 & 7.76 \\
\hline \multicolumn{9}{|c|}{ UR-300 - San Antonio Arroyo } \\
\hline Ammonia + organic nitrogen, filtered, as $\mathrm{N}$ & - & - & 19 & 0.40 & 0.84 & 0.88 & 1.73 & 1.72 \\
\hline Ammonia + organic nitrogen, unfiltered as $\mathrm{N}$ & - & - & 23 & 0.55 & 1.20 & 1.18 & 1.92 & 2.24 \\
\hline Ammonia, filtered, as $\mathrm{N}$ & - & - & 23 & 0.10 & 0.28 & 0.29 & 0.61 & 0.96 \\
\hline Ammonia, unfiltered, as $\mathrm{N}$ & Aquatic life & $12.1 / 3.09$ & 23 & 0.10 & 0.30 & 0.29 & 0.59 & 0.98 \\
\hline Nitrate plus nitrite, filtered, as $\mathrm{N}$ & - & - & 24 & 0.14 & 0.42 & 0.42 & 0.79 & 0.84 \\
\hline Nitrate plus nitrite, unfiltered, as $\mathrm{N}$ & $\begin{array}{l}\text { Livestock } \\
\text { watering }\end{array}$ & 132 & 24 & 0.14 & 0.42 & 0.43 & 0.79 & 0.81 \\
\hline Nitrate, filtered, as $\mathrm{N}$ & NM DWS & 10 & 18 & 0.15 & 0.49 & 0.58 & 2.19 & 1.11 \\
\hline Ammonia + organic nitrogen, unfiltered as $\mathrm{N}$ & - & - & 22 & 1.22 & 3.44 & 3.61 & 6.86 & 10.30 \\
\hline Ammonia, filtered, as $\mathrm{N}$ & - & - & 22 & 0.15 & 0.61 & 0.66 & 1.67 & 2.20 \\
\hline Ammonia, unfiltered, as $\mathrm{N}$ & Aquatic life & $12.1 / 3.09$ & 22 & 0.18 & 0.63 & 0.67 & 1.72 & 2.22 \\
\hline Nitrate plus nitrite, filtered, as $\mathrm{N}$ & - & - & 21 & 0.10 & 0.82 & 0.87 & 2.00 & 1.76 \\
\hline Nitrate plus nitrite, unfiltered, as $\mathrm{N}$ & $\begin{array}{l}\text { Livestock } \\
\text { watering }\end{array}$ & 132 & 20 & 0.10 & 0.82 & 0.86 & 2.00 & 1.81 \\
\hline Nitrate, filtered, as $\mathrm{N}$ & NM DWS & 10 & 20 & 0.29 & 0.86 & 1.02 & 2.05 & 2.37 \\
\hline Orthophosphate, filtered, as P & - & - & 13 & 0.04 & 0.13 & 0.18 & 0.44 & 0.39 \\
\hline Phosphorus, filtered, as P & - & - & 10 & 0.06 & 0.21 & 0.21 & 0.41 & 0.60 \\
\hline Phosphorus, unfiltered, as P & - & - & 22 & 0.29 & 0.71 & 0.82 & 2.50 & 1.77 \\
\hline Total nitrogen, filtered, as $\mathrm{N}$ & - & - & 21 & 1.10 & 2.91 & 2.82 & 5.62 & 7.12 \\
\hline Total nitrogen, unfiltered, as $\mathrm{N}$ & - & - & 23 & 2.05 & 4.09 & 4.39 & 8.46 & 11.47 \\
\hline
\end{tabular}




\section{Summary of Urban Stormwater Quality in Albuquerque, New Mexico, 2003-12}

Table 9. Statistical summary of concentrations for nutrients in urban stormwater samples from five outfalls in the Albuquerque metropolitan area, New Mexico, 2003-12.-Continued

[Full site names are provided in table 1. mg/L, milligrams per liter; MAD, median absolute deviation; N, nitrogen; NM DWS, New Mexico domestic watersupply standard; P, phosphorus; -, no value. Freshwater acute aquatic life criteria for total (unfiltered) ammonia are expressed as a function of $\mathrm{pH}$ and the presence or absence of salmonids; values displayed correspond to a $\mathrm{pH}$ of 7.8 and absence of salmonids based on the overall median and average $\mathrm{pH}$ and absence of salmonids at the outfalls. Freshwater chronic aquatic life criteria for total ammonia are expressed as a function of $\mathrm{pH}$ and water temperature in the water body; values displayed correspond to a $\mathrm{pH}$ of 7.8 and temperature greater than 15 degrees Celsius based on the overall median and average $\mathrm{pH}$ and temperature values at the outfalls; for aquatic life concentrations, the first listed value is the acute concentration limit and the second listed value is the chronic concentration limit]

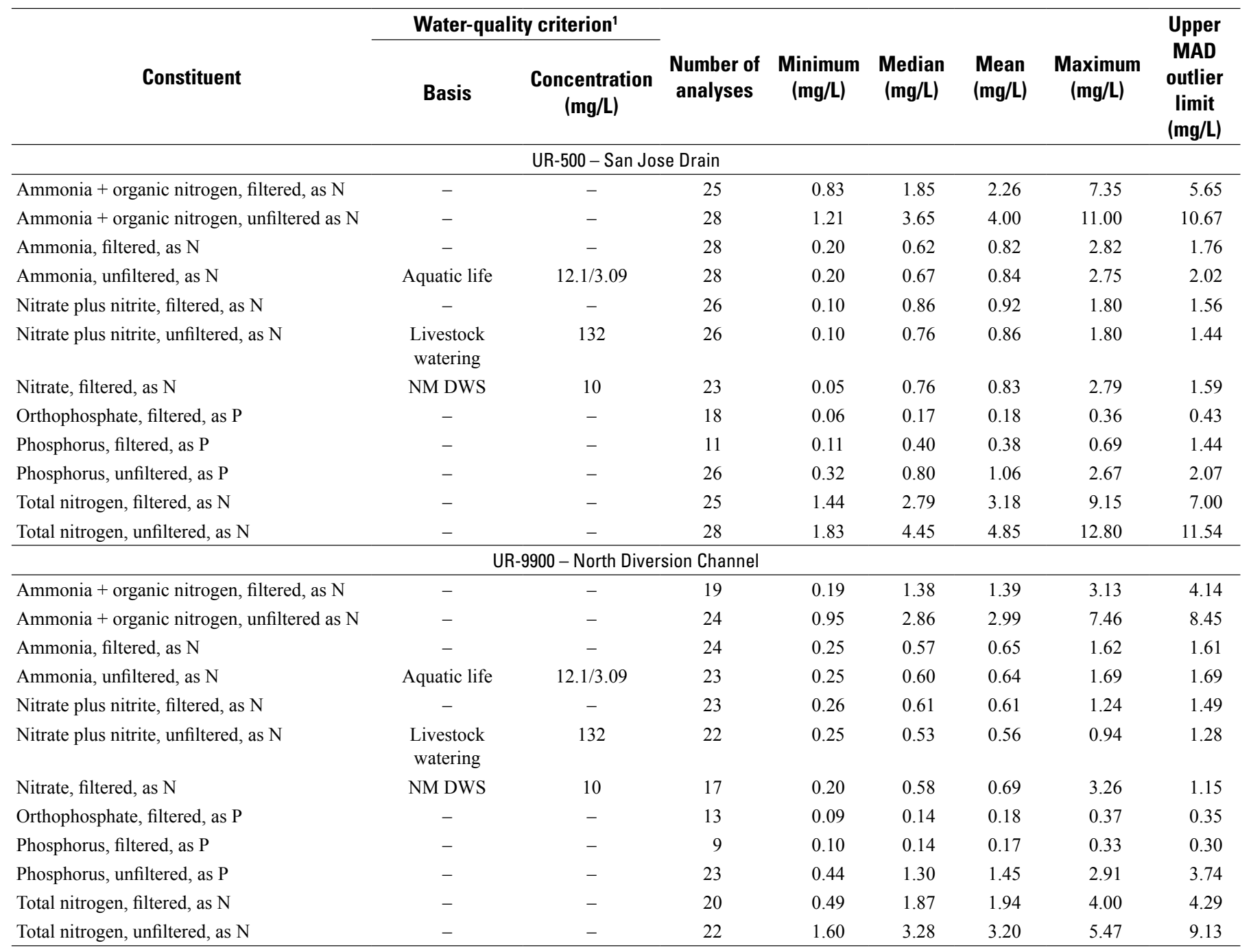

${ }^{1}$ New Mexico water-quality standards (NM WQSs) as described in State of New Mexico Standards for Interstate and Intrastate Surface Waters (20.6.4 New Mexico Administrative Code). 


\section{Phosphorus}

Sources of phosphorus in the aquatic environment can include phosphate fertilizers, animal waste, and erosion of sediments (Hem, 1992). There is no NM WQS for phosphorus in water for domestic water supply. Boxplots of total phosphorus concentrations (reported as phosphorus, unfiltered) measured at the outfalls during 2003-12 are presented in figure 5. Median concentrations for total (unfiltered) phosphorus ranged from $0.25 \mathrm{mg} / \mathrm{L}$ at the San Antonio Arroyo outfall to $1.30 \mathrm{mg} / \mathrm{L}$ at the North Diversion Channel (table 9). Anderholm and others (1995) reported a median total phosphorus concentration of $0.09 \mathrm{mg} / \mathrm{L}$ for the Rio Grande at Albuquerque streamgage from 1972 to 1990 . Outfalls were typically sampled only during periods of high flow, which may account for the high median phosphorus concentrations observed at the North Diversion Channel outfall in comparison to median phosphorus concentrations reported for the Rio Grande at Albuquerque streamgage (Anderholm and others, 1995). Particulate phosphorus, the portion of the phosphorus sorbed to suspended solids, can account for up to 95 percent of the total phosphorous concentration and usually increases during high flow periods, when there is a larger volume of suspended solids (Hem, 1992).

\section{Major lons}

Major ions are common constituents dissolved in most natural waters and include calcium, chloride, magnesium, potassium, sodium, and sulfate. Dissolved concentrations for chloride and sulfate have NM WQSs for aquatic life (20.6.4 NMAC) and were analyzed on at least 25 different occasions at each of the five outfalls (figs. 6 and 7). Calcium, magnesium, potassium, and sodium do not have specific waterquality standards. Data for calcium, magnesium, potassium, and sodium were limited and were analyzed no more than three times at any one outfall.

Most major ion concentrations in the stormwater samples in this study were similar to the major ion concentrations found in the Rio Grande (table 10), which are based on major ion data compiled from the USGS NWIS database for the Rio Grande at Albuquerque streamgage (fig. 1) from 1969 to 1998. Median chloride concentrations measured in stormwater samples in this study were comparable to median chloride concentrations reported for samples from the Rio Grande at Albuquerque streamgage. Median sulfate concentrations measured in stormwater samples in this study tended to be lower than the median sulfate concentrations reported for samples from the Rio Grande at Albuquerque streamgage. Maximum sulfate concentrations measured in stormwater samples in this study did not exceed the NM WQS for the Rio Grande Basin of 500 $\mathrm{mg} / \mathrm{L}$ at any site. Maximum chloride concentrations ranged from 14.49 to $494.00 \mathrm{mg} / \mathrm{L}$ (fig. 6; table 10), with the highest maximum concentration for chloride occurring at the Barelas Pump Station outfall exceeding the NM WQS for the Rio Grande Basin of $250 \mathrm{mg} / \mathrm{L}$; however, this value was determined to be an outlier because the second highest concentration at this site was $80.80 \mathrm{mg} / \mathrm{L}$ (fig. 6). The highest median chloride and sulfate concentrations were detected at the San Jose Drain and Barelas Pump Station outfalls (figs. 6 and 7; table 10), which drain basins with a high degree of urban development. The lowest median chloride and sulfate concentrations were detected at the San Antonio Arroyo outfall (figs. 6 and 7), which drains the basin with comparatively less development.

\section{Metals}

There are NM WQSs for most of the metals analyzed for in this study (20.6.4 NMAC). The NM WQSs for most metals are based on dissolved constituent concentrations. The NM WQS freshwater aquatic life criteria for some metals (including aluminum, chromium [VI], lead, mercury, nickel, and silver) are expressed as a function of total hardness. The aquatic life criteria values displayed in table 11 correspond to a total hardness of $80 \mathrm{mg} / \mathrm{L}$ on the basis of the overall median and mean hardness values at the outfalls. Dissolved metal concentrations in stormwater samples from the five outfalls in this study are similar than those in samples from the Rio Grande from 1994 to 1996 (Wilcox, 1997).

Dissolved aluminum, dissolved arsenic, dissolved chromium (VI), and dissolved lead were the only metals detected with maximum concentrations that exceeded NM WQSs in the stormwater samples. Maximum dissolved aluminum concentrations exceeded the NM WQS chronic aquatic life criterion of $87 \mu \mathrm{g} / \mathrm{L}$ in stormwater samples from all sites except for the South Diversion Channel outfall. The highest maximum concentrations for dissolved aluminum were detected at the North Diversion Channel $(5,540.00 \mu \mathrm{g} / \mathrm{L})$ and Barelas Pump Station (1,910.00 $\mu \mathrm{g} / \mathrm{L}$ ) outfalls (table 11) but were determined to be outliers because they exceeded the upper MAD outlier limit. The second and third highest maximum concentrations of dissolved aluminum observed at the North Diversion Channel $(44.30 \mu \mathrm{g} / \mathrm{L})$ and Barelas Pump Station $(37.70 \mu \mathrm{g} / \mathrm{L})$ outfalls were below the standard (fig. 8).

Maximum dissolved arsenic concentrations in stormwater samples from the South Diversion Channel outfall exceeded the NM WQS chronic aquatic life criterion of $10 \mu \mathrm{g} / \mathrm{L}$ (table 11). The median concentrations for dissolved arsenic were below the NM WQS for aquatic life toxicity at each outfall.

Maximum dissolved chromium (VI) concentrations in stormwater samples from all sites except for the San Antonio Arroyo and the North Diversion Channel outfalls exceeded the chronic aquatic life criterion of $11 \mu \mathrm{g} / \mathrm{L}$ (table 11). The median concentrations for dissolved chromium (VI) were below the NM WQS for aquatic life toxicity at each outfall.

Maximum dissolved lead concentrations in stormwater samples from all sites were at or above the chronic aquatic life criterion of $2 \mu \mathrm{g} / \mathrm{L}$ (table 11 ). In the stormwater samples, maximum concentrations for dissolved lead ranged from $2.00 \mu \mathrm{g} / \mathrm{L}$ (South Diversion Channel outfall) to $6.93 \mu \mathrm{g} / \mathrm{L}$ (North Diversion Channel outfall) (table 11). The median concentrations for dissolved lead were at or below the NM WQS for aquatic life toxicity at each outfall. 


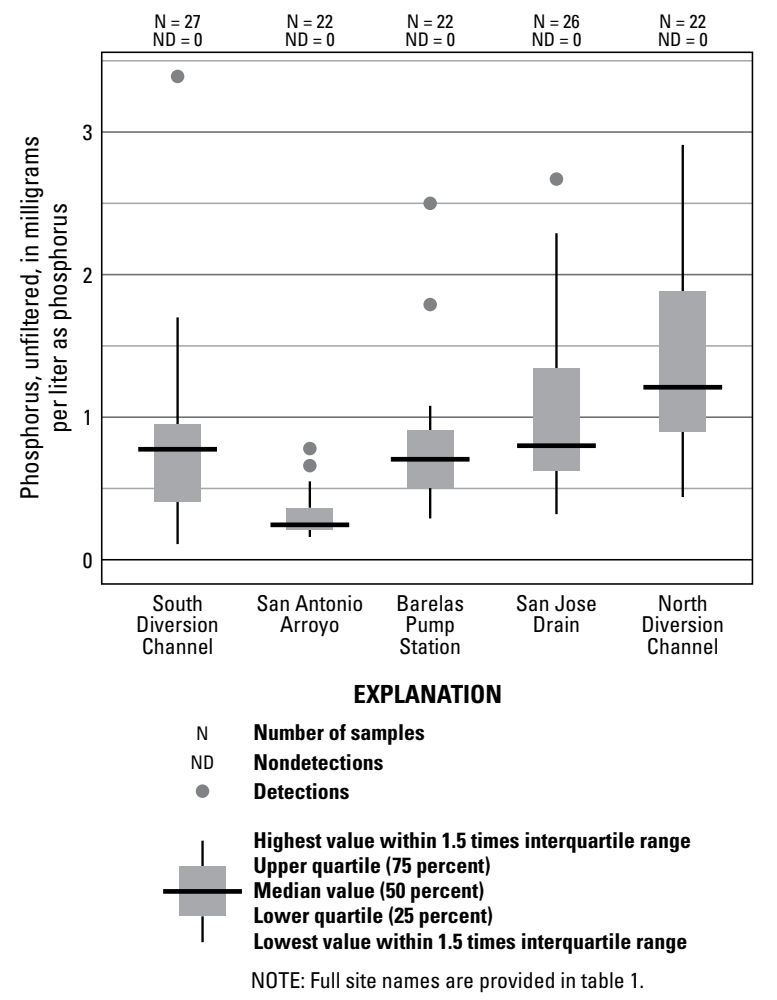

Figure 5. Total phosphorus concentrations in urban stormwater samples from five outfalls in the Albuquerque metropolitan area, New Mexico, 2003-12.

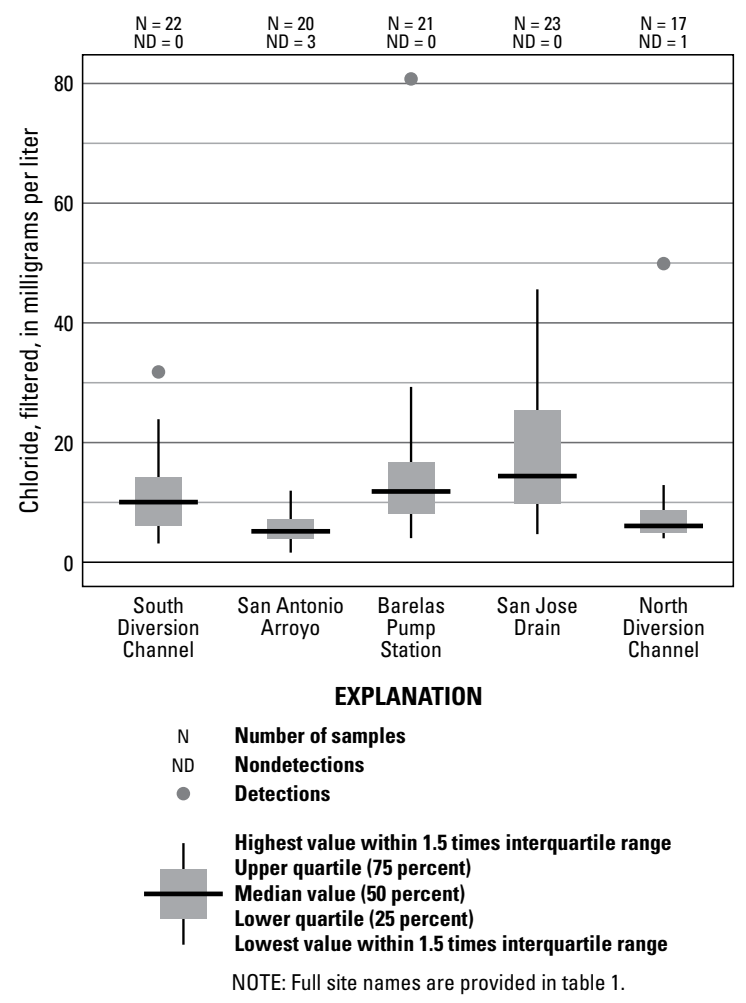

Figure 6. Chloride concentrations in urban stormwater samples from five outfalls in the Albuquerque metropolitan area, New Mexico, 2003-12.

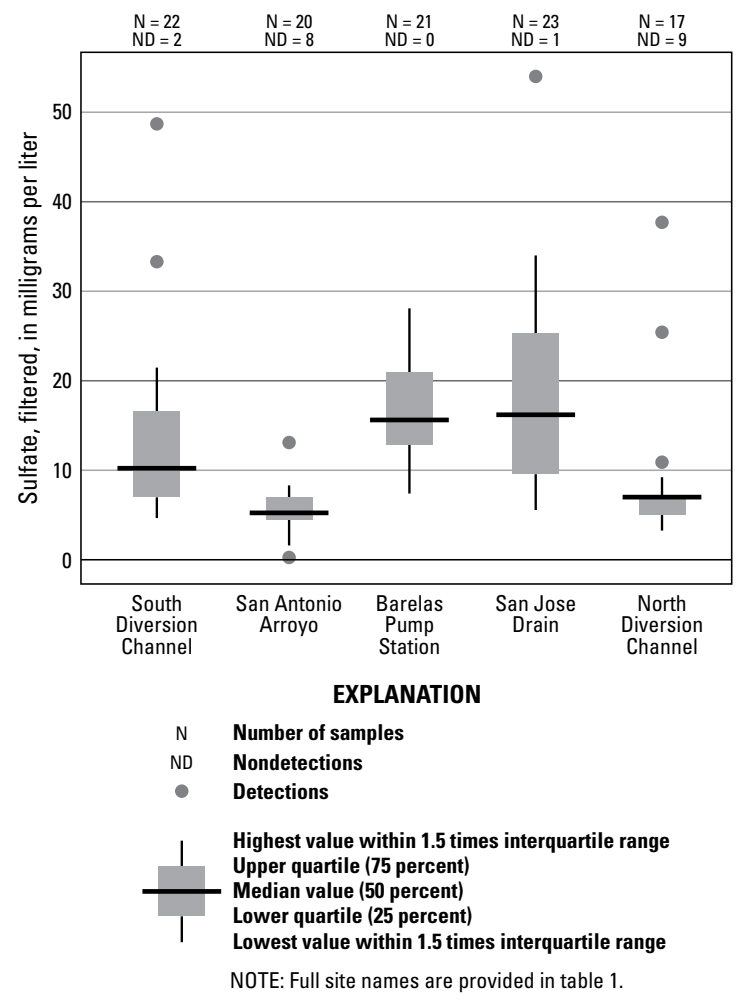

Figure 7. Sulfate concentrations in urban stormwater samples from five outfalls in the Albuquerque metropolitan area, New Mexico, 2003-12.

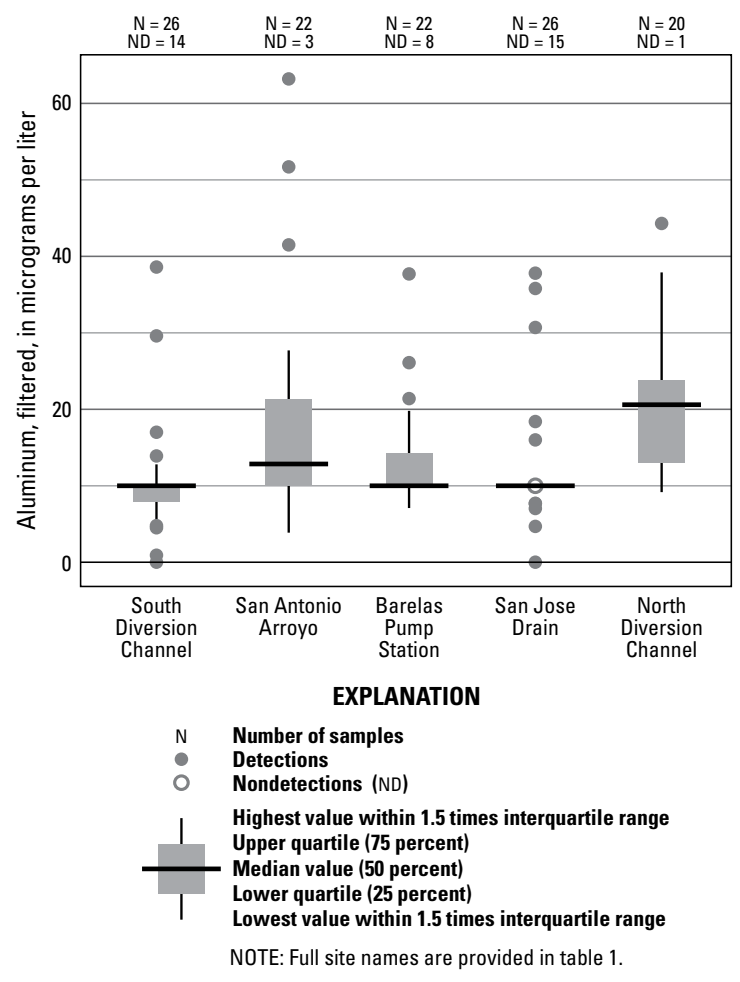

Figure 8. Dissolved aluminum concentrations in urban stormwater samples from five outfalls in the Albuquerque metropolitan area, New Mexico, 2003-12. 
Table 10. Statistical summary of concentrations for major ions in urban stormwater samples from five outfalls in the Albuquerque metropolitan area, New Mexico, 2003-12.

[Full site names of Albuquerque metropolitan area sites are provided in table 1. mg/L, milligrams per liter; MAD, mean absolute deviation; -, no value; NC, not calculated; RGB, Rio Grande Basin; NWIS, National Water Information System; median and maximum concentrations presented in bold exceed a water-quality criterion concentration]

\begin{tabular}{|c|c|c|c|c|c|c|c|c|}
\hline \multirow{2}{*}{$\begin{array}{c}\text { Constituent } \\
\text { (mg/L) }\end{array}$} & \multicolumn{2}{|c|}{ Water-quality criterion' ${ }^{1}$} & \multirow[b]{2}{*}{$\begin{array}{l}\text { Number of } \\
\text { analyses }\end{array}$} & \multirow[b]{2}{*}{$\begin{array}{c}\text { Minimum } \\
\text { (mg/L) }\end{array}$} & \multirow[b]{2}{*}{$\begin{array}{l}\text { Median } \\
\text { (mg/L) }\end{array}$} & \multirow[b]{2}{*}{$\begin{array}{l}\text { Mean } \\
(\mathrm{mg} / \mathrm{L})\end{array}$} & \multirow[b]{2}{*}{$\begin{array}{l}\text { Maximum } \\
\text { (mg/L) }\end{array}$} & \multirow{2}{*}{$\begin{array}{c}\text { Upper MAD } \\
\text { outlier limit } \\
\text { (mg/L) }\end{array}$} \\
\hline & Basis & $\begin{array}{c}\text { Criterion } \\
\text { concentration }\end{array}$ & & & & & & \\
\hline \multicolumn{9}{|c|}{ UR-200 - South Diversion Channel } \\
\hline Chloride, filtered & RGB & 250 & 22 & 3.14 & 10.05 & 11.35 & 31.80 & 32.25 \\
\hline Magnesium, unfiltered & - & - & 1 & 3.43 & 3.43 & 3.43 & 3.43 & 3.43 \\
\hline Sulfate, filtered & RGB & 500 & 22 & 4.66 & 10.23 & 13.36 & 48.70 & 29.21 \\
\hline \multicolumn{9}{|c|}{ UR-300 - San Antonio Arroyo } \\
\hline Calcium & - & - & 1 & 8.66 & 8.66 & 8.66 & 8.66 & 8.66 \\
\hline Chloride, filtered & RGB & 250 & 21 & 1.61 & 5.28 & 5.97 & 14.49 & 11.94 \\
\hline Magnesium, unfiltered & - & - & 1 & 0.86 & 0.86 & 0.86 & 0.86 & 0.86 \\
\hline \multicolumn{9}{|c|}{ UR-400B - Barelas Pump Station } \\
\hline Calcium & No data & No data & No data & No data & No data & No data & No data & No data \\
\hline Chloride, filtered & RGB & 250 & 21 & 4.03 & 12.46 & 39.08 & 494.00 & 36.54 \\
\hline Magnesium & No data & No data & No data & No data & No data & No data & No data & No data \\
\hline Potassium & No data & No data & No data & No data & No data & No data & No data & No data \\
\hline Sodium & No data & No data & No data & No data & No data & No data & No data & No data \\
\hline Sulfate, filtered & RGB & 500 & 21 & 7.40 & 15.62 & 16.87 & 28.09 & 39.64 \\
\hline \multicolumn{9}{|c|}{ UR-500 - San Jose Drain } \\
\hline Calcium & No data & No data & No data & No data & No data & No data & No data & No data \\
\hline Chloride, filtered & RGB & 250 & 23 & 4.70 & 14.40 & 18.74 & 45.60 & 45.96 \\
\hline Magnesium & No data & No data & No data & No data & No data & No data & No data & No data \\
\hline Magnesium, filtered & - & - & 1 & 1.44 & 1.44 & 1.44 & 1.44 & 1.44 \\
\hline Magnesium, unfiltered & - & - & 1 & 8.24 & 8.24 & 8.24 & 8.24 & 8.24 \\
\hline Potassium, filtered & - & - & 1 & 5.67 & 5.67 & 5.67 & 5.67 & 5.67 \\
\hline Sodium, filtered & - & - & 1 & 32.09 & 32.09 & 32.09 & 32.09 & 32.09 \\
\hline Sulfate, filtered & RGB & 500 & 18 & 3.26 & 7.00 & 9.52 & 37.70 & 17.40 \\
\hline \multicolumn{9}{|c|}{ Rio Grande at Albuquerque (station 08330000)² } \\
\hline Calcium, filtered & - & - & 40 & 27.00 & 41.00 & 42.28 & 70.00 & $\mathrm{NC}$ \\
\hline Chloride, filtered & RGB & 250 & 39 & 4.00 & 9.90 & 11.24 & 37.00 & $\mathrm{NC}$ \\
\hline Magnesium, filtered & - & - & 40 & 4.80 & 7.25 & 7.26 & 9.70 & $\mathrm{NC}$ \\
\hline Potassium, filtered & - & - & 39 & 2.20 & 3.10 & 3.28 & 7.00 & $\mathrm{NC}$ \\
\hline Sodium, filtered & - & - & 40 & 13.00 & 25.00 & 26.10 & 60.00 & $\mathrm{NC}$ \\
\hline Sulfate, filtered & RGB & 500 & 39 & 36.00 & 62.00 & 66.90 & 150.00 & $\mathrm{NC}$ \\
\hline
\end{tabular}

${ }^{1}$ New Mexico water-quality standards (NM WQSs) as described in State of New Mexico Standards for Interstate and Intrastate Surface Waters (20.6.4 New Mexico Administrative Code).

${ }^{2}$ Concentrations are based on major ion data compiled from the U.S. Geological Survey National Water Information System database for the Rio Grande at Albuquerque streamgage from 1969 to 1998. 
Table 11. Statistical summary of concentrations for dissolved metals in urban stormwater samples from five outfalls and the Rio Grande at Albuquerque in the Albuquerque metropolitan area, New Mexico, 2003-12.

[Full site names are provided in table 1. $\mu \mathrm{g} / \mathrm{L}$, micrograms per liter; MAD, mean absolute deviation; NM DWS, New Mexico domestic water-supply standard; $<$, less than. Freshwater aquatic life criteria for metals are expressed as a function of total hardness (milligrams per liter as $\mathrm{CaCO}_{3}$ ) in the water body; values displayed correspond to a total hardness of 80 milligrams per liter as $\mathrm{CaCO}_{3}$, based on the overall median and average hardness values at the outfalls; for aquatic life concentrations, the first listed value is the acute concentration limit, and the second listed value is the chronic concentration limit; median and maximum concentrations presented in bold exceed a water-quality criterion concentration]

\begin{tabular}{|c|c|c|c|c|c|c|c|c|c|}
\hline \multirow[b]{2}{*}{$\begin{array}{c}\text { Constituent } \\
(\mu \mathrm{g} / \mathrm{L})\end{array}$} & \multicolumn{2}{|c|}{ Water-quality criterion ${ }^{1}$} & \multirow[b]{2}{*}{$\begin{array}{l}\text { Number of } \\
\text { analyses }\end{array}$} & \multirow[b]{2}{*}{$\begin{array}{c}\text { Minimum } \\
(\mu \mathrm{g} / \mathrm{L})\end{array}$} & \multirow[b]{2}{*}{$\begin{array}{c}\text { Median } \\
\text { ( } \mu \mathrm{g} / \mathrm{L} \text { ) }\end{array}$} & \multirow[b]{2}{*}{$\begin{array}{l}\text { Mean } \\
(\mu \mathrm{g} / \mathrm{L})\end{array}$} & \multirow[b]{2}{*}{$\begin{array}{c}\text { Maximum } \\
(\mu \mathrm{g} / \mathrm{L})\end{array}$} & \multirow[b]{2}{*}{$\begin{array}{c}\text { Upper MAD } \\
\text { outlier limit } \\
(\mu \mathrm{g} / \mathrm{L})\end{array}$} & \multirow{2}{*}{$\begin{array}{c}\text { Percentage } \\
\text { of samples } \\
\text { above } \\
\text { detection limi }\end{array}$} \\
\hline & Basis & $\begin{array}{c}\text { Criterion } \\
\text { concentration } \\
(\mu \mathrm{g} / \mathrm{L})\end{array}$ & & & & & & & \\
\hline Aluminum, filtered & Aquatic life & $750 / 87$ & 27 & 0.01 & 10.00 & 10.44 & 38.60 & 10.00 & 48 \\
\hline Arsenic, filtered & NM DWS & 10 & 21 & 2.00 & 2.36 & 3.56 & 11.90 & 4.23 & 57 \\
\hline Chromium (VI), filtered & Aquatic life & $16 / 11$ & 4 & 0.01 & 10.00 & 10.00 & 20.00 & 35.97 & 100 \\
\hline Chromium, filtered & NM DWS & 100 & 23 & 1.00 & 1.00 & 1.14 & 2.70 & 1.00 & 22 \\
\hline Copper, filtered & Irrigation & 200 & 23 & 5.00 & 5.12 & 6.40 & 13.60 & 5.74 & 52 \\
\hline Lead, filtered & Aquatic life & $51 / 2$ & 25 & 0.01 & 2.00 & 1.51 & 2.00 & 2.00 & 28 \\
\hline Mercury, filtered & Aquatic life & $1.4 / 0.77$ & 26 & $<0.5$ & $<0.5$ & $<0.5$ & $<0.5$ & $<0.5$ & 0 \\
\hline Zinc, filtered & Irrigation & 2,000 & 17 & 0.01 & 5.00 & 7.65 & 27.30 & 5.00 & 35 \\
\hline \multicolumn{10}{|c|}{ UR-300 - San Antonio Arroyo } \\
\hline Aluminum, filtered & Aquatic life & $750 / 87$ & 24 & 3.87 & 15.60 & 93.88 & 683.00 & 55.25 & 88 \\
\hline Arsenic, filtered & NM DWS & 10 & 23 & 0.01 & 2.00 & 1.94 & 3.27 & 2.73 & 52 \\
\hline Beryllium, filtered & NM DWS & 4 & 15 & $<1$ & $<1$ & $<1$ & $<1$ & $<1$ & 0 \\
\hline Cadmium, filtered & NM DWS & 5 & 21 & 0.10 & 0.10 & 0.39 & 2.00 & 0.10 & 14 \\
\hline Chromium (VI), filtered & Aquatic life & $16 / 11$ & 5 & 0.01 & 10.00 & 6.00 & 10.00 & 10.00 & 100 \\
\hline Chromium, filtered & NM DWS & 100 & 22 & 1.00 & 1.00 & 1.31 & 3.51 & 1.00 & 32 \\
\hline Copper, filtered & Irrigation & 200 & 21 & 5.00 & 5.00 & 5.68 & 10.00 & 5.00 & 38 \\
\hline Lead, filtered & Aquatic life & $51 / 2$ & 20 & 0.01 & 2.00 & 1.76 & 6.16 & 2.00 & 40 \\
\hline Mercury, filtered & Aquatic life & $1.4 / 0.77$ & 22 & $<0.5$ & $<0.5$ & $<0.5$ & $<0.5$ & $<0.5$ & 0 \\
\hline Arsenic, filtered & NM DWS & 10 & 18 & 0.53 & 2.48 & 2.64 & 5.41 & 4.95 & 67 \\
\hline Beryllium, filtered & NM DWS & 4 & 14 & $<1$ & $<1$ & $<1$ & $<1$ & $<1$ & 0 \\
\hline Cadmium, filtered & NM DWS & 5 & 22 & 0.10 & 0.21 & 0.50 & 2.00 & 0.75 & 45 \\
\hline Chromium (VI), filtered & Aquatic life & $16 / 11$ & 6 & 0.01 & 5.01 & 8.34 & 20.00 & 30.98 & 100 \\
\hline Chromium, filtered & NM DWS & 100 & 19 & 1.00 & 1.00 & 1.51 & 3.62 & 1.00 & 32 \\
\hline Copper, filtered & Irrigation & 200 & 21 & 5.00 & 7.31 & 9.44 & 50.50 & 19.32 & 67 \\
\hline Lead, filtered & Aquatic life & $51 / 2$ & 19 & 0.01 & 2.00 & 1.76 & 2.43 & 2.00 & 37 \\
\hline Mercury, filtered & Aquatic life & $1.4 / 0.77$ & 21 & $<0.5$ & $<0.5$ & $<0.5$ & $<0.5$ & $<0.5$ & 0 \\
\hline Nickel, filtered & Aquatic life & $390 / 43$ & 20 & 5.00 & 5.00 & 5.88 & 11.10 & 5.00 & 30 \\
\hline Selenium, filtered & NM DWS & 50 & 20 & 0.01 & 2.00 & 1.26 & 2.00 & 2.00 & 40 \\
\hline Silver, filtered & Aquatic life & 2.2 (acute only) & 18 & 0.05 & 0.05 & 0.38 & 2.00 & 0.05 & 17 \\
\hline Thallium, filtered & NM DWS & 2 & 11 & $<2$ & $<2$ & $<2$ & $<2$ & $<2$ & 0 \\
\hline Zinc, filtered & Irrigation & 2,000 & 10 & 5.00 & 35.20 & 45.50 & 128.00 & 146.53 & 90 \\
\hline
\end{tabular}


Table 11. Statistical summary of concentrations for dissolved metals in urban stormwater samples from five outfalls and the Rio Grande at Albuquerque in the Albuquerque metropolitan area, New Mexico, 2003-12.-Continued

[Full site names are provided in table 1. $\mu \mathrm{g} / \mathrm{L}$, micrograms per liter; MAD, mean absolute deviation; NM DWS, New Mexico domestic water-supply standard; $<$, less than. Freshwater aquatic life criteria for metals are expressed as a function of total hardness (milligrams per liter as $\mathrm{CaCO}_{3}$ ) in the water body; values displayed correspond to a total hardness of 80 milligrams per liter as $\mathrm{CaCO}_{3}$, based on the overall median and average hardness values at the outfalls; for aquatic life concentrations, the first listed value is the acute concentration limit, and the second listed value is the chronic concentration limit; median and maximum concentrations presented in bold exceed a water-quality criterion concentration]

\begin{tabular}{|c|c|c|c|c|c|c|c|c|c|}
\hline \multirow[b]{2}{*}{$\begin{array}{c}\text { Constituent } \\
(\mu \mathrm{g} / \mathrm{L})\end{array}$} & \multicolumn{2}{|c|}{ Water-quality criterion ${ }^{1}$} & \multirow[b]{2}{*}{$\begin{array}{c}\text { Number of } \\
\text { analyses }\end{array}$} & \multirow[b]{2}{*}{$\begin{array}{c}\text { Minimum } \\
(\mu \mathrm{g} / \mathrm{L})\end{array}$} & \multirow[b]{2}{*}{$\begin{array}{c}\text { Median } \\
(\mu \mathrm{g} / \mathrm{L})\end{array}$} & \multirow[b]{2}{*}{$\begin{array}{l}\text { Mean } \\
(\mu \mathrm{g} / \mathrm{L})\end{array}$} & \multirow[b]{2}{*}{$\begin{array}{c}\text { Maximum } \\
(\mu \mathrm{g} / \mathrm{L})\end{array}$} & \multirow[b]{2}{*}{$\begin{array}{c}\text { Upper MAD } \\
\text { outlier limit } \\
(\mu \mathrm{g} / \mathrm{L})\end{array}$} & \multirow{2}{*}{$\begin{array}{c}\text { Percentage } \\
\text { of samples } \\
\text { above } \\
\text { detection limi }\end{array}$} \\
\hline & Basis & $\begin{array}{c}\text { Criterion } \\
\text { concentration } \\
(\mu \mathrm{g} / \mathrm{L})\end{array}$ & & & & & & & \\
\hline \multicolumn{10}{|c|}{ UR-500 - San Jose Drain } \\
\hline Aluminum, filtered & Aquatic life & $750 / 87$ & 26 & 0.01 & 10.00 & 17.30 & 134.00 & 10.00 & 42 \\
\hline Arsenic, filtered & NM DWS & 10 & 21 & 2.00 & 3.26 & 3.95 & 9.19 & 9.81 & 76 \\
\hline Chromium (VI), filtered & Aquatic life & $16 / 11$ & 3 & 0.01 & 10.00 & 10.00 & 20.00 & 61.95 & 100 \\
\hline Chromium, filtered & NM DWS & 100 & 23 & 1.00 & 1.00 & 1.27 & 2.13 & 1.00 & 35 \\
\hline Copper, filtered & Irrigation & 200 & 26 & 5.00 & 5.83 & 7.00 & 14.60 & 10.12 & 69 \\
\hline Lead, filtered & Aquatic life & $51 / 2$ & 23 & 0.05 & 2.00 & 1.70 & 3.79 & 2.00 & 35 \\
\hline Mercury, filtered & Aquatic life & $1.4 / 0.77$ & 26 & $<0.5$ & $<0.5$ & $<0.5$ & $<0.5$ & $<0.5$ & 0 \\
\hline Nickel, filtered & Aquatic life & $390 / 43$ & 23 & 5.00 & 5.00 & 6.34 & 30.50 & 5.00 & 17 \\
\hline Zinc, filtered & Irrigation & 2,000 & 16 & 0.01 & 17.35 & 59.77 & 652.00 & 81.57 & 81 \\
\hline \multicolumn{10}{|c|}{ UR-9900 - North Diversion Channel } \\
\hline Aluminum, filtered & Aquatic life & $750 / 87$ & 21 & 9.17 & 20.60 & 283.42 & $5,540.00$ & 54.92 & 95 \\
\hline Arsenic, filtered & NM DWS & 10 & 16 & 0.01 & 2.00 & 1.74 & 2.00 & 2.00 & 19 \\
\hline Beryllium, filtered & NM DWS & 4 & 12 & $<1$ & $<1$ & $<1$ & $<1$ & $<1$ & 0 \\
\hline Cadmium, filtered & NM DWS & 5 & 19 & 0.05 & 0.10 & 0.20 & 2.00 & 0.10 & 11 \\
\hline Chromium (VI), filtered & Aquatic life & $16 / 11$ & 4 & 0.01 & 5.01 & 5.01 & 10.00 & 30.98 & 100 \\
\hline Chromium, filtered & NM DWS & 100 & 20 & 1.00 & 1.10 & 1.98 & 12.99 & 1.62 & 50 \\
\hline Copper, filtered & Irrigation & 200 & 19 & 5.00 & 5.38 & 7.38 & 25.70 & 7.36 & 53 \\
\hline Lead, filtered & Aquatic life & $51 / 2$ & 19 & 0.16 & 2.00 & 1.80 & 6.93 & 2.00 & 37 \\
\hline Mercury, filtered & Aquatic life & $1.4 / 0.77$ & 20 & $<0.5$ & $<0.5$ & $<0.5$ & $<0.5$ & $<0.5$ & 0 \\
\hline
\end{tabular}

${ }^{1}$ New Mexico water-quality standards (NM WQSs) as described in State of New Mexico Standards for Interstate and Intrastate Surface Waters (20.6.4 New Mexico Administrative Code).

Dissolved beryllium, dissolved mercury, and dissolved thallium were not detected in any of the outfall stormwater samples. The highest dissolved metal concentrations generally were detected at the Barelas Pump Station, San Jose Drain, and North Diversion Channel outfalls (table 11). These outfalls drain basins that have more urban development as compared to the San Antonio Arroyo and South Diversion Channel outfalls, which drain basins with less urban development and where the lowest concentrations for dissolved metals generally occurred.

\section{Organic Compounds}

The organic compounds were grouped into five categories: (1) VOCs; (2) SVOCs; (3) 16 polycyclic aromatic hydrocarbons (PAH16), listed as priority pollutants by the EPA (U.S. Environmental Protection Agency, 2014a); (4) pesticides; and (5) PCBs. Many of the organic compounds analyzed in this study have NM WQSs that are based on designated water use criteria for either domestic water supply or HH-OO. Of the nearly 200 organic compounds that were analyzed in this study, less than onethird (58 constituents) of the constituents were detected at or above the analytical detection limit at any of the outfalls (tables 12-15). The nondetected organic constituents analyzed for in the stormwater samples from the five outfalls are listed in table 16. 
Table 12. Statistical summary of concentrations for detected volatile organic compounds in urban stormwater samples from five outfalls in the Albuquerque metropolitan area, New Mexico, 2003-12.

[Full site names are provided in table 1. NM DWS, New Mexico domestic water-supply standard; $\mu \mathrm{g} / \mathrm{L}$, micrograms per liter; MAD, mean absolute deviation; - , no value; median and maximum concentrations presented in bold exceed a water-quality criterion concentration]

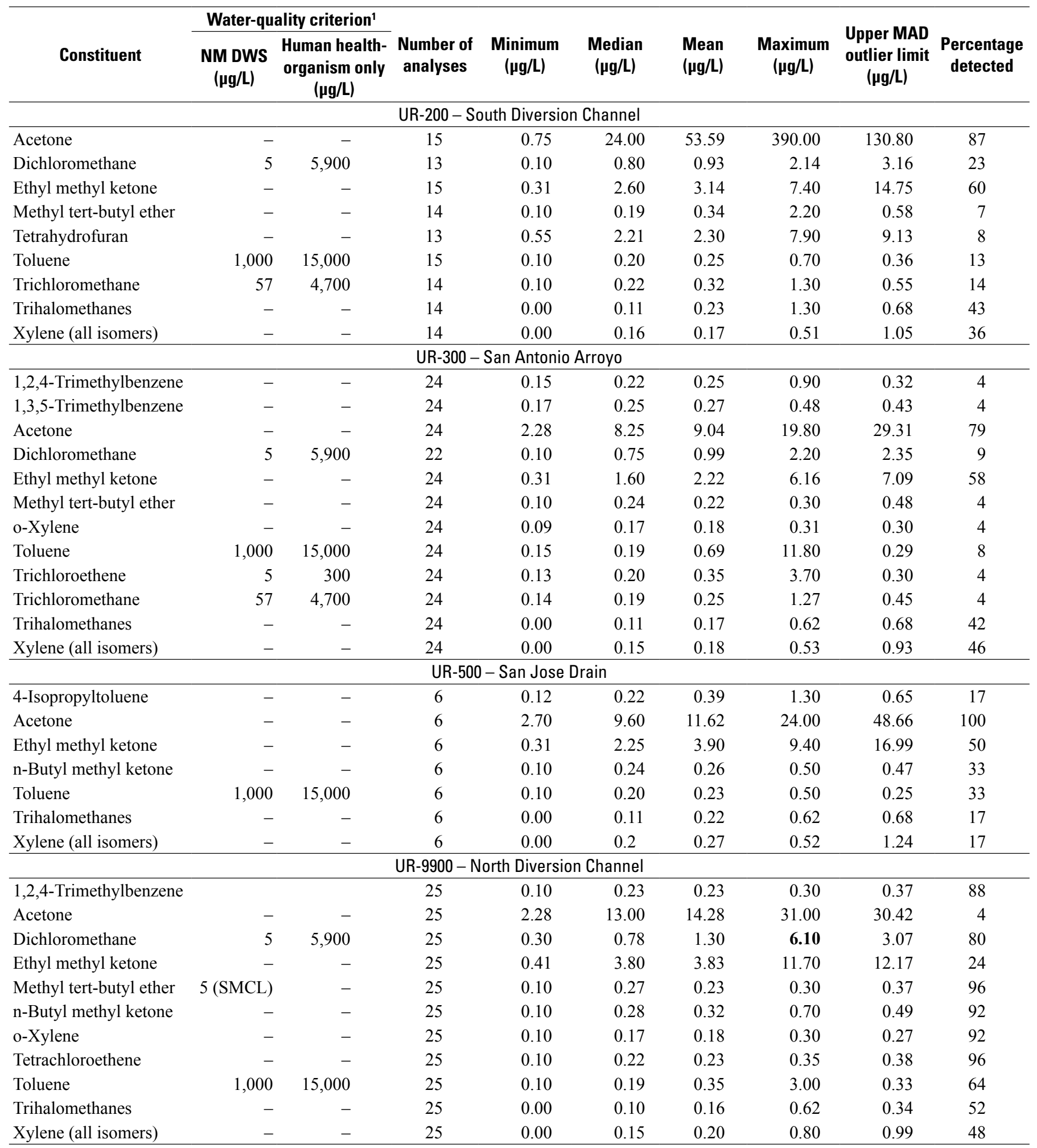

${ }^{1}$ New Mexico water-quality standards (NM WQSs) as described in State of New Mexico Standards for Interstate and Intrastate Surface Waters (20.6.4 New Mexico Administrative Code). 
Table 13. Statistical summary of concentrations for detected semivolatile organic compounds in urban stormwater samples from five outfalls in the Albuquerque metropolitan area, New Mexico, 2003-12.

[Full site names are provided in table 1. NM DWS, New Mexico domestic water-supply standard; $\mu \mathrm{g} / \mathrm{L}$, micrograms per liter; MAD, mean absolute deviation; -, no value; median and maximum concentrations presented in bold exceed a water-quality criterion concentration]

\begin{tabular}{|c|c|c|c|c|c|c|c|c|c|}
\hline \multirow[b]{2}{*}{ Constituent } & \multicolumn{2}{|c|}{ Water-quality criterion $^{1}$} & \multirow[b]{2}{*}{$\begin{array}{l}\text { Number of } \\
\text { analyses }\end{array}$} & \multirow[b]{2}{*}{$\begin{array}{c}\text { Minimum } \\
(\mu \mathrm{g} / \mathrm{L})\end{array}$} & \multirow[b]{2}{*}{$\begin{array}{c}\text { Median } \\
(\mu \mathrm{g} / \mathrm{L})\end{array}$} & \multirow[b]{2}{*}{$\begin{array}{l}\text { Mean } \\
(\mu \mathrm{g} / \mathrm{L})\end{array}$} & \multirow[b]{2}{*}{$\begin{array}{c}\text { Maximum } \\
(\mu \mathrm{g} / \mathrm{L})\end{array}$} & \multirow[b]{2}{*}{$\begin{array}{c}\text { Upper MAD } \\
\text { outlier limit } \\
(\mu \mathrm{g} / \mathrm{L})\end{array}$} & \multirow[b]{2}{*}{$\begin{array}{c}\text { Percentage } \\
\text { detected }\end{array}$} \\
\hline & $\begin{array}{c}\text { NM DWS } \\
(\mu \mathrm{g} / \mathrm{L})\end{array}$ & $\begin{array}{c}\text { Human health- } \\
\text { organism only } \\
(\mu \mathrm{g} / \mathrm{L})\end{array}$ & & & & & & & \\
\hline \multicolumn{10}{|c|}{ UR-200 - South Diversion Channel } \\
\hline Aniline & - & - & 19 & 0.05 & 0.10 & 0.13 & 0.28 & 0.31 & 5 \\
\hline Benzoic acid & - & - & 8 & 0.32 & 0.33 & 4.60 & 27.30 & 0.35 & 25 \\
\hline Benzyl n-butyl phthalate & 7,000 & 1,900 & 26 & 0.08 & 0.31 & 0.43 & 1.20 & 0.95 & 50 \\
\hline Bis(2-ethylhexyl) adipate & - & - & 18 & 0.07 & 0.21 & 0.46 & 1.80 & 0.91 & 22 \\
\hline Bis(2-ethylhexyl) phthalate & 6 & 22 & 29 & 0.60 & 2.00 & 2.97 & 15.20 & 5.54 & 97 \\
\hline Carbazole & - & - & 29 & 0.05 & 0.13 & 0.21 & 0.70 & 0.29 & 17 \\
\hline Diethyl phthalate & 28,000 & 44,000 & 25 & 0.03 & 0.80 & 3.74 & 33.00 & 3.40 & 76 \\
\hline Phenol & 10,500 & 860,000 & 26 & 0.05 & 0.14 & 0.21 & 0.67 & 0.38 & 4 \\
\hline Phenolic compounds & - & - & 28 & 10.00 & 75.00 & 82.07 & 331.00 & 205.00 & 18 \\
\hline \multicolumn{10}{|c|}{ UR-300 - San Antonio Arroyo } \\
\hline Benzoic acid & - & - & 6 & 0.31 & 0.32 & 2.11 & 9.20 & 0.35 & 33 \\
\hline Benzyl alcohol & - & - & 25 & 0.07 & 0.31 & 0.45 & 2.30 & 1.28 & 52 \\
\hline Benzyl n-butyl phthalate & 7,000 & 1,900 & 24 & 0.08 & 0.30 & 0.50 & 2.20 & 0.82 & 50 \\
\hline Bis(2-ethylhexyl) adipate & - & - & 18 & 0.07 & 0.21 & 0.46 & 1.80 & 0.94 & 39 \\
\hline Bis(2-ethylhexyl) phthalate & 6 & 22 & 25 & 0.80 & 2.10 & 2.32 & 9.00 & 5.22 & 100 \\
\hline Carbazole & - & - & 25 & 0.05 & 0.13 & 0.15 & 0.53 & 0.44 & 8 \\
\hline Diethyl phthalate & 28,000 & 44,000 & 21 & 0.03 & 0.20 & 0.30 & 1.10 & 0.82 & 57 \\
\hline 2-Methylnaphthalene & - & - & 24 & 0.06 & 0.17 & 0.22 & 0.50 & 0.61 & 4 \\
\hline Aniline & - & - & 15 & 0.05 & 0.14 & 0.16 & 0.30 & 0.34 & 7 \\
\hline Benzidine & 0.0015 & 0.0020 & 15 & 0.15 & 0.86 & 1.12 & 3.70 & 4.08 & 13 \\
\hline Benzoic acid & - & - & 9 & 0.31 & 3.80 & 3.46 & 9.20 & 10.04 & 44 \\
\hline Benzyl alcohol & - & - & 24 & 0.07 & 0.40 & 0.60 & 1.90 & 1.67 & 50 \\
\hline Benzyl n-butyl phthalate & 7,000 & 1,900 & 21 & 0.20 & 1.00 & 1.62 & 11.00 & 3.60 & 90 \\
\hline Bis(2-ethylhexyl) adipate & - & - & 15 & 0.07 & 0.48 & 0.79 & 3.50 & 2.61 & 40 \\
\hline Bis(2-ethylhexyl) phthalate & 6 & 22 & 24 & 0.13 & 5.55 & 7.95 & 25.80 & 18.03 & 96 \\
\hline Carbazole & - & - & 24 & 0.05 & 0.13 & 0.27 & 1.10 & 0.45 & 8 \\
\hline Diethyl phthalate & 28,000 & 44,000 & 24 & 0.03 & 0.55 & 0.64 & 2.50 & 1.80 & 79 \\
\hline Dimethyl phthalate & 350,000 & $1,100,000$ & 24 & 0.05 & 0.20 & 0.21 & 0.80 & 0.60 & 33 \\
\hline Di-n-butyl phthalate & 3,500 & 4,500 & 24 & 0.12 & 0.45 & 0.54 & 2.40 & 1.59 & 71 \\
\hline Di-n-octyl phthalate & - & - & 24 & 0.16 & 0.79 & 1.30 & 6.10 & 3.67 & 38 \\
\hline Phenol & 10,500 & 860,000 & 23 & 0.05 & 0.15 & 0.26 & 0.67 & 0.46 & 4 \\
\hline Phenolic compounds & - & - & 22 & 50.00 & 100.00 & 87.36 & 171.00 & 100.00 & 9 \\
\hline
\end{tabular}


Table 13. Statistical summary of concentrations for detected semivolatile organic compounds in urban stormwater samples from five outfalls in the Albuquerque metropolitan area, New Mexico, 2003-12.-Continued

[Full site names are provided in table 1. NM DWS, New Mexico domestic water-supply standard; $\mu \mathrm{g} / \mathrm{L}$, micrograms per liter; MAD, mean absolute deviation; -, no value; median and maximum concentrations presented in bold exceed a water-quality criterion concentration]

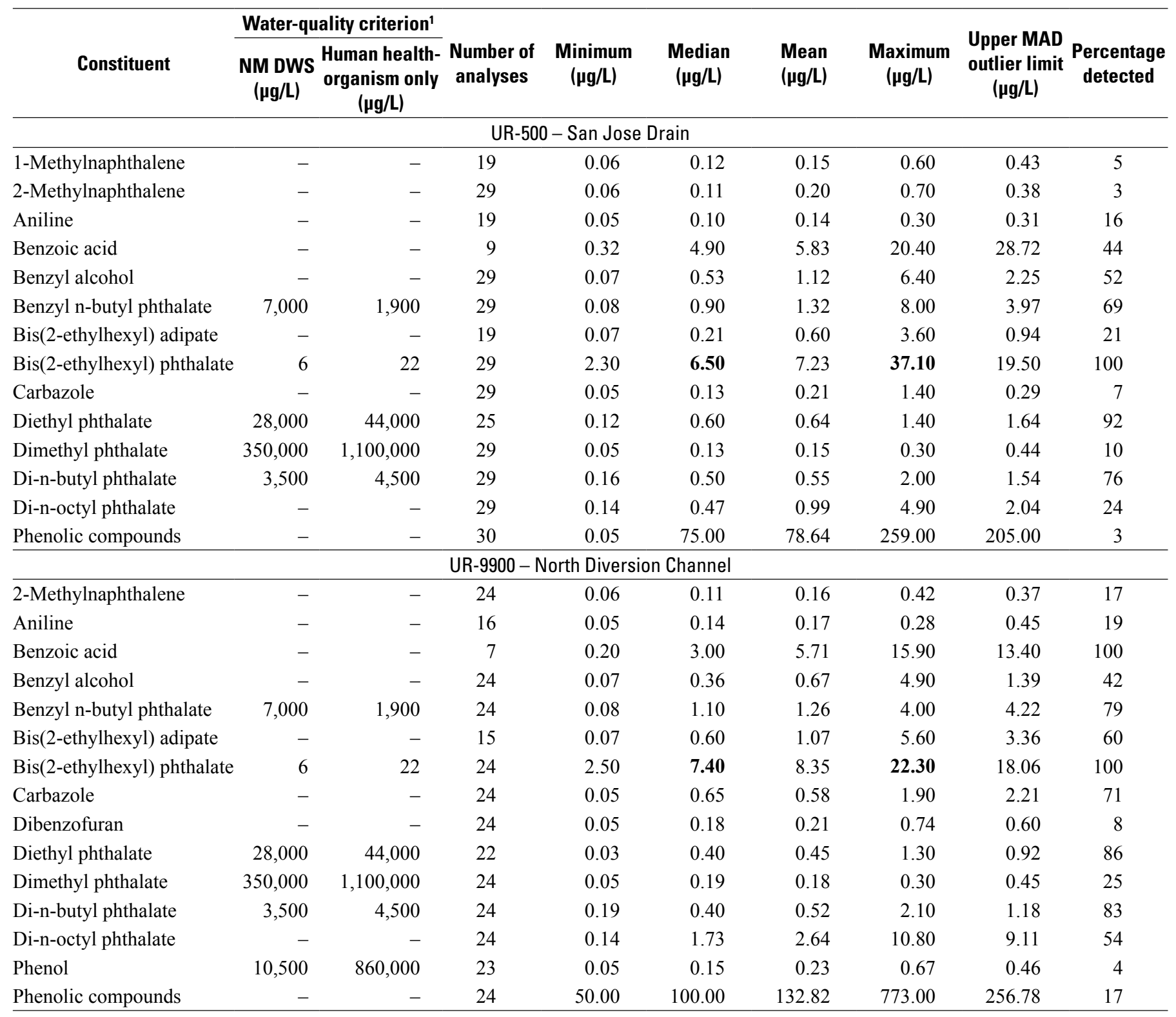

${ }^{1}$ New Mexico water-quality standards (NM WQSs) as described in State of New Mexico Standards for Interstate and Intrastate Surface Waters (20.6.4 New Mexico Administrative Code). 
Table 14. Statistical summary of concentrations for detected polycyclic aromatic hydrocarbons in urban stormwater samples from five outfalls in the Albuquerque metropolitan area, New Mexico, 2003-12.

[Full site names are provided in table 1. NM DWS, New Mexico domestic water-supply standard; $\mu \mathrm{g} / \mathrm{L}$, micrograms per liter; MAD, mean absolute deviation value; -, no value; median and maximum concentrations presented in bold exceed a water-quality criterion concentration]

\begin{tabular}{|c|c|c|c|c|c|c|c|c|c|}
\hline \multirow[b]{2}{*}{ Constituent } & \multicolumn{2}{|c|}{ Water-quality criterion' } & \multirow[b]{2}{*}{$\begin{array}{c}\text { Number of } \\
\text { analyses }\end{array}$} & \multirow[b]{2}{*}{$\begin{array}{c}\text { Minimum } \\
(\mu \mathrm{g} / \mathrm{L})\end{array}$} & \multirow[b]{2}{*}{$\begin{array}{c}\text { Median } \\
(\mu \mathrm{g} / \mathrm{L})\end{array}$} & \multirow[b]{2}{*}{$\begin{array}{l}\text { Mean } \\
(\mu \mathrm{g} / \mathrm{L})\end{array}$} & \multirow[b]{2}{*}{$\begin{array}{c}\text { Maximum } \\
(\mu \mathrm{g} / \mathrm{L})\end{array}$} & \multirow[b]{2}{*}{$\begin{array}{c}\text { Upper MAD } \\
\text { outlier limit } \\
\qquad(\mu \mathrm{g} / \mathrm{L})\end{array}$} & \multirow[b]{2}{*}{$\begin{array}{c}\text { Percentage } \\
\text { detected }\end{array}$} \\
\hline & $\begin{array}{c}\text { NM DWS } \\
(\mu \mathrm{g} / \mathrm{L})\end{array}$ & $\begin{array}{c}\text { Human } \\
\text { health- } \\
\text { organism only } \\
(\mu \mathrm{g} / \mathrm{L})\end{array}$ & & & & & & & \\
\hline \multicolumn{10}{|c|}{ UR-200 - South Diversion Channel } \\
\hline Anthracene & 10,500 & 40,000 & 29 & 0.05 & 0.21 & 0.299 & 1 & 0.678 & 7 \\
\hline Benzo[b]fluoranthene & 0.0480 & 0.1800 & 29 & 0.093 & 0.5 & 0.817 & 2.4 & 1.696 & 41 \\
\hline Benzo[ghi]perylene & - & - & 29 & 0.2 & 0.37 & 0.431 & 1.2 & 0.76 & 7 \\
\hline Benzo[k]fluoranthene & 0.0480 & 0.1800 & 29 & 0.1 & 0.78 & 0.708 & 1.3 & 1.3572 & 7 \\
\hline Chrysene & 0.0480 & 0.1800 & 29 & 0.123 & 0.36 & 0.619 & 1.8 & 1.4 & 38 \\
\hline Fluoranthene & 1,400 & 140 & 29 & 0.05 & 0.4 & 0.865 & 3.1 & 2.064 & 69 \\
\hline \multicolumn{10}{|c|}{ UR-300 - San Antonio Arroyo } \\
\hline Benzo[b]fluoranthene & 0.0480 & 0.1800 & 25 & 0.093 & 0.3 & 0.74 & 2.18 & 1.376 & 4 \\
\hline Chrysene & 0.0480 & 0.1800 & 25 & 0.136 & 0.36 & 0.43 & 1.7 & 0.776 & 4 \\
\hline Fluoranthene & 1,400 & 140 & 25 & 0.05 & 0.121 & 0.24 & 2.4 & 0.334 & 12 \\
\hline Phenanthrene & - & - & 25 & 0.07 & 0.115 & 0.23 & 0.8 & 0.349 & 4 \\
\hline Pyrene & 1,050 & 4,000 & 25 & 0.05 & 0.094 & 0.18 & 1.4 & 0.323 & 4 \\
\hline \multicolumn{10}{|c|}{ UR-400B - Barelas Pump Station } \\
\hline 9H-Fluorene & 1,400 & 5,300 & 24 & 0.056 & 0.11 & 0.221 & 1.4 & 0.37 & 4 \\
\hline Anthracene & 10,500 & 40,000 & 24 & 0.05 & 0.225 & 0.281 & 0.79 & 0.875 & 4 \\
\hline Fluoranthene & 1,400 & 140 & 24 & 0.097 & 0.85 & 1.828 & 10 & 4.386 & 63 \\
\hline Indeno[1,2,3-cd]pyrene & 0.0480 & 0.1800 & 24 & 0.19 & 0.4045 & 0.774 & 4.4 & 1.0259 & 17 \\
\hline Naphthalene & - & - & 24 & 0.09 & 0.1075 & 0.179 & 0.35 & 0.1985 & 8 \\
\hline Phenanthrene & - & - & 23 & 0.08 & 0.3 & 0.683 & 4 & 1.288 & 39 \\
\hline Pyrene & 1,050 & 4,000 & 24 & 0.077 & 0.51 & 1.193 & 5.8 & 2.668 & 58 \\
\hline \multicolumn{10}{|c|}{ UR-500 - San Jose Drain } \\
\hline Benzo[a]pyrene & 0.20 & 0.18 & 29 & 0.145 & 0.36 & 0.555 & 1.65 & 1.244 & 7 \\
\hline Benzo[b]fluoranthene & 0.0480 & 0.1800 & 29 & 0.093 & 0.3 & 0.826 & 3.4 & 1.3764 & 10 \\
\hline Benzo[ghi]perylene & - & - & 29 & 0.2 & 0.37 & 0.407 & 0.97 & 0.786 & 3 \\
\hline Chrysene & 0.0480 & 0.1800 & 29 & 0.123 & 0.34 & 0.447 & 1.7 & 1.276 & 3 \\
\hline Fluoranthene & 1,400 & 140 & 29 & 0.05 & 0.32 & 0.624 & 2.1 & 1.568 & 52 \\
\hline Naphthalene & - & 8.960 & 29 & 0.08 & 0.11 & 0.157 & 0.35 & 0.2264 & 10 \\
\hline Phenanthrene & - & - & 29 & 0.07 & 0.3 & 0.382 & 0.8 & 1.262 & 38 \\
\hline Pyrene & 1,050 & 4,000 & 28 & 0.05 & 0.21 & 0.424 & 1.8 & 0.938 & 39 \\
\hline
\end{tabular}




\section{Summary of Urban Stormwater Quality in Albuquerque, New Mexico, 2003-12}

Table 14. Statistical summary of concentrations for detected polycyclic aromatic hydrocarbons in urban stormwater samples from five outfalls in the Albuquerque metropolitan area, New Mexico, 2003-12.-Continued

[Full site names are provided in table 1. NM DWS, New Mexico domestic water-supply standard; $\mu \mathrm{g} / \mathrm{L}$, micrograms per liter; MAD, mean absolute deviation value; -, no value; median and maximum concentrations presented in bold exceed a water-quality criterion concentration]

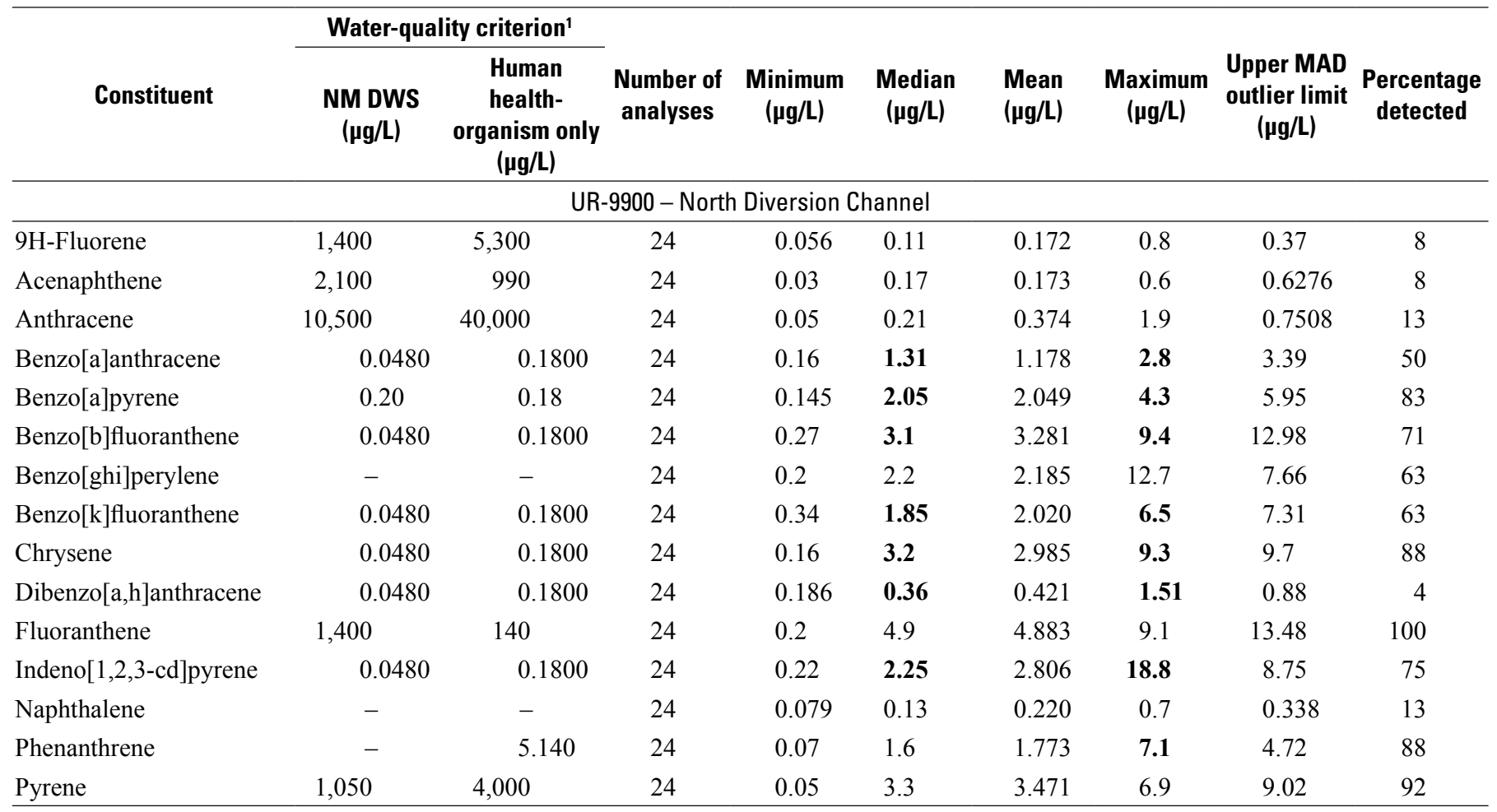

${ }^{1}$ New Mexico water-quality standards (NM WQSs) as described in State of New Mexico Standards for Interstate and Intrastate Surface Waters (20.6.4 New Mexico Administrative Code). 
Table 15. Statistical summary of concentrations for detected pesticides in urban stormwater samples from five outfalls in the Albuquerque metropolitan area, New Mexico, 2003-12.

[Full site names are provided in table 1. NM DWS, New Mexico domestic water-supply standard; $\mu \mathrm{g} / \mathrm{L}$, micrograms per liter; MAD, mean absolute deviation; - , no value; median and maximum concentrations presented in bold exceed a water-quality criterion concentration]

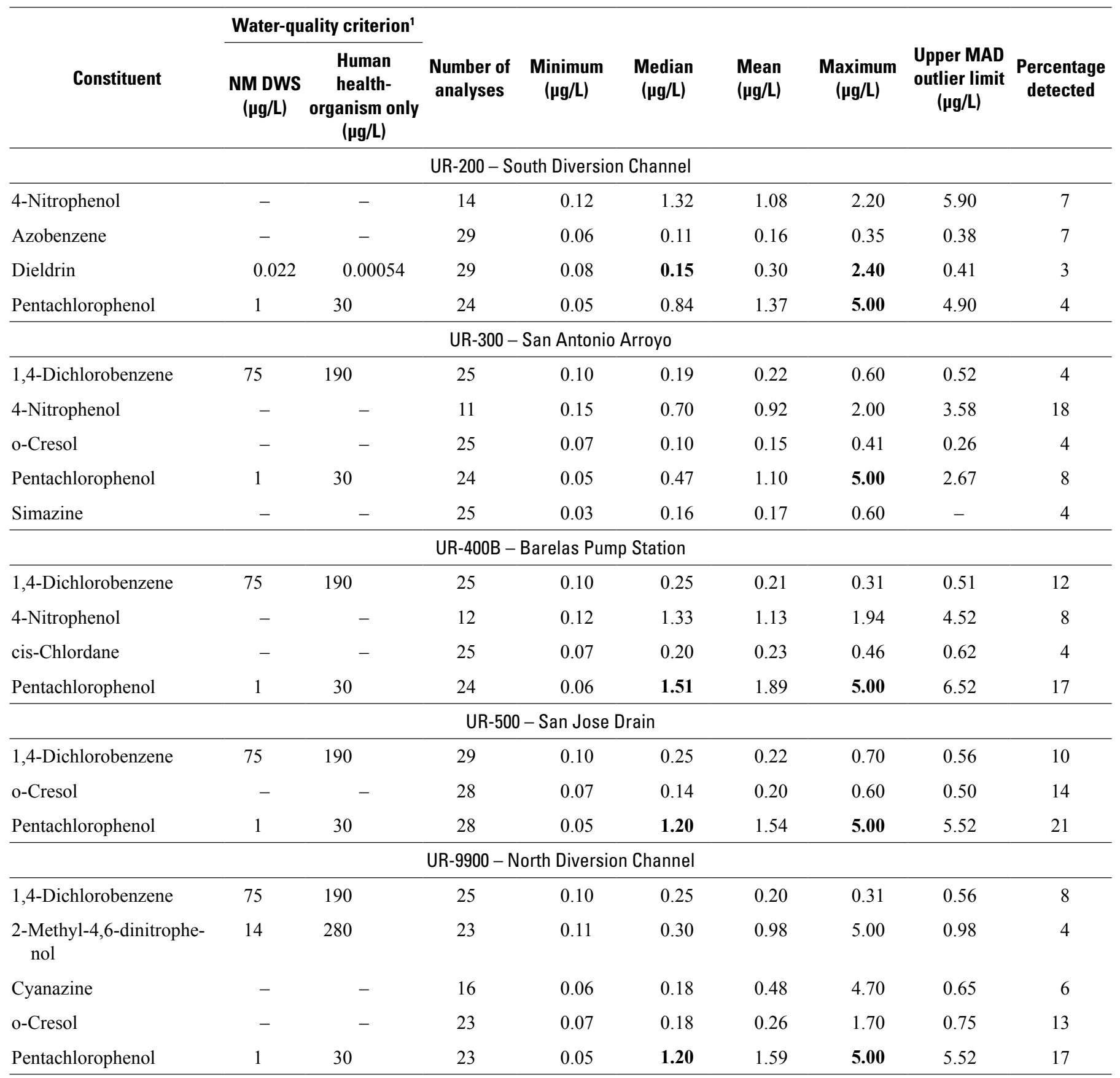

${ }^{1}$ New Mexico water-quality standards (NM WQSs) as described in State of New Mexico Standards for Interstate and Intrastate Surface Waters (20.6.4 New Mexico Administrative Code). 


\section{Summary of Urban Stormwater Quality in Albuquerque, New Mexico, 2003-12}

Table 16. Organic constituents not detected in urban stormwater samples from five outfalls in the Albuquerque metropolitan area, New Mexico, 2003-12.

\begin{tabular}{|c|c|c|c|}
\hline Oil and grease & 4-Chloro-3-methylphenol & $\mathrm{p}, \mathrm{p}^{\prime}-\mathrm{DDE}$ & 1,1-Dichloropropene \\
\hline 2-Nitroaniline & Trichlorofluoromethane & Aldrin & 2,2-Dichloropropane \\
\hline 4-Nitroaniline & 1,1-Dichloroethane & alpha-HCH & 1,3-Dichloropropane \\
\hline Dibromomethane & 1,1-Dichloroethene & beta-HCH & Isopropylbenzene \\
\hline 4-Chloroaniline & 1,1,1-Trichloroethane & Lindane & n-Propylbenzene \\
\hline Bromodichloromethane & 1,1,2-Trichloroethane & Metolachlor & 4-Chlorotoluene \\
\hline Tetrachloromethane & 1,1,2,2-Tetrachloroethane & Endrin & Bromochloromethane \\
\hline 1,2-Dichloroethane & 1,2-Dichlorobenzene & Heptachlor & n-Butylbenzene \\
\hline Tribromomethane & 1,2-Dichloropropane & Heptachlor epoxide & sec-Butylbenzene \\
\hline Dibromochloromethane & trans-1,2-Dichloroethene & p,p'-Methoxychlor & tert-Butylbenzene \\
\hline Benzene & 1,2,4-Trichlorobenzene & Aroclor 1221 & 1,2,3-Trichloropropane \\
\hline Acrolein & 1,3-Dichlorobenzene & Aroclor 1232 & 1,1,1,2-Tetrachloroethane \\
\hline Acrylonitrile & 2-Chloroethyl vinyl ether & Aroclor 1248 & 1,2,3-Trichlorobenzene \\
\hline delta-HCH & 2-Chloronaphthalene & Aroclor 1254 & 1,2-Dibromoethane \\
\hline Bis(2-chloroethyl) ether & 2-Chlorophenol & Aroclor 1260 & 2,4,5-Trichlorophenol \\
\hline Bis(2-chloroethoxy)methane & 2-Nitrophenol & Atrazine & 2,3,4,6-Tetrachlorophenol \\
\hline Bis(2-chloroisopropyl) & 2,4-Dichlorophenol & Hexachlorobenzene & Endrin ketone \\
\hline Chlorobenzene & 2,4-Dimethylphenol & Hexachlorobutadiene & 3-Chloropropene \\
\hline Chloroethane & 2,4-Dinitrotoluene & 1,3-Dinitrobenzene & 3-Nitroaniline \\
\hline Endosulfan sulfate & 2,4-Dinitrophenol & Iodomethane & Chloroprene \\
\hline beta-Endosulfan & 2,4,6-Trichlorophenol & trans-1,4-Dichloro-2-butene & Metribuzin \\
\hline alpha-Endosulfan & 2,6-Dinitrotoluene & cis-1,4-Dichloro-2-butene & Pentachloroethane \\
\hline Endrin aldehyde & 3,3'-Dichlorobenzidine & Alachlor & Bromobenzene \\
\hline Ethylbenzene & 4-Bromophenyl phenyl ether & Ethyl methacrylate & 1,4-Dioxane \\
\hline Hexachlorocyclopentadiene & 4-Chlorophenyl phenyl ether & Acetonitrile & Methyl acrylonitrile \\
\hline Hexachloroethane & Dichlorodifluoromethane & Propionitrile & Methyl methacrylate \\
\hline Isophorone & trans-1,3-Dichloropropene & Isobutyl alcohol & Aroclor 1016 plus Aroclor 1242 \\
\hline Bromomethane & cis-1,3-Dichloropropene & Carbon disulfide & 1-Methylnaphthalene \\
\hline Chloromethane & Prometryn & Pyridine & 1,2-Dibromo-3-chloropropane \\
\hline N-Nitrosodi-n-propylamine & trans-Chlordane & Vinyl acetate & 1,2-Dinitrobezene \\
\hline N-Nitrosodiphenylamine & Benzidine & Vinyl chloride & 1,4-Dinitrobezene \\
\hline N-Nitrosodimethylamine & $\mathrm{p}, \mathrm{p}^{\prime}-\mathrm{DDT}$ & cis-1,2-Dichloroethene & \\
\hline Nitrobenzene & p,p'-DDD & Styrene & \\
\hline
\end{tabular}




\section{Volatile Organic Compounds}

The most frequently detected VOCs in stormwater samples from the outfalls were acetone, ethyl methyl ketone, trihalomethanes, and xylene. Although acetone is a common laboratory contaminant (U.S. Environmental Protection Agency, 2014b), acetone was not detected at levels above the minimum reporting limit in any of the field or laboratory blanks. The acetone detected in the stormwater samples, therefore, is likely from the environment. The median concentrations for ethyl methyl ketone, trihalomethanes, and xylene (figs. 9-11) were similar for each outfall (table 12). Maximum concentrations for VOCs did not exceed any NM WQS (except for dichloromethane at one site).

A total of 9 VOCs were detected in stormwater samples from the South Diversion Channel outfall, with 7 of those 9 VOCs detected in more than 10 percent of the stormwater samples. Acetone, ethyl methyl ketone, and trihalomethanes had the greatest numbers of detections at this site; these VOCs do not have associated water-quality standards. Maximum concentrations for the remaining VOCs did not exceed NM WQSs for domestic water supply (table 12).

A total of 12 VOCs were detected in stormwater samples from the San Antonio Arroyo outfall, with 4 of the 12 VOCs detected in more than 10 percent of the stormwater samples. Acetone, ethyl methyl ketone, and xylene had the greatest numbers of detections at this site (table 12). Maximum concentrations for the remaining VOCs did not exceed NM WQSs for domestic water supply.

No VOC stormwater samples were collected at the Barelas Pump Station outfall because the aeration of stormwater from pumping that occurs there would likely volatize all VOCs prior to sampling.

A total of 7 VOCs were detected in stormwater samples from the San Jose Drain outfall, with all 7 of these VOCs detected in more than 10 percent of the stormwater samples. Acetone and ethyl methyl ketone had the greatest numbers of detections at this site (table 12). Maximum concentrations for the remaining VOCs did not exceed NM WQSs for domestic water supply.

A total of 11 VOCs were detected in stormwater samples from the North Diversion Channel outfall, with 7 of the 11 VOCs detected in more than 10 percent of the stormwater samples. Acetone, ethyl methyl ketone, and xylene had the greatest numbers of detections at this site. Dichloromethane was the only VOC with a maximum concentration exceeding the NM WQS of $5 \mu \mathrm{g} / \mathrm{L}$ for domestic water supply (table 12).

No clear relation exists between the degree of urban development and the presence of VOCs in surface water within a basin. The number of VOCs detected at any one outfall appears to be a function of the number of stormwater samples collected at that outfall. The basin drained by the San Antonio Arroyo outfall had the least urban development but had the greatest number of VOC detections in the stormwater samples, and San Antonio Arroyo was one of the most often sampled outfalls. The San Jose Drain outfall had the fewest
VOC detections and was sampled the least, yet this outfall drains a basin with greater urban development.

\section{Semivolatile Organic Compounds}

The most frequently detected SVOCs in stormwater samples from the outfalls were bis(2-ethylhexyl) phthalate, di-n-butyl phthalate, and diethyl phthalate (table 13). In the stormwater samples, median concentrations for bis(2ethylhexyl) phthalate ranged from $2.00 \mu \mathrm{g} / \mathrm{L}$ at the South Diversion Channel outfall to $7.40 \mu \mathrm{g} / \mathrm{L}$ at the North Diversion Channel outfall (fig. 12); di-n-butyl phthalate ranged from $0.20 \mu \mathrm{g} / \mathrm{L}$ at the San Antonio Arroyo outfall to $0.50 \mu \mathrm{g} / \mathrm{L}$ at the San Jose Drain outfall (fig. 13); and diethyl phthalate ranged from $0.20 \mu \mathrm{g} / \mathrm{L}$ at the San Antonio Arroyo outfall to $0.80 \mu \mathrm{g} / \mathrm{L}$ at the South Diversion Channel outfall (fig. 14). Maximum concentrations for SVOCs did not exceed any water-quality criteria (except for benzidine at one site).

A total of 13 SVOCs were detected in stormwater samples from the South Diversion Channel outfall, with 11 SVOCs detected in more than 10 percent of the stormwater samples. Bis(2-ethylhexyl) phthalate, di-n-butyl phthalate, and diethyl phthalate had the greatest numbers of detections at this site. No maximum concentrations for SVOCs exceeded any waterquality criteria (table 13).

A total of 12 SVOCs were detected in stormwater samples from the San Antonio Arroyo outfall, with 8 SVOCs detected in more than 10 percent of the stormwater samples. Bis(2-ethylhexyl) phthalate, di-n-butyl phthalate, and diethyl phthalate had the greatest numbers of detections at this site. No maximum concentrations for SVOCs exceeded any waterquality criteria (table 13).

A total of 15 SVOCs were detected in stormwater samples from the Barelas Pump Station outfall, with 10 SVOCs detected in more than 10 percent of the stormwater samples. Bis(2-ethylhexyl) phthalate and benzyl n-butyl phthalate (each detected in more than 90 percent of the samples), diethyl phthalate, and di-n-butyl phthalate had the greatest numbers of detections at this site. Benzidine was the only SVOC that had a maximum concentration exceeding the NM WQS (table 13).

A total of 14 SVOCs were detected in stormwater samples from the San Jose Drain outfall, with 9 SVOCs detected in more than 10 percent of the stormwater samples. Bis(2-ethylhexyl) phthalate, diethyl phthalate, and di-n-butyl phthalate had the greatest numbers of detections at this site. No maximum concentrations for SVOCs exceeded any waterquality criteria (table 13).

A total of 15 SVOCs were detected in stormwater samples from the North Diversion Channel outfall, with all detected SVOCs, except for dibenzofuran and phenol, detected in more than 10 percent of the stormwater samples. Bis(2-ethylhexyl) phthalate, benzoic acid, diethyl phthalate, and di-n-butyl phthalate had the greatest numbers of detections at this site but did not have maximum concentrations that exceeded any NM WQS (benzoic acid does not have an NM WQS associated with it). 


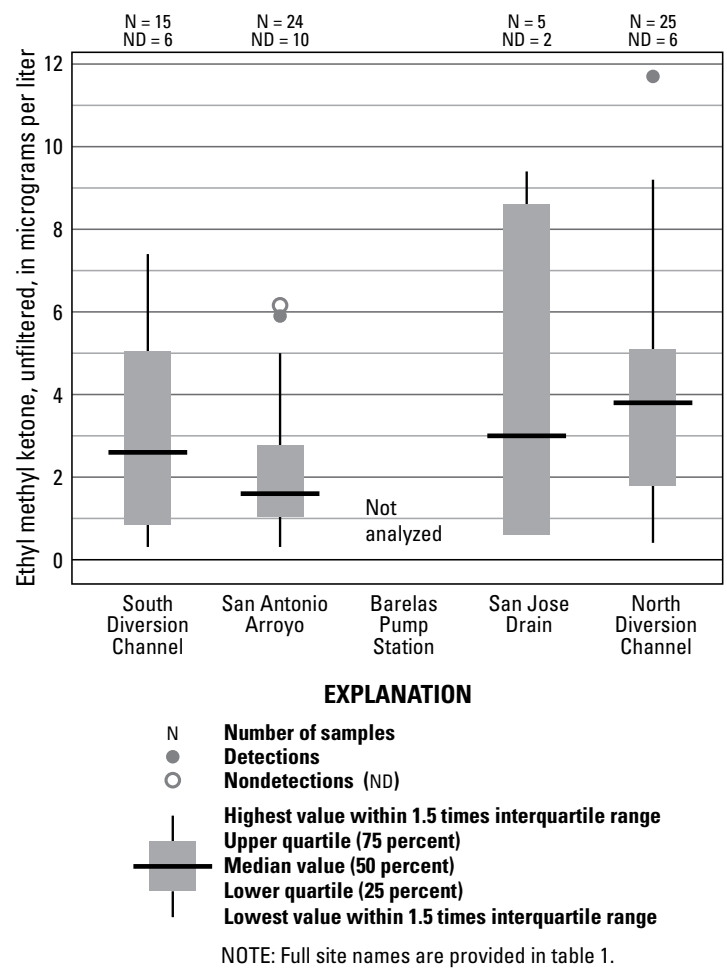

Figure 9. Ethyl methyl ketone concentrations in urban stormwater samples from five outfalls in the Albuquerque metropolitan area, New Mexico, 2003-12.

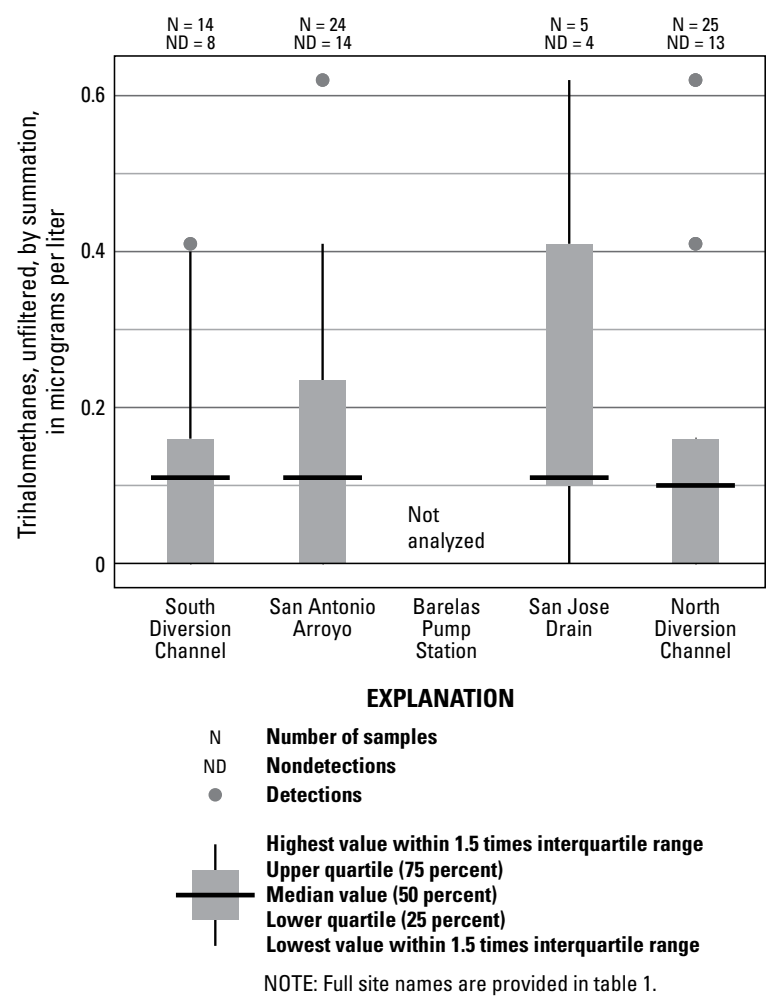

Figure 10. Trihalomethane concentrations in urban stormwater samples from five outfalls in the Albuquerque metropolitan area, New Mexico, 2003-12.

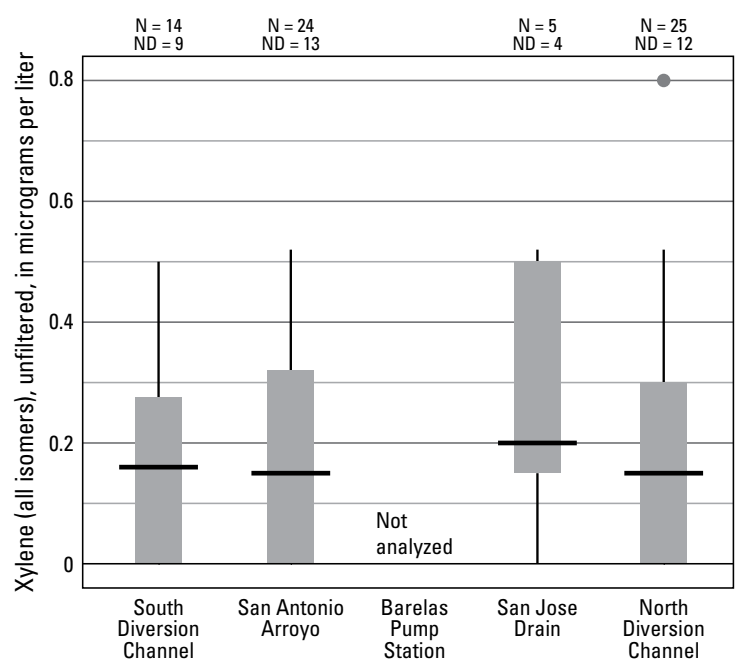

EXPLANATION

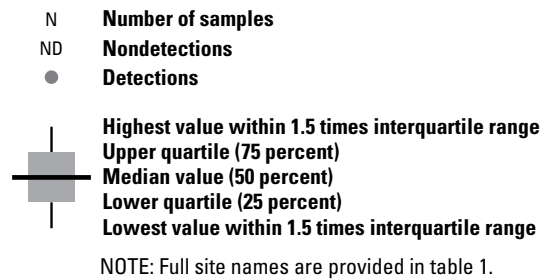

Figure 11. Xylene concentrations in urban stormwater samples from five outfalls in the Albuquerque metropolitan area, New Mexico, 2003-12.

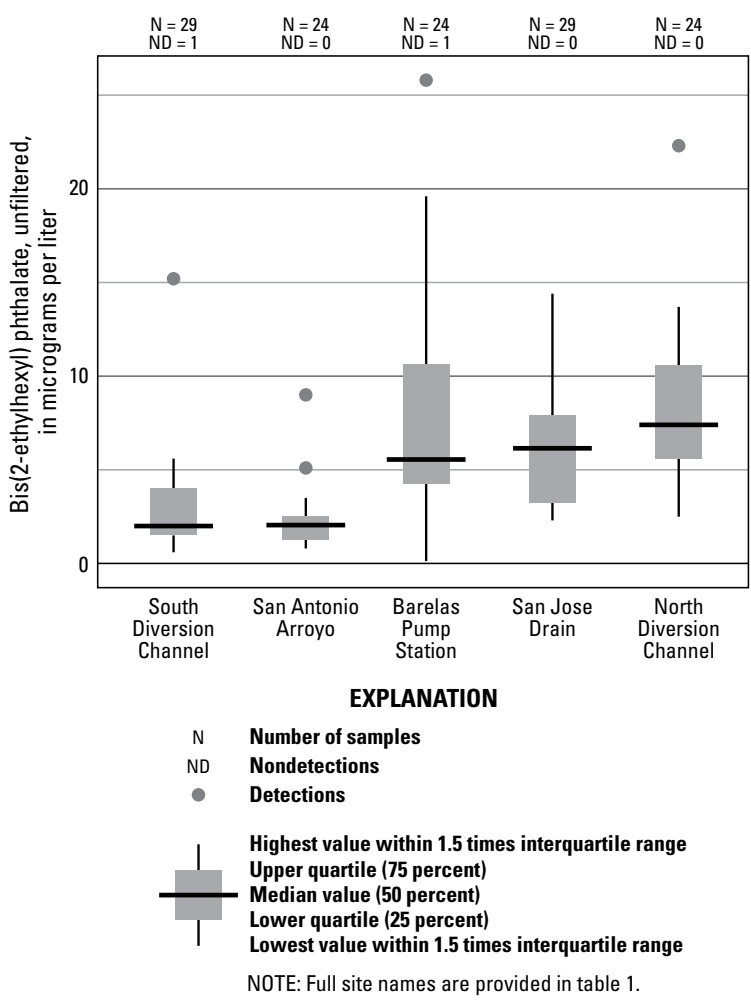

Figure 12. Bis(2-ethylhexyl) phthalate concentrations in urban stormwater samples from five outfalls in the Albuquerque metropolitan area, New Mexico, 2003-12. 


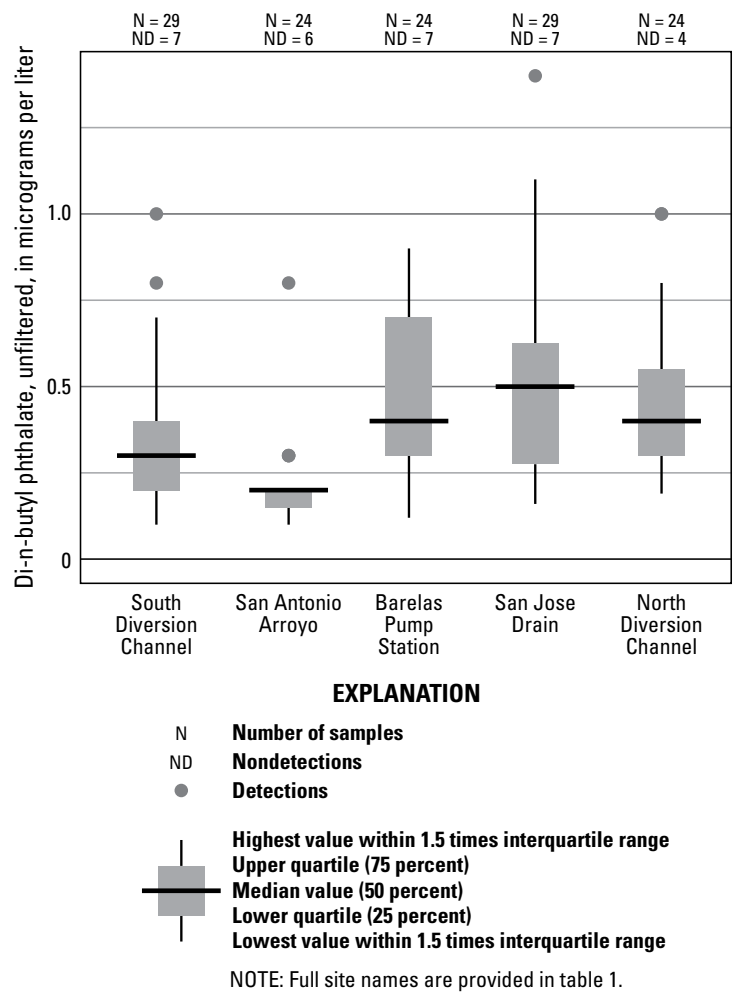

Figure 13. Di-n-butyl phthalate concentrations in urban stormwater samples from five outfalls in the Albuquerque metropolitan area, New Mexico, 2003-12.

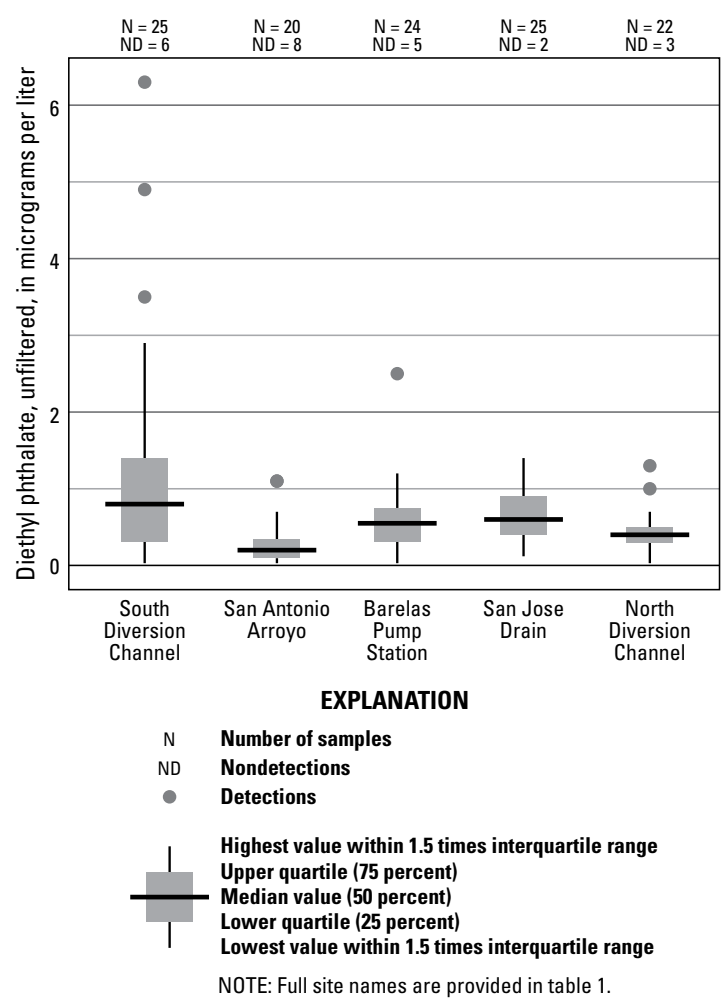

Figure 14. Diethyl phthalate concentrations in urban stormwater samples from five outfalls in the Albuquerque metropolitan area, New Mexico, 2003-12.

\section{Polycyclic Aromatic Hydrocarbons}

PAHs can be released into the environment from a variety of urban sources. Increasing PAH trends in urban streams have been linked to increased use of coal-tar products (sealcoats) on parking lots and other urban surfaces and the release of weathered and abraded sealcoat particles to streams (Mahler and others, 2012). Most PAHs are SVOCs, but some, such as naphthalene, are VOCs. Fifteen of the 16 PAHs that are listed in the EPA Priority Chemicals list (U.S. Environmental Protection Agency, 2014a) were detected in at least one outfall sample. The most frequently detected PAHs found in the stormwater samples were fluoranthene, phenanthrene, and pyrene (table 14). The Barelas Pump Station and North Diversion Channel outfalls generally had the highest median concentrations, and the San Antonio Arroyo outfall had the lowest median concentrations (figs. 15-17). Maximum concentrations for some PAHs in stormwater did exceed some NM WQSs.

A total of 10 PAHs were detected in stormwater samples from the South Diversion Channel outfall, 6 of which were detected in more than 10 percent of the stormwater samples. Benzo[a]pyrene, benzo[b]fluoranthene, benzo[k]fluoranthene, chrysene, and indeno[1,2,3-cd]pyrene had maximum concentrations at this site that exceeded either a domestic-water-supply or HH-OO standard (table 14).

A total of 5 PAHs were detected in stormwater samples from the San Antonio Arroyo outfall, with fluoranthene being the only constituent detected in more than 10 percent of the stormwater samples. Benzo[b]fluoranthene and chrysene had maximum concentrations that exceeded either a domesticwater-supply or HH-OO standard (table 14).

A total of 13 PAHs were detected in stormwater samples from the Barelas Pump Station outfall, 10 of which were detected in more than 10 percent of the stormwater samples. At this site, benzo[a]anthracene, benzo[a]pyrene, benzo[b]fluoranthene, benzo[k]fluoranthene, chrysene, and indeno[1,2,3-cd]pyrene had maximum concentrations that exceeded either a domestic-water-supply or HH-OO standard (table 14).

A total of 8 PAHs were detected in stormwater samples from the San Jose Drain outfall, 3 of which were detected in more than 10 percent of the stormwater samples. At this site, benzo[a]pyrene, benzo[b]fluoranthene, and chrysene had maximum concentrations that exceeded either a domesticwater-supply or HH-OO standard (table 14).

A total of 15 PAHs were detected in stormwater samples from the North Diversion Channel outfall, 12 of which were detected in more than 10 percent of the stormwater samples. At this site, seven PAHs - benzo[a] anthracene, benzo[a]pyrene, benzo[b]fluoranthene, benzo[k] fluoranthene, chrysene, dibenzo[a,h]anthracene, and indeno[1,2,3-cd]pyrene - had maximum concentrations that exceeded a domestic-water-supply or HH-OO standard (table 14). 


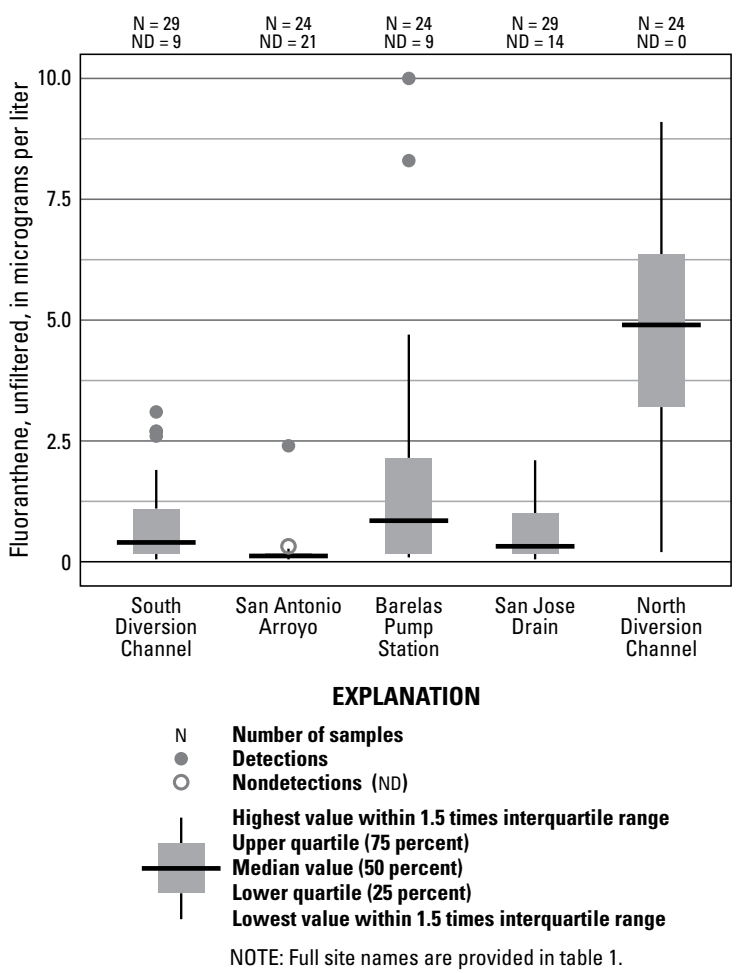

Figure 15. Fluoranthene concentrations in urban stormwater samples from five outfalls in the Albuquerque metropolitan area, New Mexico, 2003-12.

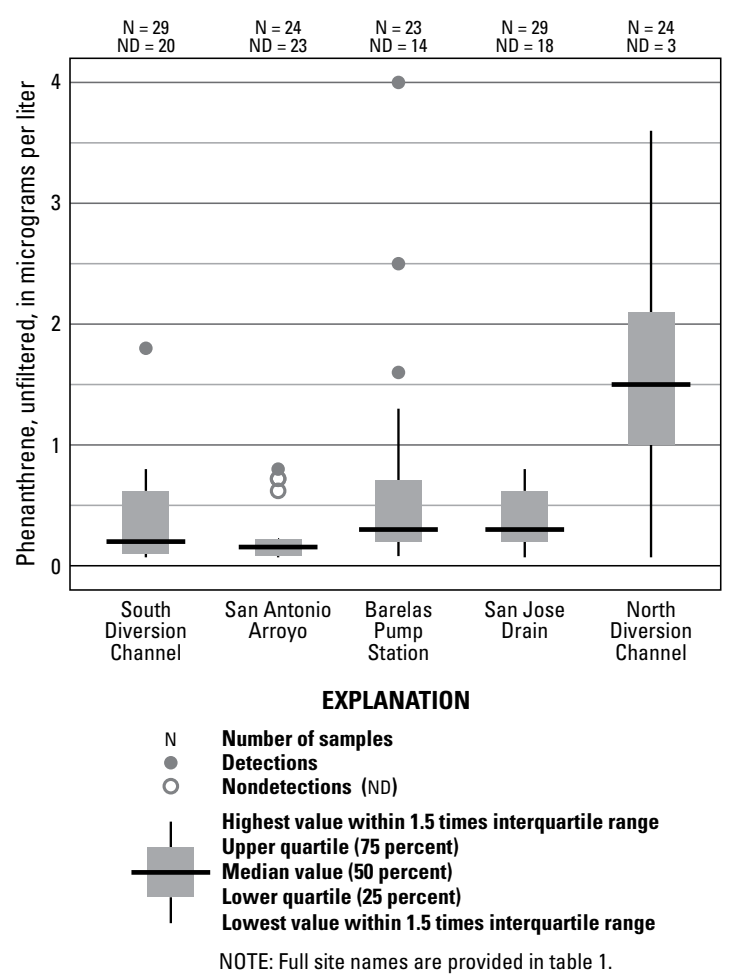

Figure 16. Phenanthrene concentrations in urban stormwater samples from five outfalls in the Albuquerque metropolitan area, New Mexico, 2003-12.
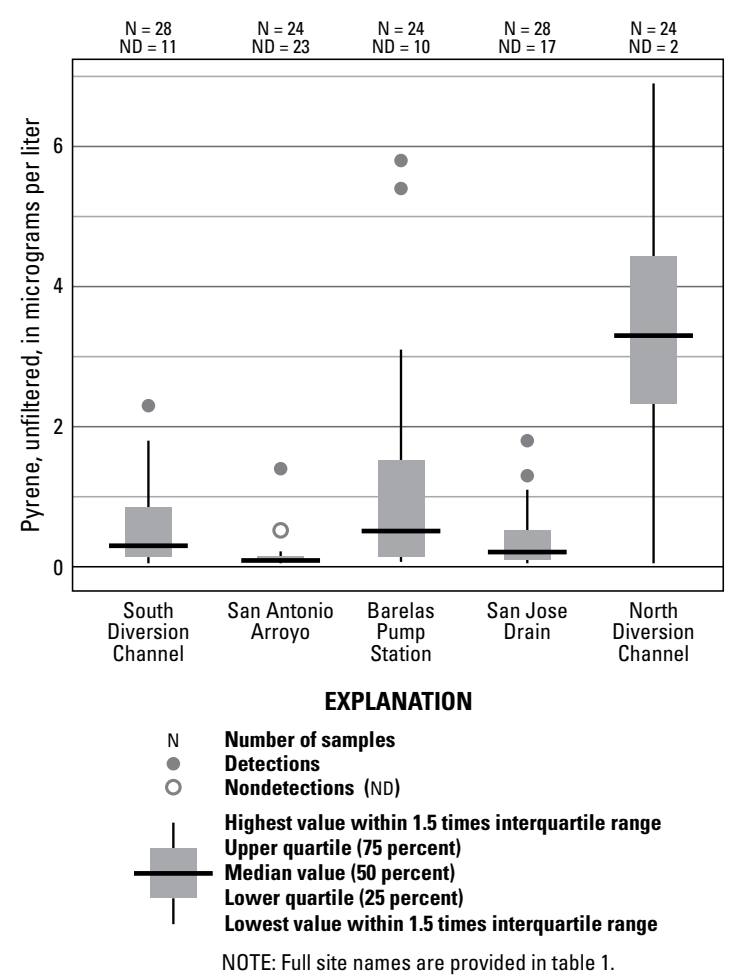

Figure 17. Pyrene concentrations in urban stormwater samples from five outfalls in the Albuquerque metropolitan area, New Mexico, 2003-12.

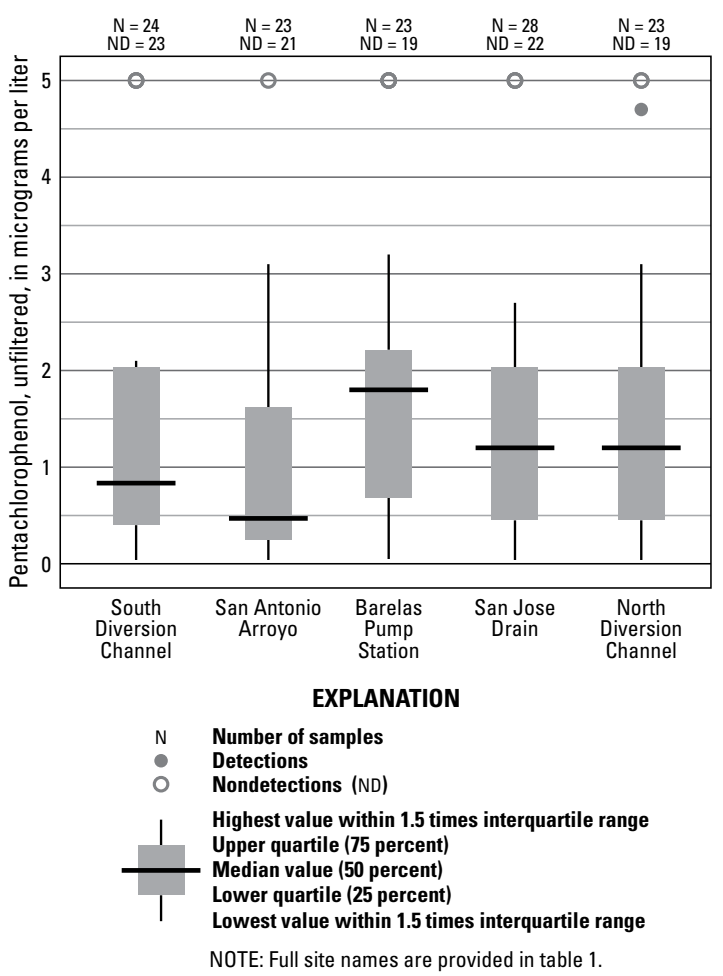

Figure 18. Pentachlorophenol concentrations in urban stormwater samples from five outfalls in the Albuquerque metropolitan area, New Mexico, 2003-12. 


\section{Pesticides}

The most frequently detected pesticide in the stormwater samples was pentachlorophenol. Pentachlorophenol is used as a pesticide, as a disinfectant, and commonly as a wood preservative (U.S. Environmental Protection Agency, 2014c). Pentachlorophenol was the only pesticide to exceed its domestic-water-supply standard of $1 \mu \mathrm{g} / \mathrm{L}$, but it was not detected in more than 21 percent of the stormwater samples at any one outfall. The Barelas Pump Station outfall had the highest median concentration of pentachlorophenol (fig. 18). Most of the other pesticides were not detected in more than 10 percent of the stormwater samples (table 15).

A total of four pesticides were detected at the South Diversion Channel outfall but not in more than about 7 percent of the stormwater samples. At this site, pentachlorophenol and dieldrin were the only pesticides that had maximum concentrations that exceeded a domestic-water-supply or HH-OO standard (table 15).

A total of five pesticides were detected at the San Antonio Arroyo outfall but not in more than about 18 percent of the stormwater samples. At this site, pentachlorophenol was the only pesticide that had a maximum concentration that exceeded a domestic-water-supply or HH-OO standard (table 15).

A total of four pesticides were detected at the Barelas Pump Station outfall but not in more than 17 percent of the stormwater samples. At this site, pentachlorophenol was the only pesticide that had median and maximum concentrations that exceeded a domestic-water-supply or HH-OO standard (table 15).

A total of three pesticides were detected at the San Jose Drain outfall but not in more than 21 percent of the stormwater samples. At this site, pentachlorophenol was the only pesticide that had median and maximum concentrations that exceeded a domestic-water-supply or HH-OO standard (table 15).

A total of five pesticides were detected at the North Diversion Channel outfall but not in more than about 17 percent of the stormwater samples. Pentachlorophenol was the only pesticide that had median and maximum concentrations that exceeded a domestic-water-supply or HH-OO standard (table 15).

\section{Polychlorinated Biphenyls}

PCBs are synthetic organic compounds of chlorine attached to biphenyl, which is a molecule composed of two benzene rings. There are 209 configurations (congeners) of PCBs, each having 1-10 chlorine atoms (most common are the International Union of Pure and Applied Chemistry congener numbers 28-180). Because of the environmental toxicity of PCBs and their classification as a persistent organic pollutant, PCB production was banned by the U.S. Congress in 1979 (U.S. Environmental Protection Agency, 2014d).
Prior to 1979, PCBs were used in electrical transformers and condensers, paint, hydraulic fluid, pesticides, ink, carbonless paper, and toilet paper.

Most commercial PCB mixtures are known in the United States by their industrial trade names. The most common trade name is Aroclor. Aroclors are mixtures of congeners. These were sold under trade names followed by a four-digit number. In general, the first two numbers refer to the number of carbon atoms in the biphenyl skeleton (for PCBs, this is 12); the second two numbers indicate the percentage of chlorine by mass in the mixture. Thus, Aroclor 1260 has 12 carbon atoms and contains 60 percent chlorine by mass. An exception is Aroclor 1016, which also has 12 carbon atoms but has 42 percent chlorine by mass. Different Aroclors were used at different times and for different applications. In electrical equipment manufacturing in the United States, Aroclor 1260 and Aroclor 1254 were the most commonly used mixtures before 1950; Aroclor 1242 was the most commonly used mixture in the 1950s and 1960s until it was phased out in 1971 and replaced by Aroclor 1016.

There are two common analytical tests for determining PCB concentrations. EPA analytical test method 8082 is used to determine the concentration of PCBs as Aroclors and has laboratory detection limits greater than or equal to $0.3 \mu \mathrm{g} / \mathrm{L}$. The seven Aroclors 1016, 1221, 1232, 1242, 1248, 1254 , and 1260 are commonly specified in EPA regulations. Although quantitation of PCBs as Aroclors is appropriate for many regulatory compliance determinations, it is particularly difficult when the Aroclors have been weathered by long exposure in the environment because the degraded Aroclors may have significant differences in peak patterns compared to the EPA Aroclor standards. Analyzing stormwater samples for congeners, rather than for Aroclors, can afford greater quantitative accuracy. EPA analytical test method 1668 analyzes for specific PCB congeners at a higher resolution than does EPA analytical test method 8082 and can have detection limits as low as 10 picograms per liter $(\mathrm{pg} / \mathrm{L})$. Total PCBs in a sample can be estimated by summation of the concentrations for the congeners.

PCBs as Aroclors were not detected when analyses were conducted by using EPA analytical test method 8082 in stormwater at any outfall. PCBs as congeners were detected when analyses were conducted by using EPA analytical test method 1668 in stormwater. Stormwater samples were not analyzed for PCBs by using EPA analytical test method 1668 until 2011. The highest total PCB congener concentrations in stormwater were at the North Diversion Channel and San Jose Drain outfalls (table 17). The lowest concentrations in stormwater were at the San Antonio Arroyo outfall. Total PCB congener concentrations in the Rio Grande upstream from the North Diversion Channel as measured at the Rio Grande at Albuquerque streamgage (fig. 1) were below the reporting limit of $420 \mathrm{pg} / \mathrm{L}$. PCBs in stormwater were detected but generally at low concentrations. 
Table 17. Total concentrations for polychlorinated biphenyl congeners in urban stormwater samples from five outfalls and the Rio Grande upstream from the North Diversion Channel in the Albuquerque metropolitan area, New Mexico, 2011-12.

[Full site names of Albuquerque metropolitan area sites are provided in table $1 ; \mathrm{pg} / \mathrm{L}$, picograms per liter]

\begin{tabular}{cc}
\hline $\begin{array}{c}\text { Date } \\
\text { sampled }\end{array}$ & $\begin{array}{c}\text { Total polychlorinated } \\
\text { biphenyl concentration (pg/L) } \\
\text { (sum of congeners) }\end{array}$ \\
\hline $8-24-2011$ & UR-200 - South Diversion Channel \\
$4-3-2012$ & 73 \\
$7-23-2012$ & 3,632 \\
$8-16-2012$ & 4,277 \\
\hline & 233 \\
\hline $9-1-2011$ & 1,241 \\
$10-5-2011$ & Not detected (reporting limits ranging from 42 to 420) \\
$4-3-2012$ & 134 \\
$7-5-2012$ & 147 \\
\hline \multicolumn{2}{c}{ UR-300 - San Antonio Arroyo } \\
\hline $7-20-2011$ & 17,580 \\
$8-24-2011$ & 229 \\
$9-1-2011$ & 8,888 \\
$9-12-2012$ & 33,503 \\
\hline & UR-500 - San Jose Drain \\
\hline $7-20-2011$ & 123,699 \\
$5-11-2012$ & 7,836 \\
$7-23-2012$ & 4,607 \\
\hline & UR-9900 - North Diversion Channel \\
\hline $8-3-2011$ & UR-330600- Tijeras Arroyo
\end{tabular}

8-3-2011 Not detected (reporting limits ranging from 42 to 420 )

4-3-2012

1,583

Rio Grande Upstream of North Diversion Channel (station 083296806)

7-29-2011 Not detected (reporting limits ranging from 44 to 440)

8-18-2011 Not detected (reporting limits ranging from 44 to 440 )

\section{Bacteria}

Fecal-coliform bacteria are a group of moderately heat-tolerant coliform bacteria abundant in the intestines of warm-blooded animals (Parsons, Inc., 2005). Because they are easy to measure, they are used as an indicator of the possible presence of fecal pathogenic microorganisms in water, including other bacteria, viruses, and harmful protozoans. Most fecal-coliform bacteria are not pathogenic. Escherichia coli (E. coli) is often the most abundant species of the fecal-coliform group of bacteria, and a few strains of $E$. coli are pathogenic. Fecal-coliform bacteria including E. coli typically are reported either as colony-forming units per 100 milliliters (cfu/100 mL) or as most probable number per 100 milliliters (MPN/100 mL). To protect against primary contact, the NM WQS for fecal-coliform bacteria are based on the concentration of E. coli of $410 \mathrm{cfu} / 100 \mathrm{~mL}$.

In addition to the six major outfalls (South Diversion Channel, San Antonio Arroyo, Barelas Pump Station, San Jose Drain, Tijeras Arroyo, and North Diversion Channel), stormwater bacteria samples were also collected from the three other outfalls: Embudo Arroyo, Bear Arroyo, and Hahn Arroyo (fig. 1; table 18). Median densities of $E$. coli were above the NM WQS at the nine outfalls (fig. 19). Median $E$. coli densities were highest at the Barelas Pump Station, San Jose Drain, and South Diversion Channel outfalls (table 18). The other outfalls had median and (or) mean E. coli densities near to or lower than that measured at the background site, with the San Antonio Arroyo outfall having the lowest median density. Densities of $E$. coli in the stormwater samples often exceeded the NM WQS.

A microbial source tracking (MST) study funded by the New Mexico Environment Department, AMAFCA, and Bernalillo County Public Works Natural Resource Services investigated specific sources of fecal coliform causing high levels of bacteria in the Middle Rio Grande (Parsons, Inc., 2005). Some conclusions of the MST study include the following:

- For the Middle Rio Grande, human, pet, and livestock sources accounted for approximately 54 percent of fecal coliform. Wildlife (primarily avian) accounted for approximately 46 percent.

- The highest fecal-coliform densities resulted from the influence of stormwater. Densities ranged from a low of $27 \mathrm{cfu} / 100 \mathrm{~mL}$ at an Angostura Diversion Dam (not shown on fig. 1; located on the Rio Grande approximately 15 mi upstream from the Albuquerque metropolitan area) to a high of more than 1 million cfu/100 $\mathrm{mL}$ just upstream from the North Diversion Channel discharge to the Rio Grande.

- The geometric mean fecal-coliform densities were strongly related to the human population density of the watershed. Fecal-coliform densities were inversely related to cropland density and household agricultural income and were not significantly related to septic tank density, indicating that agricultural sources and septic tank malfunctions may not be major sources of fecal coliform in runoff. 
Table 18. Statistical summary of bacteria densities in urban stormwater samples from nine outfalls in the Albuquerque metropolitan area, New Mexico, 2003-12.

[Full site names are provided in table 1. MPN/100 mL, most probable number per 100 milliliters; MAD, mean absolute deviation; median and maximum concentrations presented in bold exceed a New Mexico water-quality standard (as described in State of New Mexico Standards for Interstate and Intrastate Surface Waters [20.6.4 New Mexico Administrative Code])]

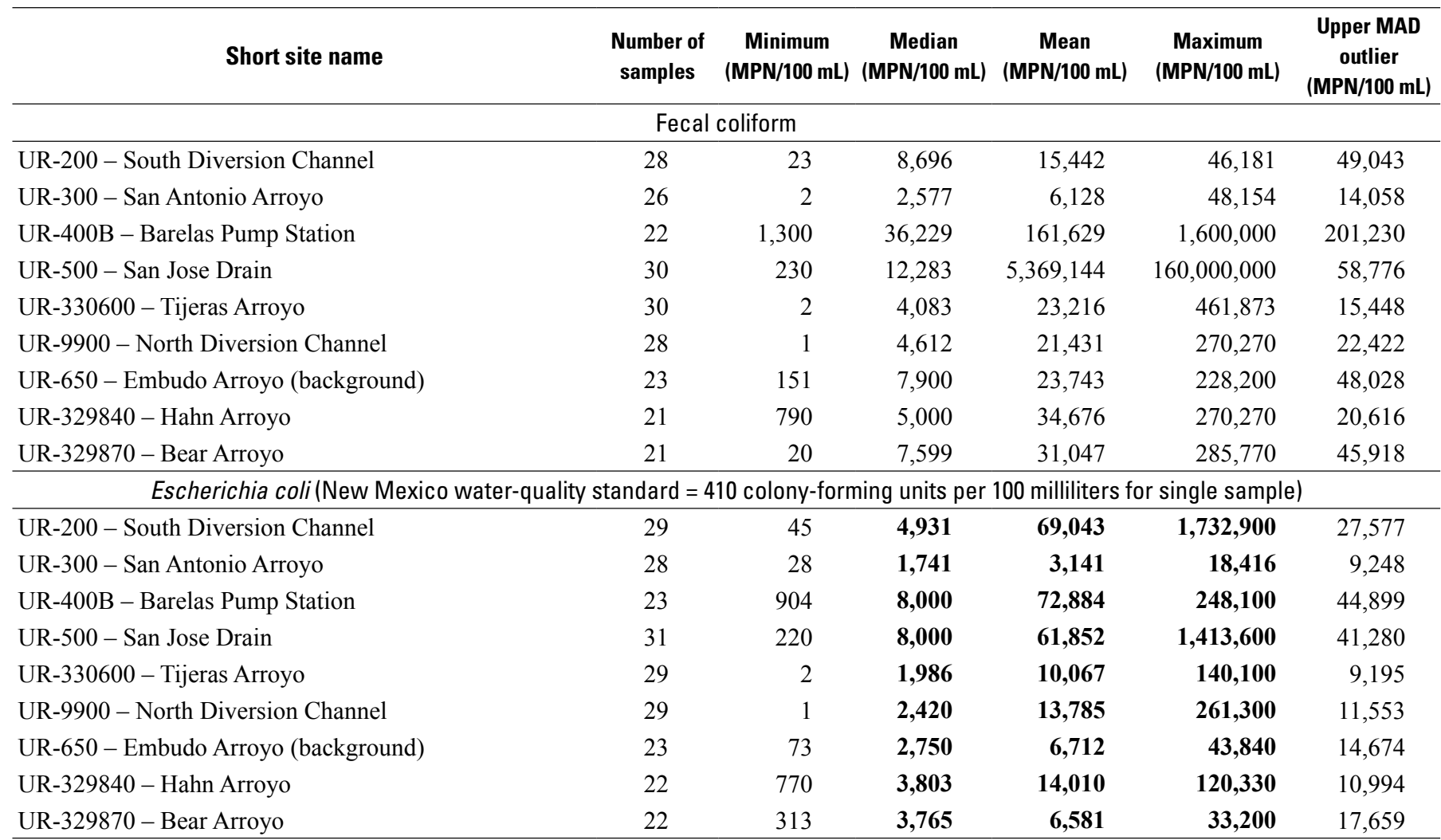

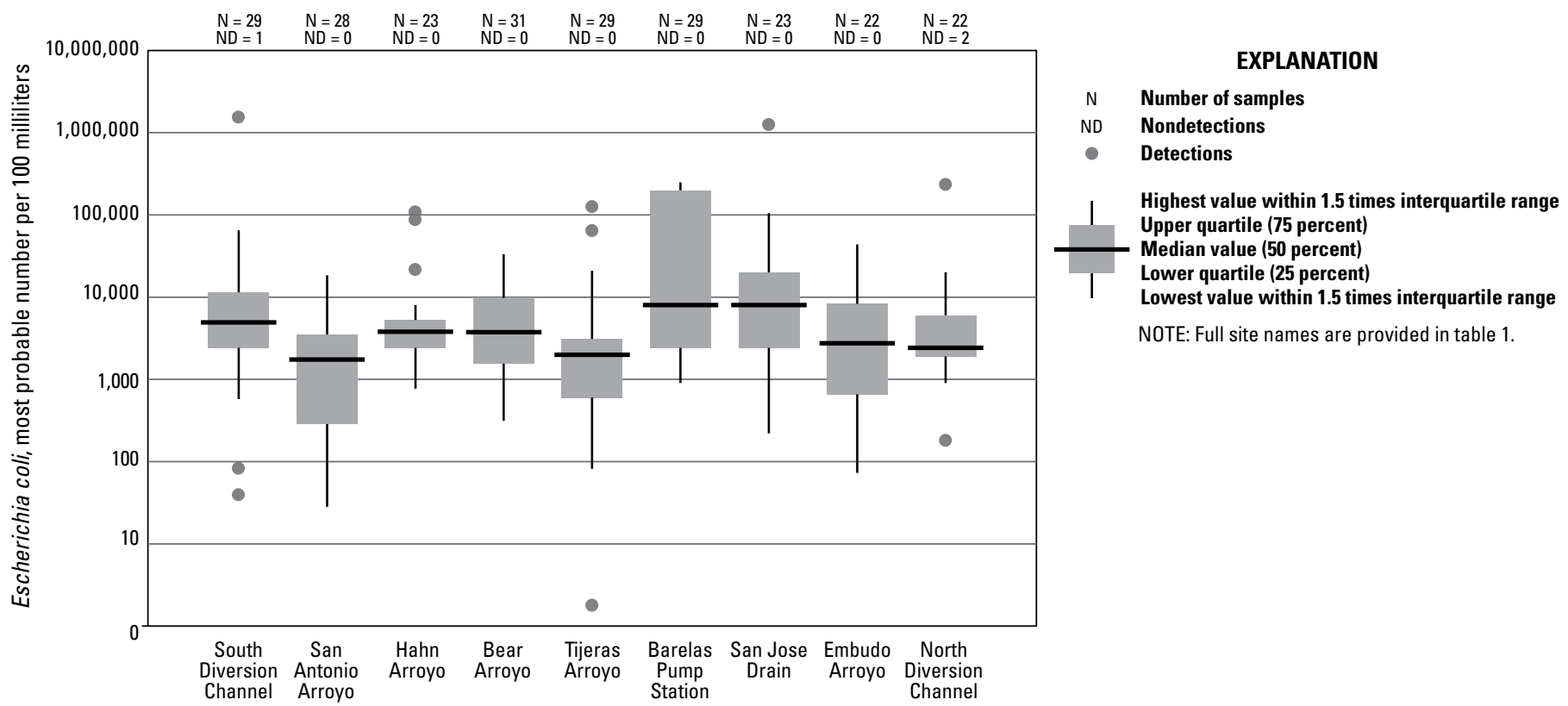

Figure 19. Escherichia coli bacteria densities in urban stormwater samples from nine outfalls in the Albuquerque metropolitan area, New Mexico, 2003-12. 


\section{Comparison of Quality of Albuquerque Urban Stormwater With That of Stormwater From Other Western U.S. Cities}

The quality of stormwater from the outfalls in the Albuquerque metropolitan area was compared with stormwater quality in other arid and semiarid regions (annual precipitation of less than 16 in.) in the Western United States (table 19). Through a literature search, urban-stormwaterquality studies of six other major metropolitan areas in the Western United States were found for comparison, including Phoenix (Lopes and others, 1995), Tucson (Pitt and others, 2008), Boise (Kjelstrom, 1995), Denver (Stevens and Slaughter, 2012), Salt Lake City (Stantec Consulting, 2009), and Las Vegas (Montgomery Watson Harza, 2004). The waterquality constituents analyzed in these studies were generally limited to suspended solids, BOD, COD, nutrients, metals, and bacteria. Water-quality data for the Tijeras Arroyo and Embudo Arroyo outfalls in Albuquerque were included in the bacteria comparisons because the sample sizes were sufficient to determine meaningful median concentrations. In general, water-quality data for the other Western U.S. cities exhibited the same broad range in median constituent concentrations as did data for stormwater from the Albuquerque outfalls observed in this study.

Median concentrations for suspended solids for stormwater samples from the Albuquerque outfalls generally were higher than those for stormwater from the other Western U.S. cities, with the exception of Las Vegas (fig. 20A). Stormwater from Las Vegas had a median suspended solids concentration of $885 \mathrm{mg} / \mathrm{L}$, which exceeded the median suspended solids concentration for stormwater from all Albuquerque outfalls except for the North Diversion Channel (UR-9900), which had a median suspended solids concentration of $1,520 \mathrm{mg} / \mathrm{L}$ (fig. 20A). The median concentrations for BOD and COD in stormwater samples from the Albuquerque outfalls were similar to the median concentrations for BOD and COD in stormwater from the other Western U.S. cities (fig. 20A).
Median concentrations for total phosphorus in stormwater samples from the Albuquerque outfalls, except for the San Antonio Arroyo (UR-300), generally were higher than were median concentrations in stormwater from the other Western U.S. cities. Median concentrations for dissolved phosphorus in stormwater samples from the Albuquerque outfalls were in the same range as those in stormwater from the other Western U.S. cities (fig. 20B). Median concentrations for orthophosphate in stormwater samples from the Albuquerque outfalls were in the same range as those in stormwater for the Denver sites and lower than those for Las Vegas (fig. 20B). Orthophosphate data or detections were not available for the other Western U.S. cities.

Median concentrations for nitrogen-based nutrients (total ammonia plus organic nitrogen, dissolved ammonia, and dissolved nitrate plus nitrite) in stormwater samples from the Albuquerque outfalls were similar to those in stormwater from the other Western U.S. cities (fig. 20C).

Median concentrations for the metals copper, lead, and zinc in stormwater samples from the Albuquerque outfalls were similar to those in stormwater from the other Western U.S. cities (figs. $20 D$ and 20E). Median concentrations for total zinc in stormwater samples from the Albuquerque outfalls were in the range of those from the other Western U.S. cities, except for the median concentration at the Barelas Pump Station outfall (UR-400B), which is at least 1.5 times higher than median concentrations for total zinc at the other Albuquerque outfalls and in the other Western U.S. cities. Median dissolved lead concentrations in stormwater samples from the Albuquerque outfalls generally were lower than median dissolved lead concentrations in stormwater samples from the other Western U.S. cities, except Denver and Salt Lake City.

The median densities for bacteria (E. coli and fecal coliform) in stormwater samples from the Albuquerque outfalls, except for the San Antonio Arroyo outfall (UR-300), were higher than those in stormwater from the other Western U.S. cities, except for Las Vegas (fig. 20F). The San Antonio Arroyo outfall had bacteria concentrations that were near to or lower than bacteria concentrations found in Phoenix, Boise, and Denver. There were no bacteria data available for Tucson. 
Table 19. Comparison of median concentrations for selected constituents in urban stormwater samples at outfalls in the Albuquerque metropolitan area with median concentrations for selected constituents in stormwater for selected Western U.S. cities, New Mexico, 2003-12.

[Full site names for the Albuquerque metropolitan area sites are provided in table 1. mg/L, milligrams per liter; N, nitrogen; $<$, less than; MPN/100 mL, most probable number per $100 \mathrm{milliliters;} \mu \mathrm{g} / \mathrm{L}$, micrograms per milliliter

\begin{tabular}{|c|c|c|c|c|c|c|c|c|c|c|c|c|c|c|c|}
\hline \multirow{2}{*}{ Constituent } & \multicolumn{7}{|c|}{ Albuquerque metropolitan area } & \multirow{2}{*}{$\begin{array}{l}\text { Phoenix, } \\
\text { Arizona' }\end{array}$} & \multirow{2}{*}{$\begin{array}{l}\text { Tucson, } \\
\text { Arizona }^{2}\end{array}$} & \multirow{2}{*}{$\begin{array}{l}\text { Boise, } \\
\text { Idaho }^{3}\end{array}$} & \multicolumn{2}{|c|}{ Denver, Colorado ${ }^{4}$} & \multicolumn{2}{|c|}{$\begin{array}{c}\text { Salt Lake City, } \\
\text { Utah }^{5}\end{array}$} & \multirow{2}{*}{$\begin{array}{c}\text { Las } \\
\text { Vegas, } \\
\text { Nevada }^{6}\end{array}$} \\
\hline & UR-200 & UR-300 & UR-400B & UR-500 & UR-650 & UR-9900 & $\begin{array}{c}\text { UR- } \\
330600\end{array}$ & & & & Station 1 & Station 2 & Station 1 & Station 2 & \\
\hline \multicolumn{16}{|c|}{ Physical parameters (mg/L) } \\
\hline Suspended solids & 664.00 & 36.50 & 326.00 & 404.00 & No data & $1,520.00$ & No data & 187.5 & 138 & 79 & 597 & 236 & 108 & 194 & 885 \\
\hline $\begin{array}{l}\text { Biochemical } \\
\text { oxygen demand }\end{array}$ & 15.00 & 12.00 & 25.00 & 23.50 & No data & 16.10 & No data & 30 & 42 & 51 & No data & No data & 17.5 & 16 & 35 \\
\hline $\begin{array}{l}\text { Chemical oxygen } \\
\text { demand }\end{array}$ & 171.00 & 78.00 & 224.00 & 225.50 & No data & 220.00 & No data & 120 & 227.5 & 180 & No data & No data & 117 & 120 & 230 \\
\hline \multicolumn{16}{|c|}{ Nutrients $(\mathrm{mg} / \mathrm{L})$} \\
\hline $\begin{array}{l}\text { Ammonia } \\
\text { plus organic } \\
\text { nitrogen, total, } \\
\text { as N }\end{array}$ & 2.12 & 1.20 & 3.44 & 3.65 & No data & 2.86 & No data & 1.7 & 3.5 & 3.7 & 1.4 & 2 & 3.08 & 2.1 & No data \\
\hline $\begin{array}{l}\text { Ammonia, } \\
\text { dissolved, as N }\end{array}$ & 0.24 & 0.28 & 0.61 & 0.62 & No data & 0.57 & No data & 0.39 & No data & 1.1 & 0.09 & 0.09 & 0.9 & 1.00 & 0.6 \\
\hline $\begin{array}{c}\text { Nitrate plus nitrite, } \\
\text { dissolved, as N }\end{array}$ & 0.62 & 0.42 & 0.82 & 0.86 & No data & 0.61 & No data & 0.95 & 1.2 & 0.71 & 0.59 & 0.08 & 0.96 & 0.74 & 1.9 \\
\hline $\begin{array}{l}\text { Orthophosphate, } \\
\text { dissolved, as P }\end{array}$ & 0.10 & 0.14 & 0.13 & 0.17 & No data & 0.14 & No data & No data & No data & No data & 0.013 & 0.089 & $<0.2$ & $<0.5$ & 0.18 \\
\hline $\begin{array}{l}\text { Phosphorus, } \\
\text { dissolved, as P }\end{array}$ & 0.09 & 0.16 & 0.21 & 0.40 & No data & 0.14 & No data & 0.115 & No data & 0.31 & No data & No data & No data & No data & 0.96 \\
\hline $\begin{array}{l}\text { Phosphorus, total, } \\
\text { as P }\end{array}$ & 0.81 & 0.25 & 0.71 & 0.80 & No data & 1.30 & No data & 0.295 & 0.55 & 0.54 & 0.22 & 0.63 & 0.49 & 0.603 & 0.18 \\
\hline \multicolumn{16}{|c|}{ Metals $(\mu \mathrm{g} / \mathrm{L})$} \\
\hline Copper, dissolved & 5.12 & 5.00 & 7.31 & 5.83 & No data & 5.38 & No data & 10 & No data & No data & 2.2 & 2.4 & 18 & 19 & 10 \\
\hline Copper, total & 38.90 & 9.10 & 48.60 & 35.10 & No data & 39.90 & No data & 33 & 5.3 & 20 & 8.3 & 17 & 37 & 56 & 44 \\
\hline Lead, dissolved & 2.00 & 2.00 & 2.00 & 2.00 & No data & 2.00 & No data & No data & 36 & No data & 0.08 & 0.14 & $<0.03$ & 30 & $<100$ \\
\hline Lead, total & 45.30 & 2.30 & 77.00 & 53.30 & No data & 50.50 & No data & 35.5 & 36 & 42 & 3.45 & 14.5 & 43 & 100 & 86 \\
\hline Zinc, dissolved & 5.00 & 10.40 & 35.20 & 17.35 & No data & 12.40 & No data & 16.5 & No data & No data & 33 & 10.9 & 44 & 79 & 23 \\
\hline Zinc, total & 160.00 & 37.00 & 456.00 & 339.00 & No data & 283.00 & No data & 260 & 245 & 260 & 33 & 75 & 20 & 270 & 230 \\
\hline \multicolumn{16}{|c|}{ Bacteria (MPN/100 mL) } \\
\hline $\begin{array}{l}\text { Escherichia coli } \\
\text { Fecal coliform }\end{array}$ & $\begin{array}{l}4,931 \\
8,696\end{array}$ & $\begin{array}{l}1,741 \\
2,577\end{array}$ & $\begin{array}{r}8,000 \\
36,229\end{array}$ & $\begin{array}{r}8,000 \\
12,283\end{array}$ & $\begin{array}{l}2,750 \\
7,900\end{array}$ & $\begin{array}{l}2,420 \\
4,612\end{array}$ & $\begin{array}{l}1,986 \\
4,083\end{array}$ & $\begin{array}{l}\text { No data } \\
4,500\end{array}$ & $\begin{array}{l}\text { No data } \\
\text { No data }\end{array}$ & \begin{tabular}{|l} 
No data \\
2,170
\end{tabular} & $\begin{array}{l}3,300 \\
3,300\end{array}$ & $\begin{array}{l}2,950 \\
2,140\end{array}$ & $\begin{array}{l}\text { No data } \\
130\end{array}$ & $\begin{array}{l}\text { No data } \\
\text { No data }\end{array}$ & $\begin{array}{l}\text { No data } \\
24,000\end{array}$ \\
\hline \multicolumn{16}{|c|}{${ }^{1}$ From Lopes and others (1995). } \\
\hline \multicolumn{16}{|c|}{${ }^{2}$ From Pitt and others (2008). } \\
\hline \multicolumn{16}{|c|}{${ }^{3}$ From Kjelstrom (1995). } \\
\hline \multicolumn{16}{|c|}{${ }^{4}$ From Stevens and Slaughter (2012). } \\
\hline \multicolumn{16}{|c|}{${ }^{5}$ From Stantec Consulting (2009). } \\
\hline OIII & & & & & & & & & & & & & & & \\
\hline
\end{tabular}




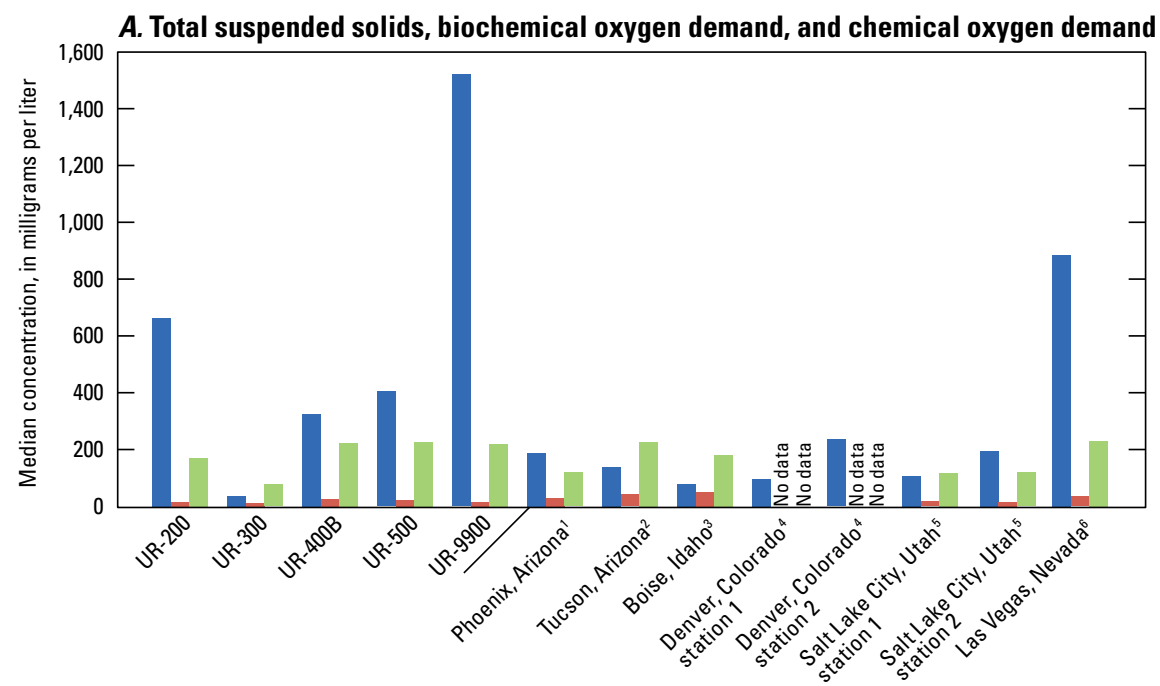

\section{EXPLANATION}

- Total suspended solids

- Biochemical oxygen demand

- Chemical oxygen demand

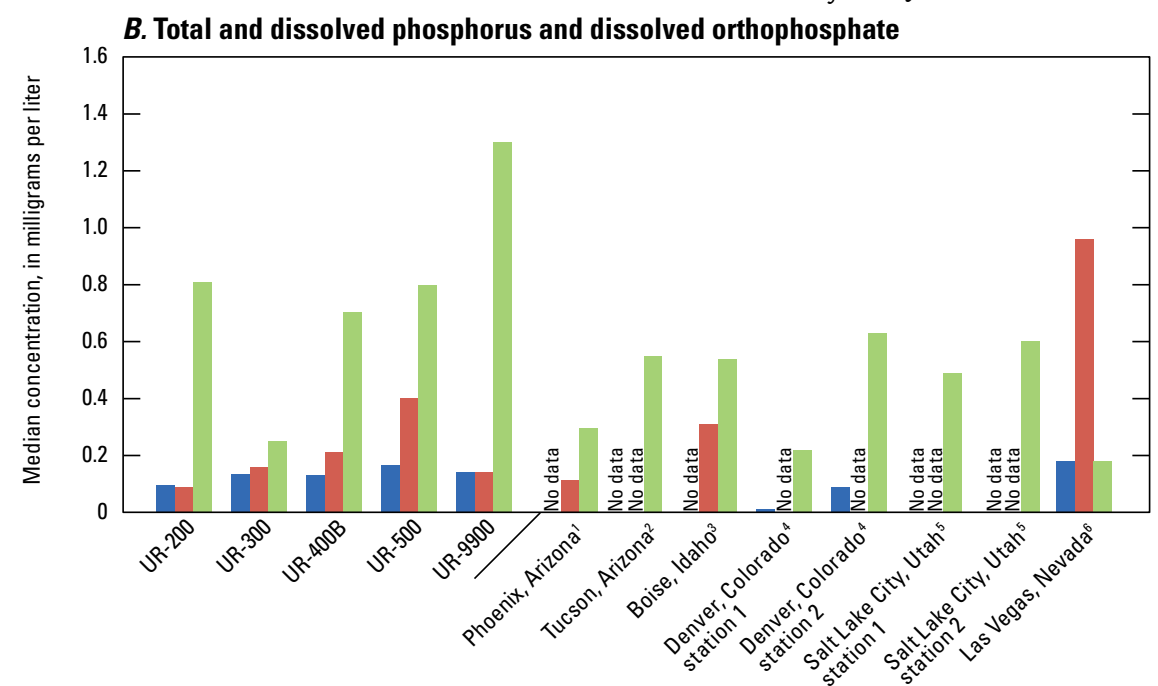

C. Total and dissolved nitrogen-based nutrients

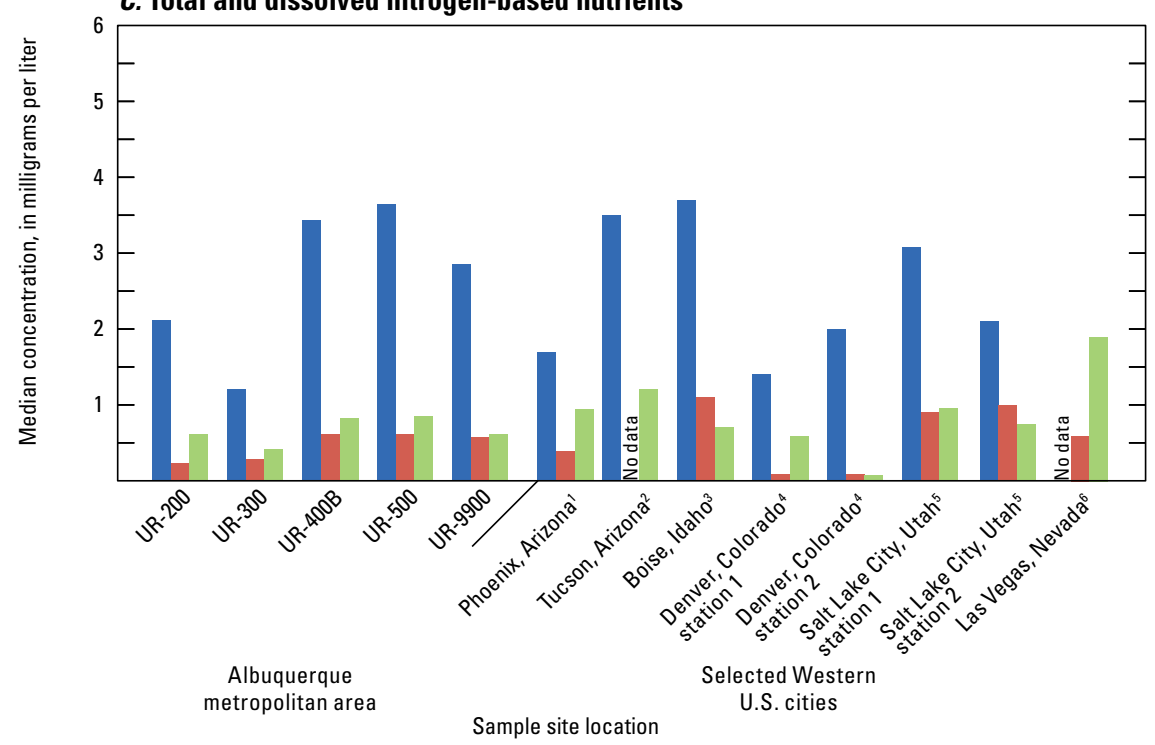

\section{EXPLANATION}

Ammonia plus organic nitrogen, total, as $\mathrm{N}$

Ammonia, dissolved, as $\mathrm{N}$

Nitrate plus nitrite, dissolved, as $\mathrm{N}$

Figure 20. Comparison of median concentrations for selected constituents in urban stormwater samples at outfalls in the Albuquerque metropolitan area, New Mexico, with median concentrations for selected constituents in stormwater for other selected Western U.S. cities, 2003-12. $A$, Total suspended solids, biochemical oxygen demand, and chemical oxygen demand. $B$, Total and dissolved phosphorus and dissolved orthophosphate. $C$, Total and dissolved nitrogen-based nutrients. D, Total copper, lead, and zinc. E, Dissolved copper, lead, and zinc. F, Escherichia coli and fecal-coliform bacteria. 


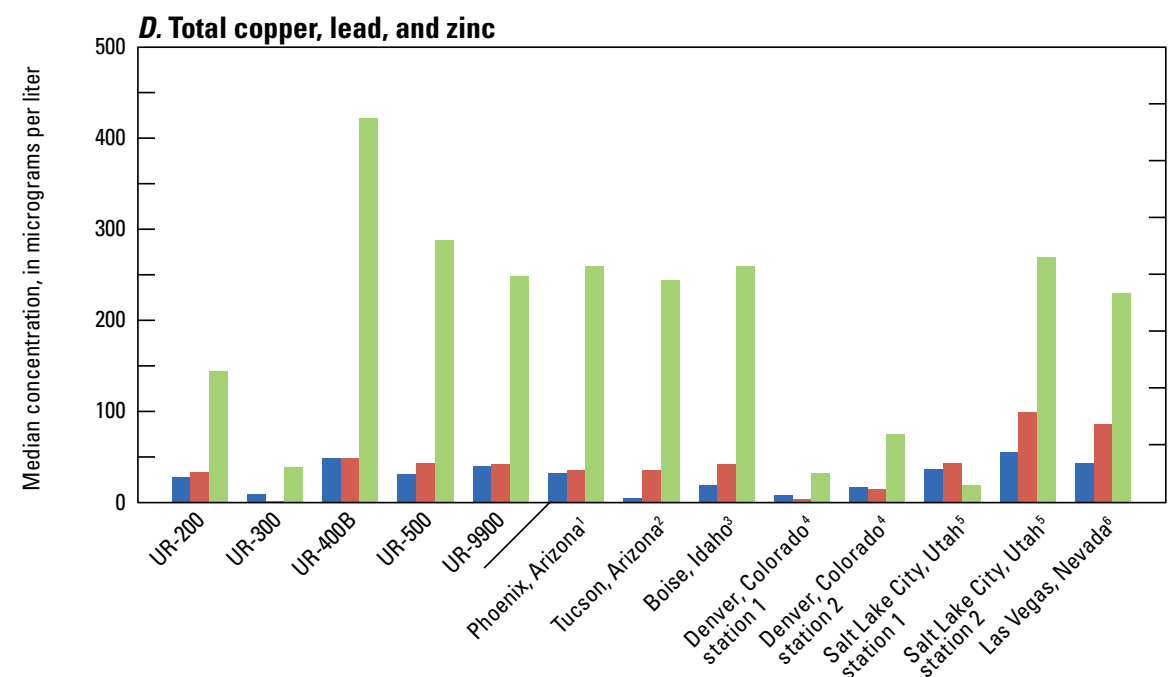

EXPLANATION

- Copper, total

- Lead, total

Zinc, total

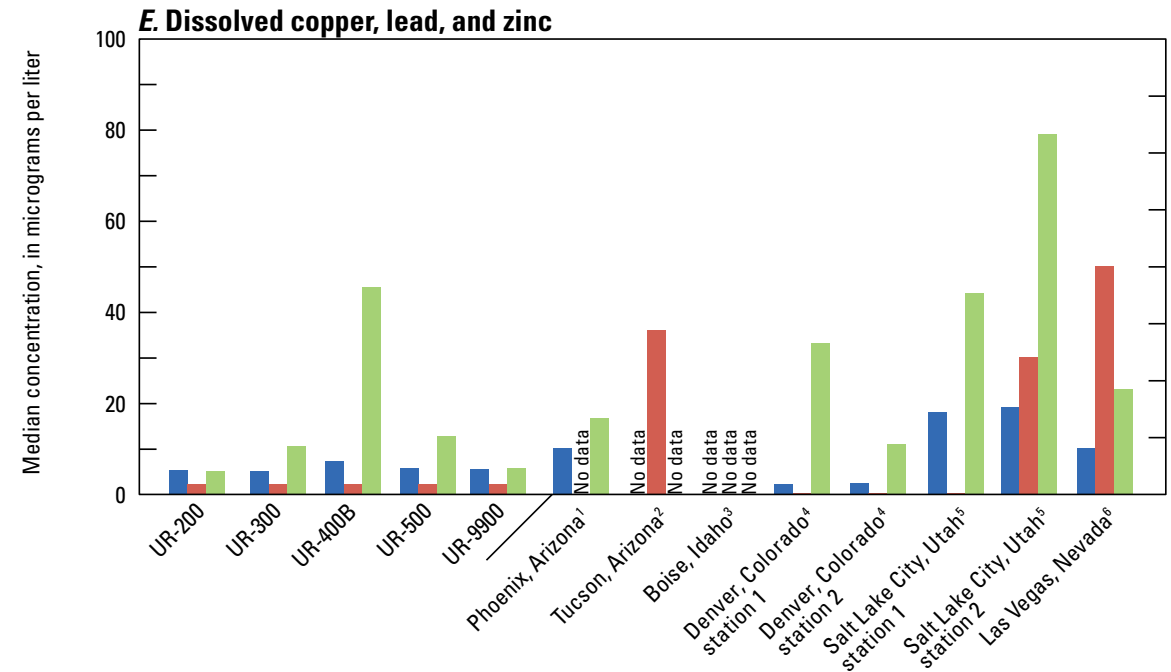

\section{EXPLANATION}

Copper, dissolved

Lead, dissolved

Zinc, dissolved

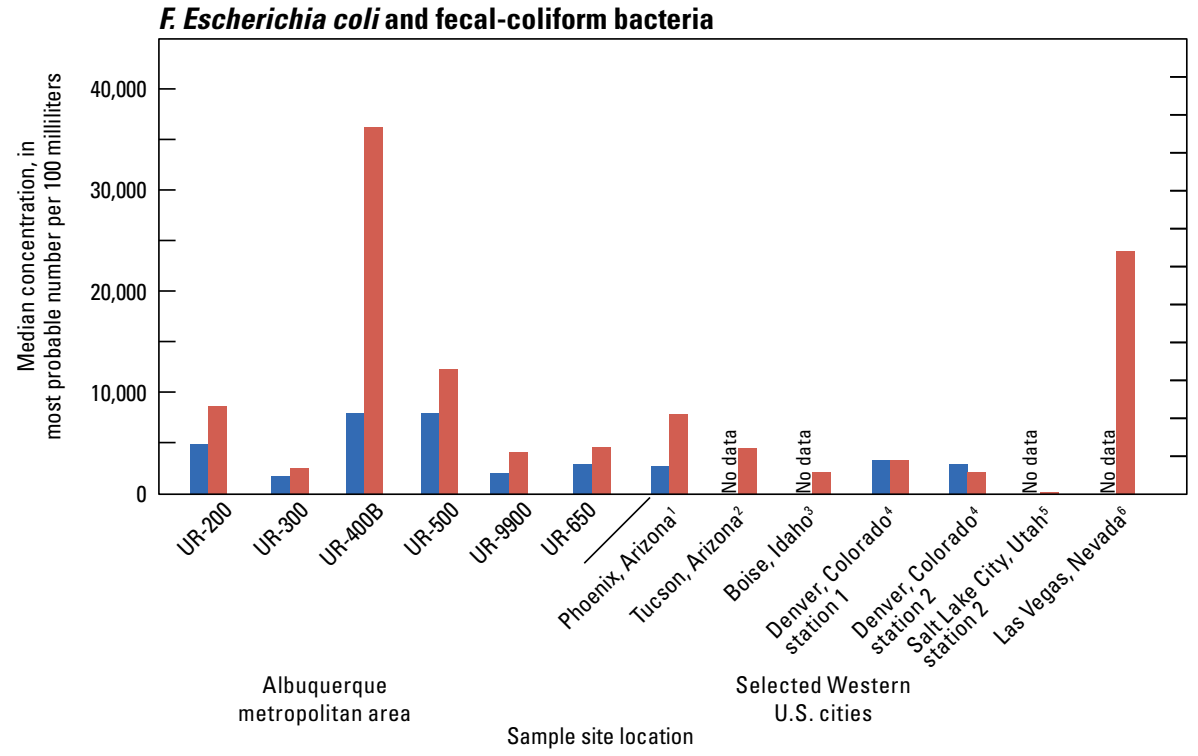

EXPLANATION

Escherichia coli

Fecal-coliform bacteria
NOTE: Full site names for the Albuquerque metropolitan area sites are provided in table 1.

'From Lopes and others (1995). 2From Pitt and others (2008).

${ }^{3}$ From Kjelstrom (1995).

${ }^{4}$ From Stevens and Slaughter (2012).

${ }^{5}$ From Stantec Consulting (2009).

${ }^{6}$ From Montgomery Watson Harza (2004).

Figure 20. Graphs showing comparison of median concentrations for selected constituents in urban stormwater samples at outfalls in the Albuquerque metropolitan area, New Mexico, with median concentrations for selected constituents in stormwater for other selected Western U.S. cities, 2003-12. $A$, Total suspended solids, biochemical oxygen demand, and chemical oxygen demand. $B$, Total and dissolved phosphorus and dissolved orthophosphate. $C$, Total and dissolved nitrogen-based nutrients. $D$, Total copper, lead, and zinc. E, Dissolved copper, lead, and zinc. F, Escherichia coli and fecal-coliform bacteria.-Continued 


\section{Summary}

Urban stormwater in the Albuquerque metropolitan area was sampled by the U.S. Geological Survey in cooperation with the City of Albuquerque, the Albuquerque Metropolitan Arroyo Flood Control Authority, the New Mexico Department of Transportation, and the University of New Mexico at a network of monitoring stations from 2003 to 2012 to meet regulatory requirements for the application phase of a National Pollutant Discharge Elimination System stormwater permit. During the study period, stormwater was sampled in the Albuquerque metropolitan area at outfalls from nine drainage basins with residential, industrial, commercial, agricultural, and undeveloped (agricultural and open space) land uses. Stormwater samples were analyzed for selected physical and chemical characteristics, nutrients, major ions, metals, organic compounds, and bacteria.

Median concentrations for selected physical and chemical constituents, such as $\mathrm{pH}$, specific conductance, dissolved solids, suspended solids, biochemical oxygen demand (BOD), and chemical oxygen demand (COD), were higher in stormwater samples from basins that have higher degrees of urban development (industrial, commercial, and residential) than in stormwater samples from those with lower degrees of urban development. High concentrations for BOD, suspended solids, or specific conductance were detected in stormwater samples from the North Diversion Channel near Alameda (hereinafter referred to as "North Diversion Channel") outfall, which receives stormwater from an area with high residential land use, and the City of Albuquerque Barelas Lift Station no. 32 (hereinafter referred to as "Barelas Pump Station") and San Jose Drain at Woodward Road at Albuquerque (hereinafter referred to as "San Jose Drain") outfalls, which receive stormwater from an area with high industrial and commercial land uses. Stormwater samples from the Mariposa Diversion of San Antonio Arroyo (hereinafter referred to as "San Antonio Arroyo") outfall, which receives stormwater from a comparatively less developed area of the city, generally had lower median concentrations for most physical characteristics compared with the stormwater samples from the other outfalls in this study.

With the exception of total phosphorus, nutrient concentrations in stormwater samples were generally low for all of the sampled Albuquerque outfalls. Median concentrations for total phosphorus in stormwater samples ranged from 0.25 milligrams per liter $(\mathrm{mg} / \mathrm{L})$ at the San Antonio Arroyo outfall to $1.30 \mathrm{mg} / \mathrm{L}$ at the North Diversion Channel outfall.

Median concentrations for major ions in stormwater samples from the outfalls corresponded closely with those of the Rio Grande at Albuquerque streamgage. Median concentrations for chloride and sulfate in the stormwater samples tended to be lower than concentrations for chloride and sulfate for the Rio Grande at Albuquerque streamgage for the years 1969-90.
Maximum dissolved aluminum, arsenic, chromium (VI), and lead concentrations were the only metals in the stormwater samples that exceeded New Mexico water-quality standards (NM WQSs); however, these concentrations were determined to be data outliers. The median dissolved concentrations for aluminum, chromium (VI), and lead for stormwater samples from the Albuquerque outfalls were below the NM WQSs for aquatic life toxicity. The median concentration of arsenic for stormwater samples from the Albuquerque outfalls was below the NM WQS for drinking water. Dissolved beryllium, dissolved mercury, and dissolved thallium were not detected in any stormwater samples from the Albuquerque outfalls. The highest metal concentrations generally were detected in stormwater samples from the Barelas Pump Station, San Jose Drain, and North Diversion Channel outfalls.

Of the nearly 200 organic compounds that were analyzed for in this study, less than one-third (58 constituents) were positively identified at or above the analytical detection limit at any of the Albuquerque outfalls. The most frequently detected volatile organic compounds (VOCs) in stormwater samples from the outfalls were acetone, ethyl methyl ketone, trihalomethanes, and xylene; however, dichloromethane was the only VOC that exceeded an NM WQS.

The most frequently detected semivolatile organic compounds (SVOCs) in stormwater samples from the outfalls were bis(2-ethylhexyl) phthalate, di-n-butyl phthalate, and diethyl phthalate. Benzidine was the only SVOC that exceeded an NM WQS and was detected only in stormwater samples from the Barelas Pump Station outfall.

Fifteen of the 16 polycyclic aromatic hydrocarbons (PAHs) that are listed on the U.S. Environmental Protection Agency Priority Chemicals list were detected in at least one sample at each outfall. The most frequently detected PAHs in stormwater samples from the outfalls were fluoranthene, phenanthrene, and pyrene. Benzo[a]anthracene, benzo[a] pyrene, benzo[b]fluoranthene, benzo[k]fluoranthene, chrysene, dibenzo[a]anthracene, and indeno[1,2,3-cd]pyrene had median concentrations that exceeded either an NM WQS for domestic water supply or a human health-organism only standard.

Pesticides were rarely detected, with pentachlorophenol being the most frequently detected but never detected in more than about 21 percent of the stormwater samples at any one outfall.

Polychlorinated biphenyls (PCBs) as Aroclors were not detected when analyses were conducted by using EPA analytical test method 8082 in stormwater samples. PCBs as congeners were detected when analyses were conducted by using EPA analytical test method 1668 in stormwater samples. The highest total PCB congener concentrations in stormwater samples were at the North Diversion Channel and San Jose Drain outfalls, whereas the lowest were at the San Antonio Arroyo outfall. Total PCB congener concentrations in the Rio Grande upstream from the North Diversion Channel were below the reporting limit of 420 picograms per liter. PCBs in stormwater samples were detected but generally at low concentrations. 
Median densities for Escherichia coli (E. coli) bacteria in stormwater samples from the Albuquerque outfalls including the background location (Embudo Arroyo) were above the NM WQS. Bacteria densities were highest in stormwater samples from the Barelas Pump Station, San Jose Drain, and South Diversion Channel above Tijeras Arroyo outfalls and lowest at the San Antonio Arroyo outfall. Concentrations for E. coli in stormwater samples from the outfalls often exceeded the NM WQS.

The quality of stormwater samples from the Albuquerque metropolitan area was compared with that of six other Western U.S. cities (Phoenix, Arizona; Tucson, Arizona; Las Vegas, Nevada; Denver, Colorado; Salt Lake City, Utah; and Boise, Idaho) for a selected set of constituents. In general, waterquality data from these six other Western U.S. metropolitan areas were similar to the Albuquerque stormwater data. Median concentrations for suspended solids, total phosphorus, and bacteria (E. coli and fecal coliform) in stormwater samples from the Albuquerque outfalls generally were higher than median concentrations in stormwater samples from the other Western U.S. cities except for Las Vegas. The median concentrations of BOD, COD, nitrogen-based nutrients, dissolved phosphorus, and the metals copper, lead, and zinc in the stormwater samples from the Albuquerque outfalls were similar to the median concentrations in the stormwater samples from the six other Western U.S. metropolitan areas.

\section{References Cited}

Anderholm, S.K., Radell, M.J., and Richey, S.F., 1995, Waterquality assessment of the Rio Grande Valley study unit, Colorado, New Mexico, and Texas-Analysis of selected nutrient, suspended-sediment, and pesticide data: U.S. Geological Survey Water-Resources Investigations Report 94-4061, 203 p.

Buchanan, T.J., and Somers, W.P., 1982, Stage measurement at gaging stations: U.S. Geological Survey Techniques of Water-Resources Investigations, book 3, Applications of hydraulics, chap. A7, $28 \mathrm{p}$.

Carpenter, S.R., Caraco, N.F., Correl, R.W., Howarth, R.W., Sharpley, A.N., and Smith, V.H., 1998, Nonpoint pollution of surface waters with phosphorus and nitrogen: Ecological Applications, v. 8, no. 3, p. 559-568.

Davies, Laurie, and Gather, Ursala, 1993, The identification of multiple outliers: Journal of the American Statistical Association, v. 88, no. 423, p. 782-792.

Drever, J.I., 1997, The geochemistry of natural waters (3d ed.): Upper Saddle River, N.J., Prentice-Hall, 436 p.

Galloway, J.N., Aber, J.D., Erisman, J.W., Seitzinger, S.R., Howarth, R.W., Cowling, E.B., and Cosby, B.J., 2003, The nitrogen cascade: BioScience, v. 53, no. 4, p. 341-356.
Hem, J.D., 1992, Study and interpretation of the chemical characteristics of natural water (3d ed.): U.S. Geological Survey Water-Supply Paper 2254, 263 p.

Kjelstrom, L.C., 1995, Data for and adjusted regional regression models of volume and quality of urban stormwater in Boise and Garden City, Idaho, 1993-94: U.S. Geological Survey Water-Resources Investigations Report 95-4228, $36 \mathrm{p}$.

Langmuir, Donald, 1997, Aqueous environmental geochemistry: Upper Saddle River, N.J., Prentice-Hall, $600 \mathrm{p}$.

Lopes, T.J., Fossum, K.D., Phillips, J.V., and Monical, J.E., 1995, Statistical summary of selected physical, chemical, and microbial contaminants and estimates of constituent loads in urban stormwater in Maricopa County, Arizona: U.S. Geological Survey Water-Resources Investigations Report 94-4240, $62 \mathrm{p}$.

Mahler, B.J., Van Metre, P.C., Crane, J.L., Watts, A.W., Scoggins, M., and Spencer, E.S., 2012, Coal-tar-based pavement sealcoat and PAHs - Implications for the environment, human health, and stormwater management: Environmental Science and Technology, v. 46, no. 6, p. 3039-3045.

Maloney, T.J., ed., 2005, Quality management system, U.S. Geological Survey National Water Quality Laboratory: U.S. Geological Survey Open-File Report 2005-1263, version 1.3, 9 November 2005, chapters and appendixes variously paged.

Montgomery Watson Harza, 2004, Annual report for the Las Vegas Valley NPDES Municipal Stormwater Discharge Permit NPDES permit no. NV0021911: Las Vegas, Nevada, Montgomery Watson Harza, 425 p.

National Oceanic and Atmospheric Administration, 2013, NowData-NOAA Online Weather Data: National Oceanic and Atmospheric Administration, accessed February 16, 2013, at www.nws.noaa.gov/climate/xmacis.php?wfo=abq.

Parsons, Inc., 2005, Middle Rio Grande microbial source tracking assessment report: Parsons, Inc., prepared for New Mexico Environment Department, Albuquerque Metropolitan Arroyo Flood Control Authority, and Bernalillo County, variously paged.

Pitt, Robert, Maestre, Alex, Hyche, Hunter, and Togawa, Noboru, 2008, The updated National Stormwater Quality Database (NSQD), version 3: 2008 Water Environment Federation Technical Exposition and Conference, Chicago, Illinois, October 2008.

Stantec Consulting, 2009, Salt Lake City 2008 stormwater quality data technical report: Stantec Consulting, prepared for Utah Department of Transportation and Salt Lake County, $101 \mathrm{p}$. 
Stevens, M.R., and Slaughter, C.B., 2012, Summary and evaluation of the quality of stormwater in Denver, Colorado, 2006-2010: U.S. Geological Survey Open-File Report 2012-1052, 94 p.

Tate, K.W., Dahlgren, R.A., Singer, M.J., Allen-Diaz, B.H., and Atwill, E.R., 1999, Timing, frequency of sampling affect accuracy of water-quality monitoring: California Agriculture, v. 53, no. 6, p. 44-48.

Tchobanoglous, George, and Schroeder, Edward, 1985, Water quality: Reading, Massachusetts, Addison-Wesley Publishing Company, 768 p.

U.S. Census Bureau, 2013, Metropolitan areas ranked by population - 2010 U.S. Census Bureau data: Accessed December 20, 2013, at http://quickfacts.census.gov/qfd/ states.

U.S. Environmental Protection Agency, 1990, National Pollutant Discharge Elimination System permit applications regulations for stormwater discharges-Final rule: U.S. Federal Register, v. 55, no. 222, p. 47989-48091.

U.S. Environmental Protection Agency, 2014a, Polycyclic aromatic hydrocarbons (PAHs): U.S. Environmental Protection Agency (EPA) Fact Sheet, accessed January 2014 at http://www.epa.gov/osw/hazard/wastemin/minimize/ factshts/pahs.pdf.

U.S. Environmental Protection Agency, 2014b, Risk Assessment Guidance for Superfund (RAGS) Part A, Chapter 5: Accessed January 2014 at http://www.epa.gov/ oswer/riskassessment/ragsa/.

U.S. Environmental Protection Agency, 2014c, Pentachlorophenol and its use as a wood preservative: U.S. Environmental Protection Agency (EPA) Fact Sheet, accessed July 2, 2014, at http:/www.epa.gov/pesticides/ factsheets/chemicals/pentachlorophenol_main.htm.
U.S. Environmental Protection Agency, 2014d, Polychlorinated biphenyls (PCBs): U.S. Environmental Protection Agency (EPA) Fact Sheet, accessed July 21, 2014, at http://www.epa.gov/epawaste/hazard/tsd/pcbs/index.htm.

U.S. Geological Survey, variously dated, National field manual for the collection of water-quality data: U.S. Geological Survey Techniques of Water-Resources Investigations, book 9, chap. A1-A9. [Also available at http://water.usgs.gov/owq/FieldManual/.]

U.S. Geological Survey, 2006, U.S. Geological Survey Office of Surface Water Technical Memorandum 2006.01.01: U.S. Geological Survey, 29 p., accessed July 23, 2014, at http://water.usgs.gov/admin/memo/SW/ OSW_2006-01_Revised_02122010.pdf.

Veenhuis, J.E., 2003, Municipal stormwater sampling program, metropolitan area, Albuquerque, New MexicoSummary of sampling, 1992-2002: U.S. Geological Survey Fact Sheet 005-03, accessed January 2014 at http://pubs.usgs.gov/fs/2003/0005/report.pdf.

Wetzel, R.J., 2001, Limnology, lake and river ecosystems (3d ed.): San Diego, California, Academic Press, $1,006 \mathrm{p}$.

Wilcox, Ralph, 1997, Concentrations of selected trace elements and other constituents in the Rio Grande and in fish tissue in the vicinity of Albuquerque, New Mexico, 1994 to 1996: U.S. Geological Survey Open-File Report 97-667, $173 \mathrm{p}$.

Woodworth, M.T., and Connor, B.F., 2003, Results of the U.S. Geological Survey's analytical evaluation program for standard reference samples distributed in March 2003: U.S. Geological Survey Open-File Report 2003-261, 109 p. 


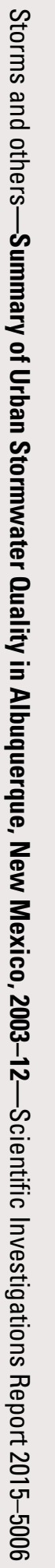

ISSN 2328-0328 (online) 